\title{
O EXAME CRIMINOLÓGICO E SUA VALORAÇÃO NO PROCESSO DE EXECUÇÃO PENAL
}

Orientador: Professor Titular Antonio Magalhães Gomes Filho

Faculdade de Direito da Universidade de São Paulo

São Paulo

2013 


\section{O EXAME CRIMINOLÓGICO E SUA VALORAÇÃO NO PROCESSO DE EXECUÇÃO PENAL}

Dissertação apresentada à Faculdade de Direito da Universidade de São Paulo como requisito parcial para a obtenção do título de Mestre em Direito Processual sob orientação do Professor Titular Antonio Magalhães Gomes Filho.

Faculdade de Direito da Universidade de São Paulo

São Paulo 


\section{AGRADECIMENTOS}

Agradeço ao Professor Antonio Magalhães Gomes Filho pela confiança e pelo apoio na escolha do tema, e, principalmente, pela orientação no desenvolvimento da presente dissertação de mestrado.

Aos Professores Gustavo Henrique Righi Ivahy Badaró e José Raul Gavião de Almeida pelas pertinentes críticas e sugestões feitas no exame de qualificação.

Aos Professores Antonio Scarance Fernandes, Marcos Alexandre Coelho Zilli, Maria Thereza Rocha de Assis de Moura, Maurício Zanoide de Moraes e Vicente Greco Filho pelas valiosas aulas ministradas no curso de Pós-Graduação.

Aos meus familiares e amigos pelo constante incentivo e por compreenderem a minha ausência em diversos momentos em virtude da dedicação aos estudos para a conclusão deste trabalho. 


\section{RESUMO}

O presente trabalho pretende abordar o processo de execução penal sob o enfoque da Lei $\mathrm{n}^{\circ}$ 7.210/84 e investigar se o exame criminológico realmente é hábil e imprescindível para fornecer subsídios para o julgador formar seu convencimento e tomar a decisão mais acertada no que concerne aos pedidos de progressão de regime e livramento condicional, de maneira a assegurar a efetividade da execução penal e ao mesmo tempo compatibilizar o interesse de reconquista da liberdade pelo condenado com a necessidade de se garantir a segurança social. Para isso, são feitas considerações acerca da Lei de Execução Penal, responsável por consolidar a natureza jurisdicional da execução penal, comentando-se o papel das partes e do juiz no processo executório. Na sequência, examina-se a disciplina da prova no âmbito da execução penal, em especial a prova pericial, uma vez que o exame criminológico é uma perícia. Após conceituar o exame criminológico e diferenciá-lo dos outros instrumentos de avaliação do apenado, comenta-se sobre a Lei $\mathrm{n}^{\mathrm{o}} 10.792 / 03$, a partir da qual o exame criminológico deixou de ser exigência para aferir o requisito subjetivo do sentenciado. Analisa-se a dificuldade do magistrado de valorar as provas técnicas, justamente por não dispor de conhecimentos técnicos para contestar as conclusões apresentadas pelos peritos e, assim, exercer algum tipo de controle sobre aquilo que é afirmado, e o risco da aceitação acrítica dos laudos pelos julgadores, dando, indiretamente, o poder da decisão para o perito.

Palavras-chave: execução penal - jurisdicionalização - exame criminológico - perícia valoração da prova. 


\begin{abstract}
This work intends to show the criminal enforcement process under the focus of Law $n^{\circ} 7.210 / 84$ and investigate whether the criminological examination is essential and able to offer elements to guide the judge to make a fair decision about the convict's requests, in order to ensure that the criminal enforcement process will be respected as well as it will make compatible the social reintegration of the convicted with the maintenance of a safe society. In this regard, comments about the Law of Penal Execution that gave the jurisdictional nature to the criminal enforcement will be done, describing the lawyer's acts, the district attorney's activities and the judge's work. Then the evidences system in the criminal enforcement process will be analyzed, paying particular attention to expert evidence, since the criminological examination is an expertise. After defining the criminological examination and comparing it with other assessment tools of the guilty party, it will be discussed the Law $\mathrm{n}^{\mathrm{o}} 10.792 / 03$ that dismiss the criminological examination to find out the subjective requirement of the prisoner. Finally it will be analyzed the difficulty of the judge to evaluate the technical evidences, because it is out of his knowledge and for this reason he does not have the tools to contest the explanations and/or conclusions given by experts, therefore he can not control the affirmations and there is the risk of acceptance of the reports by the judge without critical sense, indirectly giving the power of decision to the expert.
\end{abstract}

Key-words: Criminal enforcement - jurisdictional - criminological examination expertise - assessment of evidence 


\section{SUMÁRIO}

\section{INTRODUÇÃO}

\section{Capítulo I - SISTEMA PENITENCIÁRIO BRASILEIRO}

1. Estrutura dos estabelecimentos penais no Brasil ........................................... 12

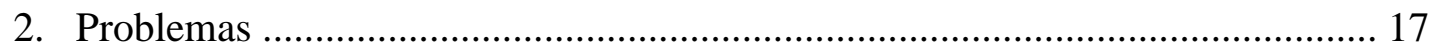

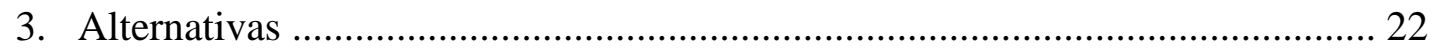

\section{Capítulo II - PROCESSO DE EXECUÇÃO PENAL}

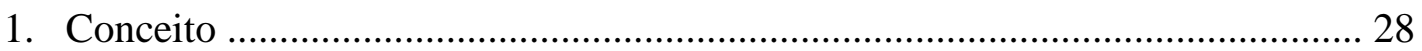

2. Advento da Lei de Execução Penal no Brasil...................................................... 30

2.1 Autonomia do processo de execução........................................................ 32

2.2 Jurisdicionalização da execução................................................................. 34

2.2.1 Sistema administrativo ................................................................ 35

2.2.2 Sistema misto........................................................................... 36

2.2.3 Sistema jurisdicional ......................................................... 36

3. O Ministério Público ........................................................................................... 41

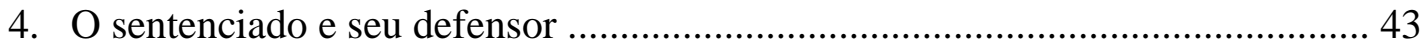

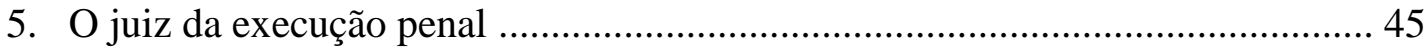

5.1 Atuação do Juiz: sistema inquisitório versus sistema acusatório................... 52

\section{Capítulo III - PROVA PERICIAL E EXECUÇÃO PENAL}

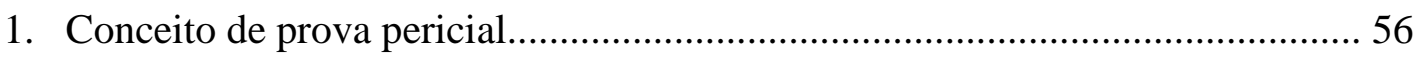

2. Produção de prova pericial na Lei de Execução Penal ...................................... 58

3. Ônus da prova na execução penal .................................................................... 60

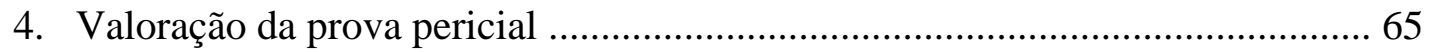

\section{Capítulo IV - O EXAME CRIMINOLÓGICO}

1. Institucionalização do exame criminológico ............................................... 70

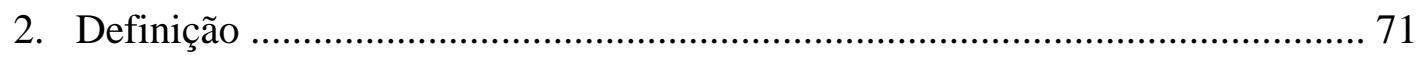

2.1 Tipos de exame criminológico ......................................................... 72

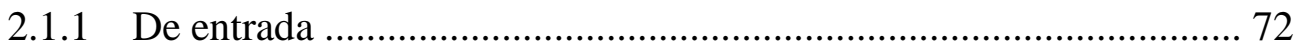


2.2 Objetivo 80

3. Diferenças entre o exame criminológico e os exames elaborados pela Comissão

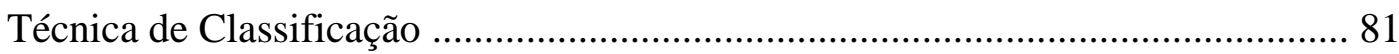

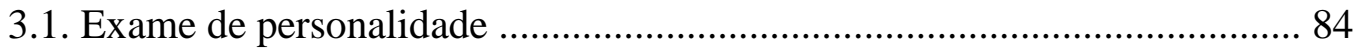

3.2. Pareceres da Comissão Técnica de Classificação ...................................... 85

\section{Capítulo V - O EXAME CRIMINOLÓGICO E A LEI 10.792/03}

1. Abolição do Exame Criminológico para instruir incidentes de execução.......... 88

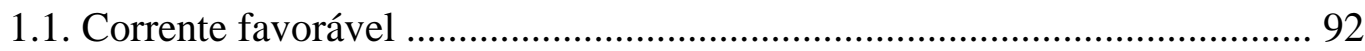

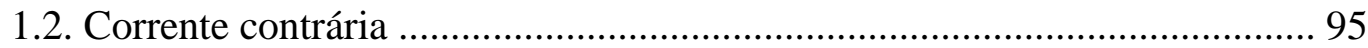

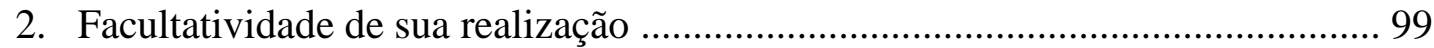

2.1.Entendimento Jurisprudencial ..................................................................... 102

\section{Capítulo VI - VALOR PROBATÓRIO DO EXAME CRIMINOLÓGICO}

1. Enquadramento do exame criminológico como prova pericial ....................... 104

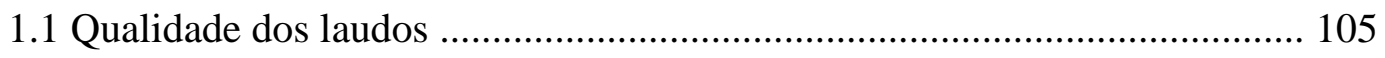

1.2 Necessidade da presença de médico psiquiatra .......................................... 111

1.3 Resoluções do Conselho Federal de Psicologia. ........................................... 113

1.3.1 Resolução 009/2010: Vedação ao psicólogo de realizar exame

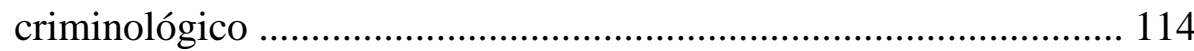

1.3.2 Suspensão dos efeitos da Resolução $\mathrm{n}^{\circ}$ 009/2010........................... 117

1.3.3 Resolução 012/2011: o fim dos prognósticos psicológicos.............. 117

1.4 Possibilidade das partes formularem quesitos aos peritos ......................... 119

1.5 Direito de permanecer em silêncio ou de se recusar a submeter ao exame 122

2. Adstrição do Juiz à conclusão do exame criminológico e ao atestado de conduta emitido pela autoridade penitenciária............................................................ 126

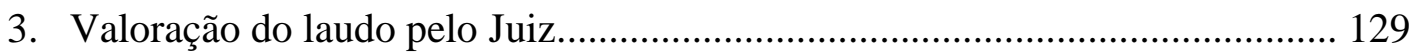




\section{INTRODUÇÃO}

A crise no sistema penitenciário brasileiro é fato notório. Nas últimas décadas, o crescimento da população carcerária, a falta de infraestrutura dos estabelecimentos prisionais, o surgimento e o crescimento de facções criminosas dentro dos presídios, e o descrédito na ideia de ressocialização da pena tem se acentuado cada vez mais.

Infelizmente, nunca se atribuiu muita atenção à execução penal, basta considerar que a Lei de Execução Penal tardou a ser editada, e, até hoje, muitos de seus comandos não tiveram aplicação efetiva. Sintetizando essa situação de descaso, René Ariel Dotti assinala que "a experiência tem demonstrado ao longo dos anos que a execução penal é um vasto espaço de terras devolutas, um quadro de naturezas mortas, um arquipélago de dificuldades e um território sitiado pela violência, quando não pela indiferença tradicional do Poder Público em relação ao problema geral da insegurança coletiva e individual."1 .

O estudo da execução penal é extremamente relevante e instigante, pois devido ao aumento e ao aprimoramento da criminalidade, há uma grande cobrança por parte da sociedade no sentido de aumentar penas, endurecer regimes, relativizar os direitos dos condenados, enfim, medidas que visam dar a sensação de maior segurança à coletividade. Deve-se, no entanto, tomar cautela com as reformas pontuais, que, diga-se, são corriqueiras no ordenamento jurídico brasileiro, sob pena de comprometer toda a coerência do sistema.

Destarte, na expressão de Antonio Scarance Fernandes, "há, portanto, grande interesse em se avançar na discussão da disfunção do sistema, da crise da execução penal, da inadequação de determinadas opções do legislador." ${ }^{2}$.

O presente trabalho pretende analisar a realização do exame criminológico para fins de aquisição de benefícios durante o cumprimento da pena, tais como progressão de regime, livramento condicional, indulto e comutação de penas e a sua importância para a formação da convicção do juiz para deferir ou indeferir os pleitos, em face da alteração legislativa advinda da Lei $\mathrm{n}^{\circ} 10.792 / 2003$.

A principal questão do estudo a ser desenvolvido não é exatamente a obrigatoriedade da realização do exame criminológico, mas sim a sua apreciação pelo magistrado. E mais, atestar se o aludido exame realmente é hábil e imprescindível para

\footnotetext{
1 ReNÉ ARIEL DotTI, A lei de execução penal: perspectivas fundamentais, Revista de Política Criminal e Penitenciária, v.1,jan/jun 1988, p.207.

2 ANTONIO SCARANCE FeRNANDES, Execução penal: aspectos jurídicos, Revista CEJ.v.3.n.7, abr. 1999, p.69.
} 
fornecer subsídios técnicos para o julgador formar seu convencimento e tomar a decisão mais acertada no que concerne aos benefícios, de maneira a assegurar a efetividade da execução penal e ao mesmo tempo compatibilizar o interesse de reconquista da liberdade pelo condenado com a necessidade de se garantir a segurança social.

Em razão do caráter interdisciplinar da execução penal e do exame criminológico, para melhor elucidação das questões atinentes a este instituto jurídico, cujo estudo se propõe, foi necessário transpor os limites da área processual, área de concentração elegida, para buscar subsídios em outras áreas, como por exemplo, Criminologia e Direito Penal.

Inicialmente, se delineará a estrutura dos estabelecimentos penais da forma descrita pela Lei de Execução Penal, com o objetivo de introduzir à pesquisa o princípio da individualização da pena na fase executória e a ideia de sistema progressivo.

Em seguida, será analisado o sistema carcerário brasileiro na contemporaneidade, levando-se em consideração os problemas emergentes da falta de infraestrutura, do desprezo estatal pela fase do cumprimento da pena, da complexa criminalidade atual que fomenta a criação e o fortalecimento de organizações criminosas no interior dos estabelecimentos prisionais.

O Capítulo II será dedicado à discussão acerca da natureza jurídica da execução penal, cotejando-se as principais as correntes sobre a questão. Na sequência, versar-se-á sobre a autonomia científica do Direito de Execução Penal, a sua nomenclatura e a interação com os outros ramos do ordenamento jurídico.

Considerando a execução da pena como atividade jurisdicionalizada, pretende-se abordar a mudança de ótica quanto à figura do apenado, que deixa de ser simples detentor de obrigações e deveres para se tornar titular de direitos subjetivos e faculdades, assegurando-lhe a eficácia de seus direitos e garantias fundamentais não atingidos pela sentença.

Em razão do reconhecimento da existência de uma relação jurídico processual, o encarcerado passa a ser sujeito de direitos exigíveis do Estado, fato que contribuiu para a instituição de um juiz especializado para gerir o processo de execução. O juiz da execução passa a não ser mais visto como um mero aplicador da sentença condenatória penal, mas sim como colaborador para garantir a ordem jurídica, promovendo a observância dos direitos fundamentais e, assim, contribuir para efetivação da Justiça. 
Neste contexto, será esquadrinhada a função do juiz para a efetivação dos direitos subjetivos reconhecidos do apenado a fim de demonstrar a importância de atuação engajada do magistrado na fase do cumprimento da pena.

Na sequência, será examinada a disciplina da prova no âmbito da execução penal, em especial a prova pericial, uma vez que o exame criminológico é uma perícia. No que tange a valoração da prova pericial, deverá ser enfrentado a problemática da recepção acrítica dos laudos periciais e a dificuldade de sua refutação pelo juiz pelas mesmas razões pelas quais se determinou sua produção: a falta de conhecimentos técnicos sobre determinado assunto não jurídico; refletindo-se como a previsão do assistente técnico pode ajudar a contornar este obstáculo e se isso pode ser aplicado em sede de execução penal.

Outrossim, serão apresentados os instrumentos de avaliação do condenado previstos pela Lei de Execução Penal (o exame de personalidade, o exame criminológico e parecer da Comissão Técnica de Classificação). Será feita a distinção conceitual dos institutos, pois grande parte das dificuldades encontradas pelos operadores do direito no tratamento da matéria está no emprego errôneo de certas expressões, misturando-se nomenclaturas e terminologias, o que dificulta o esclarecimento acerca da natureza jurídica dos exames, fomentando incertezas, equívocos e contradições.

Com relação ao exame criminológico, há duas modalidades, mas a ênfase será dada ao exame criminológico destinado a instruir incidentes de execução, ou seja, à avaliação do requisito subjetivo nas penas privativas de liberdade por ocasião do cumprimento do lapso temporal para concessão de benefícios.

O exame do mérito do reeducando para obtenção de benefícios na execução penal, sempre foi questão tormentosa, porém, após a edição Lei $\mathrm{n}^{\circ} 10.792 / 03$, que alterou a redação do artigo 112 da Lei de Execução Penal, a fim de prever não ser mais exigível o exame criminológico para instruir o pedido de progressão de regime prisional, aplicando-se o previsto também aos outros benefícios, a questão ganhou novo fôlego.

O assunto sobre o valor dos laudos criminológicos para a formação da convicção do juiz sempre foi polêmico, contudo, depois da Lei $n^{\circ} 10.792 / 2003$, a controvérsia tem se tornado mais acirrada, ensejando a propositura de diversos recursos judiciais que questionam a matéria, forçando o Judiciário a se manifestar sobre a alteração legislativa. A edição da Súmula Vinculante $n^{\circ} 26$ e da Súmula 439 do Superior Tribunal de Justiça demonstram a importância do tema, e impulsionam o debate, na medida em que 
representam o reconhecimento pelos tribunais superiores da possibilidade da realização do exame criminológico em incidentes de execução mediante decisão fundamentada.

O desaparelhamento do sistema penitenciário, a morosidade e superficialidade dos laudos, abalam a confiabilidade do exame enquanto prova. Muitos são os desafios envolvendo o exame criminológico dentre eles a divergência quanto à estrutura, ao plano, às peças que o integram, esboçando a ausência de método, a inconsistência científica e a dificuldade de se estabelecer um parâmetro de qualidade nos laudos criminológicos. Raramente existe a participação de psiquiatra e a atuação do psicólogo na elaboração dos laudos também foi discutida e revista pelo Conselho Federal de Psicologia.

Por fim, considerando que o tema escolhido como alvo da presente dissertação de mestrado refere-se à exigência do exame criminológico para a aferição do mérito do sentenciado que pleiteia benefícios na fase executória da pena e seu valor probatório para a formação do convencimento do juiz, pretende-se explorar também a temática do exame criminológico como instrumento introdutor do discurso da 'verdade' no processo de execução, e como isto comprometeria a avaliação da prova a e transferiria a carga decisória das pretensões do apenado para as mãos dos peritos. Tentar-se-á administrar a incongruência consubstanciada na exigência do exame criminológico para embasar a decisão judicial, considerando que, ao mesmo tempo em que se alega que ele é essencial para garantir uma decisão com a devida motivação, percebe-se que sua presença fomenta decisões de aderência pelos juízes que apenas se reportam à conclusão do laudo, a homologam na íntegra, sem sequer citar dados do exame ou fatos da execução que corroboram ou não com o que ficou atestado para melhor fundamentar a decisão. 


\section{CAPÍTULO I - SISTEMA PENITENCIÁRIO BRASILEIRO}

\section{Estrutura dos estabelecimentos penais no Brasil}

As Regras Mínimas da Organização das Nações Unidas para o Tratamento de Reclusos de 1955 , item $\mathrm{n}^{\circ} 8$, preconizam que presos pertencentes a categorias diversas deverão ser alojados em diferentes estabelecimentos.

Em igual diretriz, a Constituição Federal de 1988 em seu artigo 5º inciso XLVIII, dispõe que a pena será cumprida em estabelecimentos distintos de acordo com a natureza do delito, a idade e o sexo do apenado.

A importância de se diferenciar o local de recolhimento está baseada na individualização do tratamento correspondente a ser aplicado e já estava presente na Lei de Execução Penal, promulgada poucos anos antes da Constituição Federal, sendo certo, evidentemente, que com advento da nova Constituição houve a consagração deste entendimento como direito e garantia fundamental do indivíduo, fortalecendo-o.

A redação do artigo 82 da Lei de Execução Penal preconiza que os estabelecimentos penais destinam-se ao condenado, ao submetido à medida de segurança, ao preso provisório e ao egresso.

Extrai-se do item 94 da Exposição de Motivos da Lei de Execução Penal que os estabelecimentos penais compreendem: $1^{\circ}$ ) a Penitenciária, destinada ao condenado à reclusão, a ser cumprida em regime fechado; $2^{\circ}$ ) a Colônia Agrícola, Industrial ou similar, reservada para a execução da pena de reclusão ou detenção em regime semiaberto; $3^{\circ}$ ) a Casa do Albergado, prevista para acolher os condenados à pena privativa da liberdade em regime aberto e à pena de limitação de fim de semana; $4^{\circ}$ ) o Centro de Observação, onde serão realizados os exames gerais e o criminológico; $5^{\circ}$ ) o Hospital de Custódia e Tratamento Psiquiátrico, que se destina aos doentes mentais, aos portadores de desenvolvimento mental incompleto ou retardado e aos que manifestam perturbação das faculdades mentais; e, $6^{\circ}$ ) a Cadeia Pública, para onde devem ser remetidos os presos provisórios (prisão em flagrante, prisão temporária, prisão preventiva ou em razão da pronúncia $^{3}$ ) e, finalmente, os condenados enquanto não transitar em julgado a sentença ${ }^{4}$.

\footnotetext{
${ }^{3}$ Pela nova sistemática procedimental introduzida pela Lei n. ${ }^{\circ} 11.689 / 2008$ a prisão do réu pronunciado não é mais obrigatória, como, de regra, previa o regime até então em vigor.

${ }^{4}$ A Lei n. ${ }^{\circ} 11.689 / 2008$ revogou o artigo 594, do CPP, não se exigindo mais o recolhimento à prisão para apelar.
} 
A separação entre os tipos de presos se justifica na diversidade dos títulos em que se lastreia a prisão, bem como para facilitar o tratamento penitenciário a ser conferido no estabelecimento penal.

As mulheres deverão ser apartadas dos condenados masculinos, sendo recolhidas em estabelecimento próprio e adequado à sua condição pessoal. Tal regra visa assegurar a integridade física, psíquica e moral das presas, evitando a promiscuidade e as violências sexuais, infelizmente, tão comuns no cárcere.

Ao idoso também é garantindo o cumprimento de pena em estabelecimento adequado com sua condição pessoal de maior vulnerabilidade.

Nos termos do artigo 84 da Lei de Execução Penal, os presos provisórios deveriam ficar separados de condenados definitivos. A separação entre presos provisórios e condenados por sentença transitada em julgado decorre também de comando presente nas Regras Mínimas para o Tratamento de Reclusos da ONU (nº $8-b)$.

Leciona Guilherme de Souza Nucci que "não se pode conceber que condenados definitivos compartilhem espaços conjuntos com presos provisórios. Estes estão detidos por medida de cautela, sem apuração de culpa formada, podendo deixar o cárcere a qualquer momento, inclusive em decorrência de absolvição. Se forem mantidos juntamente com sentenciados, mormente perigosos tendem a absorver defeitos e lições errôneas, passíveis de lhes transformar a vida quando deixarem o cárcere. Além disso, estão sujeitos a violências de toda ordem, tornando a prisão cautelar uma medida extremamente amarga e, até mesmo, cruel. ${ }^{5}$ ".

A Cadeia Pública, consoante a Exposição de Motivos da Lei de Execução Penal, foi idealizada para ser o estabelecimento que acolheria os presos provisórios, mas, na prática, os estabelecimentos responsáveis pela guarda da maioria desses presos são os Centros de Detenção Provisória (CDP).

A escalada da criminalidade e a preferência pela prisão cautelar pelos juízos contribuem para o aumento do número de presos provisórios no país, muito embora, haja esforços, a citar a edição da Lei $\mathrm{n}^{0}$ 12.403/2011, para contornar a cultura do aprisionamento, fornecendo outras medidas cautelares em substituição à prisão. Além disso, o número de presos provisórios é agravado pela demora do Poder Judiciário em movimentar os processos. Insta esclarecer que quando a Lei de Execução Penal foi

\footnotetext{
${ }^{5}$ GUILHERME DE SouZA NuCCI, Leis Penais e processuais penais comentadas, $2^{\mathrm{a}}$ ed., São Paulo: RT, 2007, p. 477.
} 
promulgada não se concebia a possibilidade de execução provisória da pena ${ }^{6}$. No entanto, dada a atual conjectura do sistema carcerário e do Poder Judiciário, em que o julgamento de recursos demora demasiadamente, podendo o réu esperar anos preso aguardando a sentença transitar em julgado, a doutrina e a jurisprudência encamparam a ideia de execução provisória ${ }^{7}$.

Diante do contingente de presos provisórios, a falta de vagas tornou-se uma constante, fomentando a existência de alojamentos improvisados em dependências de cadeias públicas e distritos policiais.

O Poder Executivo para contornar esse cenário iniciou a construção e instalação de estabelecimentos penais maiores que uma cadeia pública, com estrutura de presídio destinado somente aos presos provisórios. São os Centros de Detenção Provisória.

A Lei de Execução Penal, em seu art. 84, $§ 1^{\circ}$, dispõe também que deveria haver uma separação entre réus primários e reincidentes quanto ao local de cumprimento de pena, o que na prática não se concretiza.

A lógica dessa segregação, nas palavras de Mirabete, estaria no fato de que "aquele que delinquiu pela primeira vez, eventualmente em uma situação excepcional, tem melhores condições para responder ao processo de reabilitação social do que o reincidente, muitas vezes criminoso habitual e, por sua vida marcadamente anti-social mais refratário à readaptação pretendida com a execução da pena. Evitam-se o mais que possível contágio e as nocivas influências do condenado contumaz em relação ao primário, que os pode levar à corrupção, a uma fácil integração à "subcultura carcerária" e às maiores dificuldades no caminho da reinserção social. ${ }^{8}$ ".

\footnotetext{
${ }^{6}$ Considerando o contexto político em que a Lei de Execução Penal foi elaborada, apenas poucos anos antes da Constituição de 1988, a ideia de uma execução provisória ou antecipada colidia com o sistema que se visava instaurar, uma vez que violaria os direitos fundamentais do acusado, principalmente a presunção de inocência e o devido processo legal, impondo ao acusado a execução de uma pena quando ainda não havia sido declarada judicialmente a certeza da prática da infração penal por ele, ante a falta do trânsito em julgado da sentença.

${ }^{7}$ Nesse rumo, explica SIDNEI AgOstinho BENETI, que “o sistema processual tem de oferecer solução para casos como o do acusado preso que, sem recurso da acusação, recorra da condenação e, durante o processamento do recurso, preencha os requisitos de tempo e de mérito para a progressão no regime prisional ou para o trabalho, de que lhe deriva o importante direito à remição, e semelhantes direitos típicos da execução da pena. A vicissitude processual do decurso do tempo necessário ao julgamento do recurso, interposto pelo acusado como exercício de direito seu, vem a determinar-lhe prejuízo decorrente exatamente do fato do exercício do direito ao duplo grau de jurisdição, configurando-se, em verdade, verdadeira cilada processual à margem da legislação repressiva, em assunto, aliás, tipicamente de direito material, como o dos regimes prisionais." (Execução penal, São Paulo: Saraiva,1996,p.89.)

${ }^{8}$ JULio FABBRINi MIRABETE, Execução Penal, $11^{\mathrm{a}}$ ed.,SãoPaulo: Atlas, 2008 p. 254-255.
} 
A penitenciária se amoldaria aos condenados com maior índice de periculosidade, aqueles que foram condenados à pena de reclusão no regime mais severo, o fechado, e por isso demandariam maior vigilância por parte do Estado.

Por razões de segurança as penitenciárias são construídas em locais afastados dos centros urbanos. A distância dos grandes centros deve ser o suficiente para evitar que eventuais motins ou fugas atinjam a comunidade, porém, o estabelecimento não deve ser tão longínquo a ponto de inviabilizar a visitação aos presos, uma vez que é essencial a manutenção do contado interpessoal com familiares, amigos, conhecidos, etc., para o processo de reinserção social.

O sistema progressivo é ponto basilar da execução penal, assim, para a correta evolução do apenado é necessário que após passar certo tempo na prisão de segurança máxima, ele seja inserido em um estabelecimento em que ainda haja vigilância, porém, mais amena, a fim de possibilitar a constatação do senso de responsabilidade do detento.

As colônias agrícolas, industrial ou similar, tal qual previstas no artigo 91, da Lei de Execução Penal destinam-se ao cumprimento de pena em regime semiaberto. São estabelecimentos aptos para receber o preso em transição do regime mais severo para o intermediário.

Essa passagem é fundamental para o sucesso do sistema progressivo, afinal “a transição para um regime semiaberto é necessária, evidentemente, pois que esse condenado não tem aptidão, desde logo, para ser transferido para o regime aberto. Há forte estímulo para a fuga quanto ao condenado a longos anos de pena, ainda que seja ele portador de condições que o tornariam apto para um regime menos rigoroso. O regime semiaberto, portanto, é, nessa hipótese, uma transição para o regime aberto, no processo de reinserção social do condenado. ${ }^{9}$, .

As colônias não são somente estabelecimentos de transição, mas também são os estabelecimentos que deverão receber os apenados às penas de média duração que foram condenados ao cumprimento de pena em regime inicial semiaberto.

Diferentemente das penitenciárias, onde os presos são trancados em celas, e só saem delas em horários pré-estabelecidos, sempre acompanhados por agentes de segurança ${ }^{10}$,

\footnotetext{
${ }^{9}$ Idem, p. 273.

${ }^{10} \mathrm{Na}$ exposição de MANOEL PEDRO PiMENTEL, a prisão de segurança máxima é aquela em que o estabelecimento penal se situa no interior de fortes muralhas ou de intransponíveis alambrados, contando com celas individuais, permanecendo os sentenciados sob constante vigilância. Os internos, salvo autorizações especiais, não podem transitar pelo interior do presídio livremente, devendo estar sempre acompanhados de escolta. Mesmo quando transitam para as salas de aulas ou para os pavilhões de trabalho
} 
nos estabelecimentos de semiaberto, os presos podem movimentar-se com relativa liberdade, a guarda de segurança não é fortemente armada e a vigilância é mais amena, dado que a finalidade dessas unidades funda-se na apuração do senso de responsabilidade do condenado que deve ser estimulado e reconhecido.

Justamente por ser a vigilância reduzida, confiando-se no homem, que deve assumir a responsabilidade de não abandonar o local, para esses estabelecimentos intermediários devem ser enviados somente detentos devidamente preparados para gozar da semiliberdade. $^{11}$

Aos presos que cumprem pena em regime semiaberto são permitidas as saídas temporárias, que ocorrem em datas pré-estabelecidas com periodicidade. A ideia é permitir a retomada paulatina do contato com sociedade. No ensinamento de René Ariel Dotti, "as saídas temporárias, cuja maior justificação dogmática está em preparar adequadamente o retorno à liberdade e reduzir o caráter de confinamento absoluto da pena privativa de liberdade, caracterizam uma etapa da forma progressiva da execução e podem ser consideradas como a sala de espera do livramento condicional.". ${ }^{12}$

O terceiro estabelecimento penal descrito na Exposição de Motivos da Lei de Execução Penal é a Casa de Albergado, que também pode ser denominada prisão albergue e é uma modalidade de estabelecimento prisional destinada para o recolhimento noturno, com segurança mínima. De acordo com a legislação, deverá situar-se em centro urbano, separada dos demais estabelecimentos, caracterizando-se pela ausência de obstáculos físicos contra a fuga. Além de abrigar os condenados à pena privativa da liberdade em regime aberto, a Casa do Albergado também deve acolher os apenados com a limitação de fim de semana. Esse estabelecimento deve conter aposentos para acomodar os presos e local apropriado para cursos e palestras.

Em síntese, o condenado trabalha, estuda dedica-se a outras atividades lícitas fora do estabelecimento durante o dia, sem escolta ou vigilância, e recolhe-se à Casa do Albergado à noite e nos dias em que não deva exercer tais misteres. ${ }^{13}$ "A grande vantagem da prisão aberta é permitir que o reeducando faça uma experiência de liberdade concreta, e não

ou de saúde, é imprescindível a presença de escolta. É obrigatório o uso de uniformes, as visitas são limitadas, sendo frequentes os castigos disciplinares. (Sistemas penitenciários, Revista dos Tribunais n.639, jan. 1989, p.270.)

${ }^{11}$ Idem, p. 270.

${ }^{12}$ ReNÉ ARIEL DotTI, A crise da execução penal e o papel do Ministério Público, Justitia 47(129), abr./jun. 1985, p.52.

${ }^{13}$ JuLIO FABBRINI MIRABETE, Execução Penal, cit., p. 276. 
apenas simulada, pois tem oportunidade de viver e de trabalhar como um homem livre, embora ainda esteja cumprindo pena.". 14

Na prática, a Casa do Albergado é ilustre desconhecida de muitas Comarcas, como, por exemplo, da cidade de São Paulo, onde há um número elevado de presos inseridos no regime aberto. ${ }^{15}$

O próximo estabelecimento penal a ser analisado é o Centro de Observação. Trata-se do estabelecimento penal responsável pela realização de exames gerais e o criminológico. De acordo com a Lei de Execução Penal, estes centros deverão ser instalados em unidade autônoma ou em anexo da unidade prisional.

A função do Centro de Observação é elaborar exames que auxiliem na formulação de programa individualizado de cumprimento de pena. Os resultados obtidos pelo Centro de Observação deverão ser encaminhados para a Comissão Técnica de Classificação, encarregada de classificar o condenado no estabelecimento no qual funcione, pois diferentemente do Centro de Observação, a Comissão Técnica de Classificação é instalada na própria unidade prisional em que o apenado cumpre pena, para elaborar o programa de acompanhamento.

Já antevendo a dificuldade e consequente carência de Centros de Observação, a lei dispõe que, em sua falta, os exames serão realizados pela Comissão Técnica de Classificação.

No estado de São Paulo, os Centros de Observação Criminológica foram extintos pelo Decreto $\mathrm{n}^{\mathrm{o}}$ 46.483/2002, sendo substituídos pelo Núcleo de Observação Criminológica, órgão da Secretaria da Administração Penitenciária.

Por fim, tem-se o Hospital de Custódia e Tratamento Psiquiátrico que, sucintamente, é o estabelecimento penal destinado ao cumprimento de medida de segurança, não se tecendo maiores comentários a respeito deste estabelecimento, eis que alheio ao tema objeto desta dissertação.

\section{Problemas}

Nas últimas décadas, problemas como a superlotação, a falta de aparelhamento nos estabelecimentos prisionais, o surgimento e crescimento de facções criminosas dentro dos

\footnotetext{
${ }^{14}$ MANOEL PEDRO PIMENTEL, Sistemas penitenciários... cit., p.270.

${ }^{15}$ GuILHERME DE SOUZA NuCCI, Leis penais... cit., p.482.
} 
presídios tem se acentuado cada vez mais, redundando em uma inegável crise no sistema penitenciário brasileiro.

Não só no Brasil, mas em vários países, o sistema carcerário padece cada vez mais, a superpopulação, a violência (física, psíquica e sexual), males que fazem dos cárceres ambientes de estigma, de inadaptação, de metástase social, onde se avilta a personalidade, se destroça a privacidade, se vulnera a dignidade, se destrói a identidade social, se acentua a insegurança, em exercício contínuo de despotismo de degradação por parte do pessoal administrativo e dos líderes da massa carcerária. ${ }^{16}$

A falta de interesse social pelos problemas do cárcere é gritante e contribui expressivamente para agravar ainda mais a situação. A sociedade tem interesse na punição, assim, só presta atenção até o indivíduo ser condenado. Após a condenação, disseminado o sentimento de que a Justiça foi feita, a coletividade simplesmente se esquece daquele apenado, pouco se importando com o que lhe acontecerá.

$\mathrm{Na}$ atual quadra de criminalidade acentuada, a sociedade só quer a punição maciça, mas não se importa como essa pena será executada. Daí o tão intenso debate sobre os direitos humanos dos apenados, que para muitos cidadãos comuns é um disparate.

Este desinteresse não acomete só o cidadão comum, mas também atinge o Estado, que pouco investe na execução penal. Quando muito somente se preocupa com a construção em larga escala de presídios ${ }^{17}$, ao invés de intensificar políticas públicas que permitam a prevenção, a recuperação e a reinserção social dos cativos.

O descaso do Poder Público que vem negligenciando regras básicas consistentes em dar condições suficientes ao sistema penitenciário brasileiro, seja no sentido humano, seja no sentido material, reflete-se em estabelecimentos superlotados, cadeias fétidas, onde não há respeito à integridade física, psicológica e moral do preso. As prisões da forma como se encontram hoje, não reeducam, não recuperaram, somente aprimoram a criminalidade e elevam as taxas de reincidência.

\footnotetext{
${ }^{16}$ CÉSAR BARros LeAL, A execução penal na América latina e no Caribe: realidade e desafios, Revista Brasileira de Ciências Criminais v. 12. n. 50, set./out.2004,p. 125.

${ }^{17}$ Com relação a este ponto, ALESSANDRA TEIXEIRA esclarece que a escalada da população carcerária a partir de 1995, resultado das legislações criminais de urgência e da prevalência das políticas criminais conservadoras empreendidas a partir da década de 90, dentre elas a edição da lei dos crimes hediondos com a previsão do cumprimento de pena em regime integralmente fechado, optando-se pelo encarceramento em detrimento do ideal ressocializador, se passou a assistir, sobretudo a partir de 1998, com a liberação de recursos federais e estaduais para a instalação de novas unidades do Estado, numa política de interiorização do cumprimento da pena, ou seja, de transferência dos presos da Capital para penitenciárias no interior de Estado. (Do sujeito de direito ao Estado de Exceção: o percurso contemporâneo do sistema penitenciário brasileiro. Dissertação de mestrado FFLCH/USP, 2006, p.139-140)
} 
O sistema penitenciário brasileiro apresenta diversos problemas, dentre os mais expressivos pode-se citar a superpopulação, os motins e o poder paralelo dentro dos presídios. Além disso, não há trabalho, e sim o fomento ao ócio, não há atendimento jurídico que satisfaça a demanda, não há cuidados para com a saúde e a higiene, em suma, inexiste assistência de qualquer ordem.

Sobre os principais problemas enfrentados na execução penal, Maria Thereza Rocha de Assis Moura se reporta a relatório elaborado pela Anistia Internacional esclarecendo que as sérias violações aos direitos dos presos são, em parte, resultado de problemas estruturais e administrativos do sistema penal brasileiro: longos períodos de encarceramento; condenados sob a custódia da polícia, e não em instituições penais; insuficiência de pessoal carcerário e de treinamento; assistência médica inadequada; escassez de assistência jurídica gratuita para os pobres; recursos humanos insuficientes e de baixa qualidade; corrupção e má administração. ${ }^{18}$

Na prática, o que se vê é a deturpação absoluta do aparato normativo: a) presos definitivos em estabelecimentos destinados a presos provisórios; b) presos de regimes distintos submetidos ao mesmo tratamento; c) ausência de condições para o trabalho; d) inexistência de estabelecimentos prisionais de características industrial (semiaberto); e) insuficiência de colônias agrícolas; f) corrupção; g) ausência de classificação, individualização e assistência afetivas. ${ }^{19}$

Em 1988, ano de promulgação da Constituição Federal e poucos anos após o advento da Lei de Execução Penal, René Ariel Dotti já alertava que o tormentoso e permanente desafio da superlotação carcerária iria agravar ainda mais a situação caótica dos estabelecimentos penais. ${ }^{20}$

Hoje há um contingente prisional muito além da capacidade dos estabelecimentos existentes, que em sua maioria estão em situação precária, não oferecendo as mínimas condições necessárias para um cumprimento humano da pena.

O excesso populacional nos cárceres não está ligado unicamente com o aumento exponencial da criminalidade que se observa na atual quadra, mas também tem como causa (i) a morosidade da Justiça; (ii) o uso demasiado das prisões cautelares, considerando que

\footnotetext{
${ }^{18}$ MARIA Thereza Rocha DE ASSIS MourA, Execução penal e falência do sistema carcerário, Boletim IBCCRIM n.83 (esp.),out. 1999, p. 10-11.

${ }^{19}$ RoDRIGO IENNACO, A supressão do exame criminológico como (mais um) obstáculo à efetividade da execução penal: revisitando o paradigma behaviorista, Revista dos Tribunais n.838, ago. 2005, p. 453.

${ }^{20}$ RENÉ ARIEL DOTTI, A lei de execução penal: perspectivas fundamentais, Revista de Política Criminal e Penitenciária v.1, jan./jun. 1988, p.201.
} 
grande parte da massa carcerária é composta de presos provisórios que sequer foram sentenciados ou cujos processos estão pendentes do julgamento de recursos; (iii) a preferência maciça pela aplicação de penas privativas de liberdade quando poderiam ser cabíveis penas alternativas; (iv) a fixação de longas penas, acreditando-se que punir mais seja punir melhor e (v) a insuficiência de vagas.

No que tange a falta de vagas, o problema não atinge somente os sentenciados novatos, que iniciarão o cumprimento da pena, mas também os apenados já inseridos no sistema e beneficiados como progressão de regime.

Tem sido frequente a colocação ou a manutenção do condenado em regime mais rigoroso por falta de vagas em estabelecimento adequado compatível com o regime fixado em sentença ou com o qual o cativo foi progredido.

A superpopulação carcerária revela-se ainda um problema de saúde pública, pois não é incomum verificar-se nos presídios altas taxas de doenças respiratórias, tais como tuberculose, e alta incidência da AIDS. Com efeito, a aglomeração incentiva a propagação de doenças.

Outro desafio a ser enfrentado é o surgimento de facções criminosas no interior dos presídios. A gênese das organizações criminosas nos cárceres brasileiros estaria umbilicalmente implicada nas políticas penitenciárias que passariam a ser empreendidas, a nível nacional, a partir dos anos 90, fortalecendo-se na esteira da ausência ou da insidiosa presença do Estado nos estabelecimentos penais. ${ }^{21}$

A Lei dos Crimes Hediondos é apontada como um dos fatores que favoreceram a criação dessas organizações criminosas dentro dos presídios, pois elegia como regime único de cumprimento de pena o regime fechado e vedava o direito à progressão a um regime mais brando. A lei implicou uma concentração maior de indivíduos nos presídios de regime fechado, indivíduos estes considerados criminosos de alta periculosidade, e por maior curso de tempo, elevando as taxas de encarceramento, fato que gerou uma ordem de instabilidades e novos arranjos e distribuições de poder no interior do sistema.

A instauração de um poder paralelo exercido por grupos de presos articulados e organizados é preocupante. A existência de um código de conduta ditado por estes grupos a ser observado pelos demais presos inviabiliza a manutenção da autoridade, da ordem e da disciplina dos estabelecimentos prisionais pelo poder formal instituído, não sendo incomum a deflagração de motins e rebeliões.

${ }^{21}$ Alessandra TeIXEIRA, Do sujeito... cit., p.87-88. 
Com mais frequência são noticiados pela imprensa atos de domínio por grupos de presos nos estabelecimentos penais, constatando-se que os chefes do crime organizado exercem a autoridade e ditam suas próprias pautas não escritas de comportamento, aplicam sanções, decidem quem deve morrer ou viver, ao mesmo tempo em que vendem produtos e serviços (alimentos, bebidas, armas, proteção etc.) e comandam a extorsão, o narcotráfico e o mercado do sexo. ${ }^{22}$

Não se pode perder de vista que esses grupos paraestatais só surgem e se mantêm por conta do vazio deixado da autoridade legítima ${ }^{23}$, contando-se muitas vezes com a conveniência dos agentes prisionais, e da desordem que disso provém, e estimula o tráfico de influências, a disputa pelo controle, as mortes anunciadas, os massacres que enchem as telas dos meios de comunicação social. ${ }^{24}$

A situação caótica em que se encontra, de modo geral, o sistema penitenciário brasileiro vem sendo agravada ante a resistência do Estado em investir na implementação dos comandos da Lei de Execução Penal.

O investimento necessário para o desenvolvimento da atividade estatal em questão, pode parecer elevado, mas não é nada quando comparado com o prejuízo causado pela atuação de grupos do crime organizado que de dentro dos presídios comandam crimes, ou pela não recuperação dos sentenciados, que postos em liberdade reincidem na vida delitiva, trazendo mais danos à sociedade.

Sobre esse ponto, Guilherme de Souza Nucci alerta que "o dinheiro que o Estado diz poupar na fase do cumprimento da pena, com certeza, vai gastar no futuro, comprando mais armas para a polícia, aumentando o número de vagas nos cárceres e elevando o contingente de policiais. Afinal, se o preso for ilusoriamente reeducado, poderá tornar à liberdade em situação piorada e a criminalidade somente experimentará incremento.". ${ }^{25}$

Com efeito, nota-se que o sistema penitenciário vivencia um momento muito dramático, necessitando urgentemente de investimentos, não só materiais, mas também

\footnotetext{
${ }^{22}$ CÉSAR BARROS LEAL, A execução penal... cit., p. 129.

${ }^{23}$ Segundo ALESSANDRA TEIXEIRA: "É nesse sentido, que é possível interpretar a expressão cunhada pela Organização: somos fortes onde o inimigo é fraco. A fraqueza aí descrita é aquela que provém de duas situações que caracterizam de modo peculiar o sistema penitenciário brasileiro: a primeira se manifesta na mais completa ausência do Estado dentro das prisões, sintetizada pelo abandono das responsabilidades referentes à custódia de indivíduos que o poder de punir lhe atribui e das formas escandalosas e corrupção e de "delegação da administração prisional" a partir de acordos e negociações espúrias entre seus representantes e grupos de presos. A segunda manifestação pode ser descrita na falta de força. Em ambos os casos, o que se verifica é o abandono o que confere ao Estado sua vulnerabilidade, tornando-o um inimigo facilmente derrotável.". (Do sujeito... cit., p.133).

${ }^{24}$ CÉSAR BARROS LEAL, A execução penal... cit., p. 125.

${ }^{25}$ GuILHERME DE SOUZA NuCCI, Leis penais ... cit., p.476.
} 
humanos, prestigiando-se o debate acerca dos temas que circundam a execução penal, recuperando o interesse estatal e social sobre esta fase tão delicada do processo penal.

\section{Alternativas}

A triste realidade carcerária do país consente que o condenado se submeta a condições prisionais diversas daquelas estritamente descritas no título judicial condenatório, em clara violação ao princípio da dignidade da pessoa humana.

Insta consignar que as pessoas não foram condenadas a passar privações alimentares, a viver amontoadas, a ser alvo de violência física e sexual, a contrair doenças contagiosas nos estabelecimentos penais. "Toda essa realidade que vigora no mundo dos excluídos significa inconcebível exacerbação da pena.". ${ }^{26}$

Para enfrentar esses problemas e com a finalidade de se evitar o colapso do sistema prisional, algumas alternativas têm sido encontradas pela administração, pelo legislador e pela jurisprudência, que aqui serão citadas apenas para fins de contextualização do sistema carcerário tal como ele se apresenta e de demonstrar a dinâmica que o envolve, não se adentrando profundamente nos assuntos, sob pena de tumultuar e se distanciar do objeto tema da presente dissertação.

Uma mudança importante para combater a superpopulação foi o predomínio do entendimento jurisprudencial pela inconstitucionalidade do artigo $1^{\circ}$ da Lei $n^{\circ} 8.072 / 1990$, que vedava a progressão de regime aos autores de crimes hediondos determinando que a pena fosse cumprida em regime integralmente fechado. Evidente que o cumprimento deste dispositivo legal levou ao colapso o sistema carcerário, inchando as cadeias, tendo as autoridades sido obrigadas a relativizar a ordem legal. Este posicionamento jurisprudencial foi positivado pela Lei $\mathrm{n}^{\circ} 11.464 / 07$ que autoriza aos condenados a crimes hediondos a iniciarem suas reprimendas em regime fechado, reconhecendo-lhes o direito a pleitear a progressão.

Mais do que adequar a lei aos princípios da individualização da pena, a alteração legislativa teve fundamento prático: as prisões estavam ficando superlotadas, principalmente por causa dos condenados por crimes hediondos, já que suas penas teriam que ser cumpridas integralmente em regime fechado.

\footnotetext{
${ }^{26}$ MARCO ANTÔNIO BANDEIRA SCAPINI, Execução penal - Controle da legalidade, Revista CEJ v.5 n.15, dez., 2001, p.54.
} 
Não se pode desconsiderar que geralmente esses crimes são punidos com penas altíssimas, justamente pela natureza hedionda da infração, assim o Estado era obrigado a manter elevado número de presos por longo período, sendo que a construção de novos estabelecimentos prisionais não acompanhava o aumento dos apenados.

A disposição prevista no artigo $1^{\circ}$ da Lei de Crimes Hediondos que perdurou como constitucional por mais de década sempre foi alvo de ferrenhas críticas, pois a manutenção de presos em um único regime desvirtua as finalidades da pena e compromete toda a execução penal levando à dessocialização e à prisionalização.

A prisionalização ${ }^{27}$ é um fenômeno que pode ser definido como a adesão ou capitulação, total ou parcial dos usos e costumes, hábitos e cultura geral da prisão. Os críticos enfatizam que a permanência de presos por longo tempo no regime fechado acabou levando à organização dentro dos presídios, culminando com a criação das temidas facções criminosas, produtos típicos da cultura do cárcere, efeito direto da prisionalização"28

Se a vedação à progressão aos regimes mais leves se revelava um problema, de outro lado, a concessão de progressão, muito embora observados e preenchidos os requisitos legais, também tem representado um impasse para as autoridades judiciárias e uma dificuldade para os órgãos da administração penitenciária.

É corriqueiro que o sentenciado seja promovido ao regime intermediário por decisão judicial, porém, aguarde meses por uma vaga em estabelecimento adequado. Tal fato também agrava a superpopulação, pois os juízes autorizam a progressão, mas esta não é efetivada por problemas atinentes à administração penitenciária.

A insuficiência de vagas inviabiliza o correto desenrolar do processo da execução e contribui para a ruína do sistema progressivo.

O embaraço dessa situação é muito bem condensado nas palavras de Eduardo Pereira Santos ao ponderar que "por isso, o condenado com direito reconhecido definitivamente ao regime semiaberto costuma esperar o dia incerto e longínquo da vaga. Onde espera? No regime fechado. Numa iniquidade chocante. Num disparate. Num absurdo. Num crime. E a lei $?^{29, "}$

\footnotetext{
27 Expressão sinônima é "prisonização", expressão cunhada por Donald Clemmer para resumir a condição a que fica reduzido o sentenciado recolhido a um estabelecimento penal. (MANOEL PEDRO PIMENTEL, Sistemas penitenciários... cit., p.268)

${ }^{28}$ CARMEN SILVIA DE MORAES BARRos, As modificações introduzidas no arts. $6^{\circ}$ e 112 da LEP pela lei 10.792/2003 e a jurisdicionalização e a individualização da pena na execução penal, Revista Brasileira de Ciências Criminais v. 12 n. 48, mai./jun., 2004, p. 185.

${ }^{29}$ Eduardo Pereira Santos, Execução Criminal, Revista Brasileira de Ciências Criminais v.9.n.38, abr./jun. 2002, p.110.
} 
O Poder Judiciário não pode compactuar a incúria do Estado-Administração relacionada à dificuldade em se conseguir vaga em estabelecimento prisional adequado à situação jurídica do sentenciado. Nessa linha, a solução dada pelos tribunais pátrios para a incongruência, consubstanciada na ausência de vaga no regime intermediário que viabilize a efetiva progressão, foi colocar o sentenciado em regime aberto até o surgimento da vaga. Isto porque, o sentenciado não pode ser punido por má administração e omissão estatal.

Outra saída encontrada para aliviar a agonizante realidade do cárcere, é a aposta nas penas alternativas. ${ }^{30}$ Além de não contribuir para o excedente populacional nas cadeias as penas alternativas são as mais indicadas para favorecer a reinserção social do condenado, reduzindo, portanto, a reincidência, na medida em que evitam o contágio do cárcere e não o afastam de seu trabalho e de sua família, bem como são muito menos onerosas que as penas de privação. ${ }^{31}$ Desse modo, as penas alternativas são vistas como as mais aptas para a recuperação do delinquente e mais benéficas para a sociedade como um todo.

Para tentar minimizar o problema da falta de vagas, observa-se uma tendência na construção de megaprisões com maior capacidade de alojamento e com aparato tecnológico visando aumentar a segurança.

A edificação de prisões de segurança máxima consistente em super complexos é encarada com uma solução para o desafio do sistema penitenciário. Acredita-se que o futuro dos estabelecimentos prisionais será observar o binômio segurança e tecnologia.

A implementação do Regime Disciplinar Diferenciado (RDD) também é vista por muitos como um remédio para tentar conter e desarticular a criminalidade organizada que impera dentro e fora dos presídios e tem como cerne o isolamento celular.

De outro lado, o RDD recebe severas críticas. Seus opositores entendem que ele é cruel, fere a dignidade da pessoa humana e não vai ao encontro dos diplomas nacionais e internacionais que orientam a execução da pena, colidindo-se com o ideal ressocializador.

O Regime Disciplinar Diferenciado foi introduzido no ordenamento jurídico pátrio pela Lei $\mathrm{n}^{\circ} 10.792 / 03$, que também alterou a LEP com a proposta pelo fim dos laudos criminológicos como requisito à concessão de benefícios prisionais. ${ }^{32}$ De acordo com a

\footnotetext{
${ }^{30}$ Em oposição, MANOEL PEDRO PIMENTEl comenta que as penas alternativas não contribuem para aliviar a pressão causada pelo excesso de população carcerária, uma vez que a quase totalidade dos sentenciados recolhidos às prisões é composta de condenados ao cumprimento de elevadas penas ou de delinquentes de elevada periculosidade. (Sistemas penitenciários... cit., p.271.)

${ }^{31}$ CÉSAR BARros LeAL, A execução penal... cit., p. 140.

32 Nesse passo, ALESSANDRA TEIXEIRA acena que a proposta pelo fim dos laudos criminológicos para fins de benefícios, na realidade, "representou um passo intermediário na consolidação de um projeto de excelência
} 
referida lei, o preso será inserido no regime diferenciado quando apresentar alto risco para a ordem e a segurança do estabelecimento penal ou da sociedade ou quando recaiam fundadas suspeitas de envolvimento ou participação, a qualquer título, em organizações criminosas ou bando, nos termos do artigo $52, \S \S 1^{\circ}$ e $2^{\circ}$ LEP.

Os que entendem legítima essa medida argumentam que não há a supressão de direitos, pois apenas se disciplinou o exercício de direitos previstos na lei, afinal a estrutura da execução das penas no ordenamento pátrio fundamenta-se no tratamento diferenciado entre os condenados que deverão ser classificados de acordo com suas personalidades, características pessoais e antecedentes, bem como o grau de periculosidade que apresentem.

De outra banda, a positivação do $\mathrm{RDD}$, na visão de muitos, manifesta o assentimento dos Poderes Públicos com práticas arbitrárias, regularmente toleradas no cotidiano das penitenciárias nacionais. ${ }^{33}$

Os opositores do RDD afirmam que ele viola condição de seres humanos dos presos, e equivale à opção por um modelo ultrapassado e bárbaro de punição. O sistema penitenciário nacional depara-se, pois, tragicamente, com uma opção política de eliminação dos seus excluídos que cometeram desvios. ${ }^{34}$

Partindo deste ponto de vista, a alteração legislativa que incorporou o RDD no texto da Lei da Execução Penal legitimou o direito penal máximo e um controle maior por parte do Estado com relação ao presidiário.

A positivação do exame criminológico pela Lei $\mathrm{n}^{0}$ 7.210/84 também pode ser encarada como uma alternativa para aperfeiçoar a execução penal, uma vez que a intenção do legislador era possibilitar que o condenado fosse submetido a um programa individualizado de cumprimento de pena, elaborado de maneira científica, e assim garantir melhores resultados para a reinserção social.

Decerto, essas são apenas algumas das medidas, citadas a título exemplificativo para a compreensão da magnitude do problema vivenciado pela execução penal, que vem sendo aplicadas com o intuito de sustentar e recuperar o sistema penitenciário tal como ele se apresenta.

disciplinar e de desconstrução do sujeito de direitos na prisão, situado entre a instauração do RDD e a meta final que seria alcançada pela desjurisdicionalização da execução penal.” (Do sujeito... cit., p.160)

${ }^{33}$ SAlO DE CARVALHO e CHRISTIANE DE RuSSOMANO FREIRE, O regime disciplinar diferenciado: notas críticas à reforma do sistema punitivo brasileiro, in Crítica à execução penal, $2^{\mathrm{a}}$ ed, Rio de Janeiro:Lumen Iuris, 2007, p.276.

${ }^{34}$ Idem, p. 280. 
Não se pode deixar de reconhecer que a Lei de Execução Penal é um avanço, apresenta bons dispositivos, mas é fato que nunca foi devidamente observada. Evidente que modificações e atualizações podem e devem ser feitas para tornar a Lei de Execução Penal mais efetiva e de acordo com a realidade do seu tempo, não se esquecendo, porém, que a LEP nunca chegou, de fato, a ser aplicada em sua essência o que, caso tivesse acontecido, provavelmente teria evitado que a situação carcerária atingisse o estado caótico atual.

Sintetizando a situação, Nucci prega que antes de defender que a pena de prisão está falida, deve-se voltar os olhos às verdadeiras condições dos cárceres brasileiros, constatando que, na sua imensa maioria, não se cumpre o disposto na Lei de Execução Penal, nem tampouco o Código Penal. Portanto, não se pode ter falido o que nunca teve crédito. $^{35}$

Além das carências materiais e estruturais, a concretização dos comandos legais da Lei de Execução Penal também encontra impedimento no âmbito das mentalidades, pois a cultura prisional dos regimes autoritários vivenciados pelo Brasil (Estado Novo e Ditadura Militar) ainda perdura, fazendo com que diversos segmentos sociais continuem a negar o reconhecimento de direitos aos encarcerados.

Na seara das universidades o ensino sobre a execução penal geralmente é mitigado e "a consequência mais nefasta de tal desatenção acadêmica, é que quando cotejada para aplicação, a Lei de Execução Penal é interpretada observando a filosofia e os princípios que alicerçam o entendimento e aplicação do Código Penal. Ora, tal situação acaba por interferir de modo avassalador no Sistema Penitenciário Brasileiro o qual se tornou refém, também, desta contradição conceitual." ${ }^{\text {36 }}$.

Há pouca doutrina especializada, poucos estudos científicos que ajudem a esquadrinhar um modelo a ser alcançado, promovendo soluções palpáveis e razoáveis para os dilemas do cárcere. As universidades devem contribuir para o aprofundamento do conhecimento nesta área tão delicada que cada vez mais se impõe clamando por alternativas.

Além das alterações na lei e da implementação de políticas públicas, para que se possa conferir um mínimo de racionalidade à execução penal, para que se possa fornecer

\footnotetext{
${ }^{35}$ GUILHERME DE SOUZA NUCCI, Leis penais... cit., p.477.

${ }^{36}$ NoEli KÜHL SvOBODA BessA, Os instrumentos técnicos previstos pela Lei de Execução Penal Brasileira para formalizar a classificação dos condenados e avaliar o requisito subjetivo por ocasião da progressão de regime ou livramento condicional, Direito e Sociedade n.1 v.1, 2000, p.208.
} 
uma resposta adequada às exigências atuais, é preciso capacitar os juízes para essa ingente tarefa, proporcionando-lhes, igualmente, os meios adequados. ${ }^{37}$

A realidade do sistema prisional e da criminalidade contemporânea tem exigido algumas adaptações no entendimento jurisprudencial e na legislação. Assim, como em outros diplomas do ordenamento jurídico pátrio, a execução da pena tem sido alvo de alterações pontuais. Quando se fala de reforma da Lei de Execução Penal, não se pode deixar de reconhecer que esse importante diploma precisa de alguns retoques aqui e acolá. Mas, em seu conjunto, é uma lei muito boa. O que faz falta, fundamentalmente, é uma reforma de postura, uma nova tomada de consciência de todos os operadores do Direito Penal e, especialmente, daqueles que se relacionam com o Direito da Execução Penal ${ }^{38}$.

${ }^{37}$ George LoPes Leite, O papel do juiz na execução penal (mesa redonda IV), Revista CEJ v.5, n.15, dez.2001, p.62.

${ }^{38}$ Idem, p.62. 


\section{CAPÍTULO II - PROCESSO DE EXECUÇÃO PENAL}

\section{Conceito}

O processo é necessário para a apuração do delito, para a imposição ${ }^{39}$ e para a execução da pena. ${ }^{40}$

Execução penal pode ser definida como o conjunto de atos processuais desenvolvidos em observância a uma ordem lógica com o objetivo de atingir a concretização punitiva, regulado pelo direito de execução penal, componente de um capítulo do direito público e que tem constituição jurídica complexa, eis que integrado simultaneamente por normas de direito penal, de direito processual penal e de direito administrativo. $^{41}$

Tem como escopo concretizar o conteúdo do julgado condenatório, ou da sentença que aplicou a medida de segurança, e, é a obrigação imposta pelo poder estatal ao infrator de uma norma penal, fazendo com que o mesmo pague, pecuniariamente ou com sua liberdade, um mal injusto, praticado contra a sociedade. Em se tratando de medida de segurança detentiva, além da prevenção natural, com a retirada do indivíduo do meio social, visa-se seu tratamento médico-psiquiátrico, visto que essa medida será sempre destinada ao indivíduo de imputabilidade no mínimo reduzida. ${ }^{42}$

Imposta a pena, compete ao Estado executá-la. Na expressão de Sidnei Agostinho Beneti “a execução é sempre ação pública, sujeita à regra da obrigatoriedade, pois não seria congruente que o Estado, comprometido, por princípio, com a legalidade e a efetividade de suas leis, deixasse de atribuir a consequência legal ao fato da condenação do acusado, de modo que forçosamente tem ele de executar a sentença penal condenatória.". 43

\footnotetext{
${ }^{39}$ Lembra SiDNEI AGOSTINHO BENETI que "a lei penal, ao contrário da lei material extrapenal, não se aplica independentemente da atividade de jurisdição do Estado, pois impensável a imposição da pena, no Estado de Direito, sem o necessário processo penal, por intermédio de que se opera o controle da exata incidência da norma punitiva, proporcionalizando-se as consequências desta à infração cometida." (Execução penal... cit., p.05).

${ }^{40}$ Em complemento, SIDNEI AGOSTINHO BENETI aduz que "a execução legal, com estrita observância das garantias próprias do Estado de Direito, deve realizar-se por intermédio da atividade jurisdicional, no prosseguimento da intervenção do Estado na órbita dos direitos do condenado" (Execução penal... cit., p.0607)

${ }^{41}$ SÉRgio Mazina MARTins. A construção histórica da execução penal em face da doutrina dos direitos humanos: uma conversação histórica. Dissertação de mestrado. Faculdade de Direito da USP, 2002, p.46.

${ }^{42}$ RUBENS RODRIGUES, A execução penal como instrumento de formulação de políticas preventivas criminais. A Força Policial, n.27, jul./set., 2000, p.5.

${ }^{43}$ SidNei AgostinHo BeneTI, Execução penal...cit., p.86.
} 
A sentença condenatória constitui o título executivo judicial que traça os limites a serem respeitados pelo Estado na pretensão executória da punição.

É na execução criminal que se exerce o jus punitionis em sua plenitude, pois a sentença condenatória é concreta, enquanto título executivo, mas abstrata enquanto não exercida uma vez que somente nos atos de execução é que se materializam seus comandos emergentes. $^{44}$

A ação penal executória inicia-se, em geral, ex officio, com o juiz do conhecimento determinando a expedição da carta de guia ${ }^{45}$ para cumprimento de pena e a remessa desta ao Juízo da execução para instaurar-se o processo de execução. Independente de ser iniciada por iniciativa do juiz, sem a provocação das partes, isto não desvirtua o caráter jurisdicional da execução penal. Evidente que existe uma ação executiva, pois, "mesmo quando independe da iniciativa da parte para a instauração do processo, uma vez instaurado este, a parte fica investida de poderes e faculdades na relação processual, no exercício dos quais estimula o órgão jurisdicional a levar avante o procedimento". 46

O processo de execução penal nada mais é do que instrumento através do qual opera a jurisdição, para a tutela judiciária dos direitos subjetivos do sentenciado e para a efetiva realização do comando concreto emergente da sentença. ${ }^{47}$

Exige-se uma atenção toda especial do juiz da execução que deve estar sempre atento com as alterações legislativas que de alguma forma favoreçam o apenado, podendo retroagir em seu benefício, adequando-se o título executivo a nova realidade. Isto indica que o processo de execução é dinâmico. De tal forma que o título executivo judicial, no que concerne à delimitação do direito de punir, deve ser adaptado a fatos supervenientes. ${ }^{48}$ Assim, o juiz da execução deve ser dotado da especialidade de adaptar o processo da execução da pena à situação de fato ou de direito apresentada, individualizando-a.

\footnotetext{
${ }^{44}$ AleXANDRe Miguel e DANIEL RiBeIRo LAGOS, A execução penal: instrumentalização e competência, Revista dos Tribunais, n 690, abr. 1993, p.400.

${ }^{45}$ Importante deixar claro que a carta de guia, também conhecida como carta de recolhimento, não constitui o título executivo para a execução da pena. Como já exposto no texto, o título executivo é a sentença condenatória ou absolutória imprópria. A carta de guia é simplesmente o documento que certifica a imposição desta sentença, servindo tão somente como fonte informativa.

46 Antonio Carlos de Araújo Cintra, Ada Pellegrini Grinover e CÂndido Rangel Dinamarco, Teoria geral do processo, $21^{\mathrm{a} e d}$., São Paulo:RT, 2004 , p.324.

${ }^{47}$ Ada Pellegrini Grinover, Antonio Magalhães Gomes Filho e Antonio Scarance Fernandes, A exigência de jurisdicionalização da execução. Fascículos de Ciências Penais v.4.n.3, jul./set. 1991, p.4.

${ }^{48}$ WALTER SWENSSON. A competência do juízo da execução, in - Execução penal - visão do TACRIM SP, 1998 , p.218.
} 


\section{Advento da Lei de Execução Penal}

A Lei de Execução Penal surge em um momento de transição de um regime autoritário para um Estado Democrático de Direito. Em 1984, o Brasil ainda estava sob ditatura militar, no entanto, já era possível notar evidências do enfraquecimento do regime e o fortalecimento de movimentos que reivindicavam direitos de diversas ordens, direitos esses geralmente preteridos em regimes de natureza autoritária, bem como a crescente conscientização e a valorização dos direitos humanos.

Importante destacar que no âmbito internacional já existia normatização acerca do tratamento digno a ser dado à pessoa presa, reconhecendo-a como sujeito de direitos, considerando a aprovação em 1955 das Regras Mínimas das Nações Unidas para o Tratamento de Reclusos. Dessa forma, constata-se que o Brasil, com um certo atraso, vivenciava a ideia de que os presos seriam também portadores de direitos humanos, e debatia como seria possível uma política penal que ao mesmo tempo prevenisse crimes e reprimisse com a perspectiva de sua ressocialização."49.

De acordo com Alessandra Teixeira, "as mobilizações para a libertação dos presos políticos e sua anistia, uma das mais importantes bandeiras pelo fim do regime militar, foram os primeiros movimentos a lançar luz sobre a realidade das prisões, ainda que priorizando um público que lá se encontrava circunstancialmente encarcerado."50.

Coerente se mostra o apontamento, pois, em geral, o público encarcerado compõese de segmentos sociais menos privilegiados e sem força política, portanto, não era incomum serem esquecidos, não se importando a sociedade com o que lhes acontecia. A coletividade queria ver os transgressores punidos, condenados, mas não se importava em que condições essa punição era cumprida.

Com a prisão de presos políticos, geralmente intelectuais, militantes, pessoas mais engajadas em movimentos político-sociais, a atuação coercitiva do Estado estendeu-se a outro setor da população. Nesse contexto, é natural que a questão penitenciária tenha virado alvo de atenção, pois, naquele momento, essas pessoas com maior destaque na sociedade vivenciaram, em sua maioria, pessoalmente a realidade carcerária. O que antes era desconhecido ou considerado não merecedor de interesse passou a ser revelado e digno de discussão.

\footnotetext{
${ }^{49}$ AlesSANDRA TEIXEIRA. Do sujeito... cit., p.51.

${ }^{50}$ Idem, p.49.
} 
Desse modo, no início da década de 80, verifica-se mobilização da sociedade civil para denunciar "a realidade enfrentada e das violações dos direitos sofridas pelos presos comuns, introduzindo ainda o debate da seletividade do controle penal e do estigma recaído sobre a população pobre das periferias urbanas, cliente preferencial da atuação policial, como centrais na compreensão do arbítrio e da violência promovidos pelo sistema criminal.", 51

Sob essa conjuntura, em 1984, foi promulgada a primeira Lei de Execução Penal do Brasil, acompanhada também da reforma do Código Penal.

Antes da promulgação de lei específica sobre a matéria, a execução penal era regulamentada por estatutos administrativos disciplinares, e, posteriormente, no Livro IV do Código de Processo Penal, que embora não tenha sido expressamente revogado pela Lei $\mathrm{n}^{\circ} 7.210 / 1984$, é fato que a matéria foi totalmente regulamentada pelo novo diploma legal.

Normas sobre execução da pena encontram-se espalhadas pelo Código Penal (reformado em 1984), pelo Código de Processo Penal e pela Constituição Federal de 1988, o que demonstra a complexidade da matéria, o que por algum tempo rendeu a ideia de submissão da execução penal aos domínios do Direito Penal, ou do Direito Processual Penal ou Direito Administrativo.

Com a edição da Lei $n^{\circ} 7.210 / 1984$, firmou-se o entendimento pela autonomia da execução penal. Encontra-se na própria Exposição de Motivos da Lei de Execução Penal, item 12, o seguinte esclarecimento: a execução das penas e das medidas de segurança deixa de ser um Livro do Código de Processo para ingressar nos costumes jurídicos do país com a autonomia inerente à dignidade de um novo ramo jurídico: o Direito de Execução Penal.

A promulgação da Lei de Execução Penal também foi essencial para consagrar o princípio da jurisdicionalização da execução penal, reconhecendo o preso como sujeito de direitos, e os princípios da individualização e da progressividade da pena atribuindo à pena a finalidade de ressocialização.

\footnotetext{
${ }^{51}$ Ibidem, p.50.
} 


\subsection{Autonomia do processo de execução}

Por certo tempo, definir se a execução da pena caracterizava uma nova ação e um novo processo ou se apenas se tratava do prosseguimento da ação penal e de nova fase do processo penal de conhecimento, revelou-se tema tormentoso.

Inicialmente, perdurou a ideia de que o processo de execução da pena seria mero prolongamento do processo de conhecimento. Nessa esteira, a execução penal era vista tão somente como uma fase do processo penal de conhecimento. No entanto, essa visão demonstrou-se equivocada, passando a prevalecer o entendimento de que o processo de execução penal é novo processo, que se constitui para a efetivação do título executório. ${ }^{52}$

A fim de demonstrar as diferenças existentes entre o processo penal de conhecimento e o processo de execução penal para consolidar o entendimento pela autonomia do processo de execução da pena, Sérgio Marcos de Moraes Pitombo aponta que "o processo penal de conhecimento volta-se para o passado, que tende a reconstruir. $\mathrm{O}$ processo penal de execução mira o futuro e visa a prevenir infrações penais, de modo prevalente, sem esquecer do castigo medido." 53 .

A autonomia do processo de execução penal é facilmente detectada, uma vez que se forma nova relação jurídica, distinta daquela do processo de conhecimento, pois, apesar de identidade de sujeitos processuais - Juiz, Ministério Público e réu, ora condenado - os três agem com objetivos inteiramente diversos. O Ministério Público agora quer o cumprimento da pena; antes pretendia a condenação. O juiz da execução não mais instrui a causa para julgar a ação penal; deve velar para que o cumprimento da pena seja feito nos termos da lei e deve buscar a maior individualização possível, adaptando o comando emergente da sentença aos novos interesses da execução. $O$ condenado não mais pugna pela sua absolvição; quer amenizar a forma de cumprimento da pena, quer que sejam observados os seus direitos, pretende que lhe sejam outorgados os benefícios legais. $\mathrm{O}$ objeto do processo de execução é outro, não mais a pretensão deduzida pela acusação e sim o cumprimento do comando emergente da sentença condenatória e sua adaptação de acordo com as necessidades da execução em concreto. ${ }^{54}$

\footnotetext{
52 Sidnei AgOSTinho Beneti, Execução penal... cit., p.48.

${ }^{53}$ SÉrgio Marcos de Moraes Pitombo, Execução Penal, Revista de Política Criminal e Penitenciária v.1.n.1, jan/jun 1998, p. 220.

${ }^{54}$ ANTONIO SCARANCE FERNANDES, Execução penal: aspectos jurídicos, Revista CEJ v.3.n.7, abr.1999, p.69.
} 
A autonomia do processo de execução penal decorre da ideia do exercício de uma jurisdição altamente especializada, nos termos do item 15 da Exposição de Motivos da Lei de Execução Penal.

Trata-se de ciência autônoma, com princípios próprios, embora sem, jamais, desvincular-se do Direito Penal e do Direito Processual Penal, pois o primeiro regula vários institutos de individualização da pena, úteis e utilizados pela execução penal, enquanto o segundo estabelece os princípios e as formas fundamentais de se regular o procedimento da execução, impondo garantias processuais penais típicas, como o contraditório, a ampla defesa, o duplo grau de jurisdição, entre outras. ${ }^{55}$

A obrigatoriedade de um processo penal executório (ou processo de execução penal) corresponde às exigências de autonomia científica do Direito de Execução Penal e se traduzirá nos movimentos de expansão e eficácia da jurisdição em zona juridicamente neutra - como se chamou o território de execução - principalmente quando se puder contar com uma magistratura especializada para se desincumbir da missão fundamental do Direito Penal: tornar efetivos os seus comandos de reação ao delito. ${ }^{56}$

Superada a ideia de que o processo de execução seria continuação do processo de conhecimento, se consolida a autonomia da execução penal, uma jurisdição especializada distinta daquela do Juízo criminal, dotada de uma lei própria, a Lei de Execução Penal, e com regras estabelecidas segundo um ramo do Direito autônomo, o Direito de Execução Penal ou Direito Penitenciário. ${ }^{57}$

Guilherme de Souza Nucci discorda do tratamento sinonímico entre as denominações Direito de Execução Penal e Direito Penitenciário, e explica: "a insuficiência da denominação Direito Penitenciário torna-se nítida, na medida em que a Lei de Execução Penal cuida de temas muito mais abrangentes do que a simples execução de penas privativas de liberdade em presídios.". 58

Mesmo posicionamento é manifestado por Mirabete ao pontuar que a execução penal além de buscar o efetivo cumprimento das penas e medidas de segurança privativas de liberdade, também envolve as medidas assistenciais, curativas e de reabilitação do condenado, "o que leva à conclusão de ter-se adotado em nosso direito positivo o critério da autonomia de um Direito de Execução Penal em vez do restrito Direito

\footnotetext{
${ }^{55}$ Gullherme de SouZa NuCCI, Manual de Processo Penal e Execução Penal, $3^{\mathrm{a}}$ ed., São Paulo:RT, 2007, p.942.

${ }^{56}$ RENÉ ARIEL DotTI. A lei de execução... cit.,p. 206.

${ }^{57}$ WALTER SWENSSON. A competência... cit., p.219.

${ }^{58}$ GuILHERME DE SOUZA NuCCI, Leis penais ... cit., p.401.
} 
Penitenciário.". ${ }^{59}$ O que permite a conclusão de que a nomenclatura de Direito de Execução Penal é mais abrangente e encampa o Direito Penitenciário.

Um desdobramento prático da autonomia do processo executório é o processamento da execução da pena em autos apartados, relevante para instrumentalizar o novo processo que se inicia, desvinculado do processo de conhecimento, embora guarde estreita correlação com este.

A formação dos autos de execução em apartado favorece a individualização da pena. Enquanto no processo de conhecimento podem figurar vários réus, na execução da pena, são formados autos para cada condenado como medida adequada para a verificação individual condições subjetivas dos apenados diante de cada fase do processo, podendo ensejar situações diferentes de evolução ou regressão. ${ }^{60}$

Efetuar o processo de execução em autos de execução apartados também se justifica para as hipóteses de alteração do local de cumprimento da pena. Nos casos de transferência do local de execução, automaticamente é transferida a competência para o novo juízo. ${ }^{61}$

\subsection{Jurisdicionalização da Execução}

A principal contribuição da Lei de Execução Penal de 1984 foi dirimir, no Brasil, de uma vez por todas as dúvidas acerca da natureza jurídica da atividade judicial exercida na execução penal, consolidando-a como jurisdicional.

O debate sobre natureza jurídica da execução penal é de extrema relevância, pois mais do que envolver a previsão da figura do juiz da execução, a ideia de jurisdicionalização abrange a discussão acerca do status jurídico do preso, ou seja, se ele é simples detentor de deveres e obrigações ou sujeito de direitos que não foram atingidos pela condenação.

Em síntese, acerca da natureza jurídica da execução penal as principais correntes sobre a questão são: a que define a natureza jurídica como sendo administrativa; a posição intermediária que entende que a execução penal seria preponderantemente administrativa, mas com jurisdicionalidade episódica, nos chamados incidentes de execução; e, por fim, a que prega a atividade jurisdicionalizada da execução da pena.

\footnotetext{
${ }^{59}$ Julio FABBrini MiRABETE, Execução Penal... cit., p. 23.

${ }^{60}$ AleXANDRE Miguel e DANIEL RIBEIRo LAGOS, A execução penal... cit., p.400.

${ }^{61}$ Idem, p.400.
} 


\subsubsection{Sistema administrativo.}

Segundo este posicionamento a execução da pena é procedimento administrativo a cargo da administração penitenciária, a ser gerido apenas pelo Poder Executivo, e a atuação do juiz seria de caráter meramente fiscalizatório.

Sob essa ótica, o juiz apenas exerce atividade de vigilância, consistente em mera fiscalização de correto cumprimento da sentença condenatória, de controle sobre os atos da autoridade administrativa, ou toma medidas tendentes a permitir a ressocialização do condenado, mas não decide, não resolve questões.

De acordo com René Ariel Dotti, “a compreensão de que a execução penal tem natureza puramente ou prevalentemente administrativa radica na concepção política e jurídica em harmonia com a distinção entre momentos da cominação, da aplicação e da execução como correspondentes aos Poderes do Estado, segundo a clássica tripartição de Montesquieu.". ${ }^{2}$ Explica que "a teoria de Montesquieu seria a base fundante do critério da divisão da pena em etapas. Ao Poder Legislativo caberia a elaboração das normas; ao Judiciário, a sua aplicação, e ao Executivo, a observância do cumprimento.". 63

Para essa corrente a função jurisdicional se esgotaria com a prolação da sentença, conferindo-se à execução penal um caráter eminentemente administrativo.

Sidnei Beneti assinala que "nota característica do sistema administrativo é a falta de ênfase legislativa especial nas garantias de execução penal e, também, inexistência de Juízo especial de execução da pena, ou redução deste à atividade administrativa, o que coloca o condenado sob o regramento de normatividade secundária como Decretos e Regulamentos, e sob a decisão puramente do administrador do presídio, agindo este, verdadeiramente, como 'supercarcereiro'., 64.

O sistema administrativo é adotado pela França (com tendência a mitigação), Inglaterra, Estados Unidos, onde se aplica a doutrina do Hands-off, ou seja, a jurisdição se conserva alheia ao destino dos condenados, e pela quase a totalidade dos países da América Latina. ${ }^{65}$

\footnotetext{
${ }^{62}$ RENÊ ARIEL DotTI, A lei de execução ... cit., p. 202.

${ }^{63}$ Idem, p. 202-203.

${ }^{64}$ SiDNEI AGOSTINHO BENETI, Execução penal...cit., p.17.

${ }^{65}$ Idem, p.17-18.
} 


\subsubsection{Sistema misto}

A posição intermediária defende a existência de conciliação de atos de administração com atos de jurisdição na execução penal. Desse modo, competiria ao juiz da execução o papel administrativo na fiscalização e no acompanhamento dos trabalhos desenvolvidos nas penitenciárias, contudo, nos incidentes exerceria função jurisdicional.

Consoante este entendimento, a execução seria preponderantemente administrativa, mas com jurisdicionalidade episódica nos chamados incidentes de execução.

No Brasil, como manifestação desse modelo pode-se citar a regulamentação do livramento condicional, em 1924, cuja concessão passava a depender de uma decisão judicial.

Entre a promulgação do Código de Processo Penal em 1941 e a Lei de Execução Penal de 1984, foi possível observar a vigência desse modelo misto. Nesse sentido, René Ariel Dotti assinala que "no sistema do Código de Processo Penal brasileiro, a execução tem caráter misto: é jurisdicional e administrativa (arts. 668 e ss.). A resolução dos chamados "incidentes de execução"; o controle sobre a internação em manicômio judiciário (ou outro estabelecimento) do sentenciado a que sobrevier doença mental; a deliberação; sobre a forma de pagamento da multa; a comunicação à autoridade competente sobre a imposição de pena acessória; o deferimento da reabilitação; a imposição de medida de segurança superveniente e a fixação de normas de conduta a serem observadas durante a liberdade vigiada constituem matérias da competência jurisdicional.". 66

\subsubsection{Sistema jurisdicional}

Por derradeiro, existe a corrente que prega a jurisdicionalização da execução penal, que é a que prevalece no Brasil após a vigência da Lei nº 7.210/84.

A Lei $n^{\circ} 7.210$ de 1984 unificou as normas sobre execução penal, tanto no plano administrativo como jurisdicional, sob o mesmo diploma legal e instituiu a jurisdicionalização do procedimento executório, que por muito tempo foi considerado puramente administrativo, apontando o caráter complexo da execução.

${ }^{66}$ RenÉ ARIEl DotTI, Processo penal executório, Revista dos Tribunais n. 576, out.1983, p.313. 
De fato, a execução penal é atividade complexa, que se desenvolve, entrosadamente, nos planos jurisdicional e administrativo. Dessa atividade participam dois poderes estatais: o Judiciário e o Executivo, por intermédio, respectivamente, dos órgãos jurisdicionais e dos estabelecimentos penais. ${ }^{67}$

A execução da pena é jurisdicionalizada, inobstante também apresente carga administrativa em caráter colaborativo. A atividade conjunta entre a Administração e o Judiciário é importante para enfrentar os problemas da execução, logo, o controle jurisdicional não deve ser visto como absoluto, uma vez que há a divisão de algumas incumbências entre o juiz da execução e o diretor do estabelecimento. ${ }^{68}$

Ao exercer a vigilância sobre os órgãos administrativos e particulares incumbidos de efetuarem o cumprimento da pena, o juiz também está exercendo atividade jurisdicional na medida em que está contribuindo para a efetivação do comando condenatório tal qual lançado na sentença, e proporcionando condições para a reinserção social do cativo.

Reconhecer o entrosamento entre o Poder Judiciário como o Poder Executivo não significa que a execução penal adote um sistema misto, sendo necessário fazer a seguinte distinção: "a aplicação da pena é objeto do direito penitenciário, o qual se liga ontologicamente ao direito administrativo, muito embora suas regras possam encontrar-se nos códigos penal e processual penal. Mas a tutela tendente à efetivação da sanção penal é objeto do processo de execução, o qual guarda natureza indiscutivelmente jurisdicional e faz parte do direito processual.". ${ }^{69}$

Dizer que a execução penal no Brasil é jurisdicionalizada significa dizer que para qualquer alteração na situação dos apenados, faz-se mister a existência de um processo de execução, com as garantias da ampla defesa, do contraditório e as demais inerentes ao direito material e ao instrumental. Logo, sob o ângulo processual, a execução consiste em modalidade de tutela jurisdicional, correspondente à atuação de órgão do Poder Judiciário, aplicando norma jurídica especificada à satisfação do poder-dever estatal de punir ou sancionar reconhecido em sentença condenatória penal. ${ }^{70}$

\footnotetext{
${ }^{67}$ Ada Pellegrini Grinover, Antonio Magalhães Gomes Filho, Antonio Scarance Fernandes. $A$ exigência..., cit., p.4.

${ }^{68}$ RENE ARIEL DOTTI, Execução penal no Brasil: aspectos constitucionais e legais. Revista dos Tribunais n.664, fev.1991, p.244.

${ }^{69}$ Ada Pellegrini Grinover, Natureza Jurídica da execução penal, in Execução Penal, São Paulo: Max Limonad, 1987, p.07.

${ }^{70}$ Sérgio Marcos de Moraes Pitombo, Execução Penal. Revista de Política Criminal e Penitenciária. Brasília.v.1.n.1jan/jun. 1988, p. 218.
} 
A execução deixa de ser vista somente como a fase de exaurimento do título condenatório, na qual o Estado executa o ius punitionis, mas passa a ser encarada como um momento em que o Estado também deve dar tutela jurisdicional aos cativos, que são titulares de direitos públicos subjetivos.

A Constituição Federal de 1988 só veio reforçar e consagrar esse entendimento. A partir da promulgação da Constituição Federal de 1988, não há mais dúvidas acerca do caráter jurisdicional da execução da pena, tampouco há que se defender o caráter misto da execução, pois com a instauração da nova ordem constitucional o apenado passa a ser detentor de garantias individuais e de direitos fundamentais.

O principal argumento para o reconhecimento da natureza jurisdicional da execução penal, harmonizando-a com a nova ordem jurídica estabelecida pela Constituição de 1988, é que a natureza administrativa que se quisesse emprestar à execução penal tornaria o réu mero objeto do procedimento, quando, ao contrário, ele há de ser visto como titular de situações processuais de vantagem, como sujeito da relação processual existente no processo de execução penal. Não mais simples detentor de obrigações, deveres e ônus, o réu tornar-se titular de direitos, faculdades e poderes. ${ }^{71}$

$\mathrm{Na}$ expressão de Sidnei Agostinho Beneti, “o reconhecimento da existência de direitos fundamentais do condenado tornar-se mais saliente no tocante à pena privativa de liberdade, à vista da especial relevância desse direito restringido pela pena. Mas, a rigor, não há, modernamente, razão lógica para excluir a garantia de direitos fundamentais do condenado, relativamente aos condenados a penas de outras modalidades, bem como a medidas de segurança. Todas as penas, em verdade, caracterizam a supressão, com a chancela penal, ainda que transitória, de direitos do condenado, pelo Estado, que não se pode permitir a infringência de nenhum dos direitos e garantias individuais de ninguém, mormente por intermédio da sanção penal. Todos os atingidos pelas consequências da aplicação da lei penal suportam a incidência de medidas indesejadas, que lhes suprimem direitos cujo exercício lhes decorreria do direito comando da voluntariedade pessoal, de modo que nenhum dos direitos restringidos pode ser alcançado, em execução, em extensão maior do que o da imposição do Estado, realizada por intermédio da sentença penal." ${ }^{, 72}$.

A jurisdicionalização da execução penal sustenta-se no entendimento de que não apenas no processo penal, mas em toda a atividade de execução da pena individualizada na

\footnotetext{
${ }^{71}$ Ada Pellegrini Grinover, Antonio Magalhães Gomes Filho, Antonio Scarance Fernandes, A exigência ... cit., p.6

${ }^{72}$ Sidnei AgostinHo BeneTI, Execução penal... cit., p.10-11.
} 
sentença, há sempre um conflito de interesses que, além do mais aparente conflito entre dois sujeitos - o Estado de um lado e o cidadão titular do direito individual específico do outro - é, acima disto, um conflito que se esboça dentro do próprio Estado. Se por um lado o Estado tem todo o interesse em impor uma sanção e executá-la, por outro não deixa de ter interesse na preservação do jus libertatis do cidadão, relacionado a diversos direitos fundamentais garantidos pela Constituição da República. ${ }^{73}$

Conforme se extrai da obra de Mirabete, a justiça penal não termina com o trânsito em julgado da sentença condenatória, mas realiza-se, principalmente, na execução. É o poder de decidir o conflito entre o direito público subjetivo de punir (pretensão punitiva ou executória) e os direitos subjetivos concernentes à liberdade do cidadão ${ }^{74}$.

Com a jurisdicionalização no cumprimento da pena a relação do preso com o Estado Punitivo altera-se e passa a ser encarada como litígio, na medida em que o preso pode demandar pelo exercício de seus direitos por meio do devido processo legal.

O procedimento da execução possui natureza judicial, no qual autoridade competente para ditar o Direito é o juiz da execução, admite-se a produção de prova, todas as decisões são recorríveis, e se assegura a observância de garantias constitucionais como o devido processo legal, a igualdade, a ampla defesa, o contraditório, o duplo grau de jurisdição e publicidade. ${ }^{75}$

Nas palavras de Antonio Scarance Fernandes, evidenciar que a execução penal é jurisdicional representa, antes de tudo, admitir a existência de um processo de execução cercado das garantias constitucionais, marcado pela presença de três sujeitos principais dotados de poderes, deveres, direitos, obrigações e, por conseguinte, implica aceitar que o condenado é titular de direitos. Mais importante, portanto, do que a própria afirmação da jurisdicionalidade da execução é a verificação dos primordiais reflexos decorrentes do fato de ser ela atividade jurisdicionalizada: garantia de um devido processo legal, no qual se assegura o contraditório entre as partes e a imparcialidade do órgão judiciário. ${ }^{76}$

Em suma, "o reconhecimento da existência de uma relação jurídico processual na execução penal fortalece a posição do apenado, assegurando-lhe a eficácia de seus direitos

\footnotetext{
${ }^{73}$ DyrCeu Aguiar Dia CinTRA Junior, A jurisdicionalização do processo de execução penal, Revista Brasileira de Ciências Criminais .v.3. n.9, jan/mar 1995, p 119.

${ }^{74}$ Julio FABbrini MiRABete, Execução Penal... cit.,p. 32.

${ }^{75}$ Nesse sentido, a Súmula $n^{\circ} 85$ das mesas de Processo Penal da Faculdade de Direito de São Paulo "São garantias plenamente aplicáveis ao processo de execução penal, como decorrência dos princípios constitucionais do devido processo legal, ainda que a lei processual não as assegure expressamente, a igualdade, a ampla defesa, o contraditório, o duplo grau de jurisdição, a publicidade.”.

76 ANTONIO SCARANCE FERNANDES, Reflexos relevantes de um processo de execução penal jurisdicionalizado, Revista Brasileira de Ciências Criminais v. 1, n.3,jul./set. 1993, p.84.
} 
e garantias fundamentais não atingidos pela sentença. Com isso, o apenado deixa de ser um mero objeto e passa a ter o status de parte integrante do processo e, como tal, possuidor de um conjunto de direitos subjetivos exigíveis do Estado." 77 Consagrado o apenado como parte no processo de execução penal, consequentemente, os princípios constitucionais ligados ao devido processo legal, como o contraditório, consubstanciado no direito de informação e participação das decisões judiciais que lhe afetem de alguma forma, também passam a lhe ser assegurados.

Evidente que a previsão da jurisdicionalização da execução penal além de orientar mudanças no plano jurídico-teórico, também traz implicações no plano prático, uma vez que para sua operacionalização e efetivação, exige-se "um empenho conjunto entre os Poderes Executivo e Judiciário com vistas ao aparelhamento do sistema de justiça de execução - criação de varas de execução criminal, defensorias públicas, dotação de pessoal técnico e administrativo, além da própria reformulação da administração penitenciária. Para além, desse empreendimento físico e operacional, a efetividade do princípio jurisdicionalizador exigiria ainda uma predisposição do juiz de execução, como principal ator designado pela legislação, a assumir a centralidade de tal processo.". 78

O juiz passa a encampar a importante função de garantidor, devendo tutelar os direitos subjetivos do encarcerado ora reconhecidos com a jurisdicionalização da execução penal. E é notório que os problemas carcerários do atual cenário exigem uma maior atuação do juiz no âmbito da execução da pena, sendo necessária a criação de novas alternativas para o cumprimento adequado da reprimenda.

Consolidado o entendimento de que "o processo de execução penal é processo de partes, que assegura ao sentenciado as garantias do 'devido processo legal', decorrentes diretamente da Constituição, mesmo no silêncio dos Códigos", ${ }^{79}$ o processo de execução penal deverá ser adequado e interpretado de acordo com os ditames constitucionais, distinguindo-se as funções das partes para equilibrar a relação estabelecida entre juiz, promotor e apenado, por seu defensor.

\footnotetext{
${ }^{77}$ AUry LOPES JR., Revisitando o Processo de Execução Penal a partir da Instrumentalidade Garantista, in Crítica à execução penal, Rio de Janeiro: Lumen Juris, 2007 p. 379.

${ }^{78}$ Aless ANDRA TEIXEIRA, Do sujeito... cit., p.70.

${ }^{79}$ Súmula 44 das Mesas de Processo Penal da Faculdade de Direito da USP.
} 


\section{O Ministério Público}

Muito se discute acerca da natureza jurídica da função processual do Ministério Público, e, na execução penal não poderia ser diferente.

A posição do Ministério Público no processo de execução penal é controversa. Alguns defendem que ele atue somente nessa fase como custos legis, outros já entendem que ele é parte. ${ }^{80}$

Analisando a questão da natureza jurídica das funções exercidas pelo Ministério Público no processo de maneira geral, Antonio Scarance Fernandes concluiu que "o Ministério Público age, às vezes, como sujeito do contraditório, e, outras vezes, como sujeito processual não participante do contraditório. Mas sempre como parte.”. 81

No âmbito penal, o Ministério Público zela para que os criminosos sejam punidos. $\mathrm{Na}$ execução penal o Ministério Público exerce uma função diferente daquela que exercia no processo de conhecimento: antes pretendia a condenação e agora quer o efetivo e correto cumprimento da pena. Não se pode esquecer que na execução penal, além de defender a realização efetiva do comando emergente da sentença criminal, o Ministério Público também deve atuar para que o sentenciado atinja sua reintegração social.

Antes da edição da Lei $n^{\circ}$ 7.210/84, a intervenção do Ministério Público era facultativa e acanhada. Porém, com o advento da atual Lei de Execução Penal e fixada a ideia de ser a execução penal jurisdicional, o Ministério Público recebeu novo tratamento e sua atuação foi prestigiada, reconhecendo-se sua importância para o bom desenvolvimento do processo executório.

Resta clara a intenção da novel legislação em garantir desde o início do processo de execução a participação do Ministério Público, basta considerar que deverá ser dada ciência da expedição de guia de recolhimento (artigo 106, LEP) e de internamento (artigo 173, LEP) ao Paquet. A presença do Ministério Público também é resguardada durante o processo de execução, cabendo ao órgão se pronunciar nos procedimentos judiciais, nos termos do artigo 196, da LEP.

Sobre o assunto, como bem anotado por René Ariel Dotti, "um simples confronto entre as disposições da Lei de Execução Penal e os textos que, na vigência do Livro IV do Código de Processo Penal, regulavam a execução das penas e medidas de segurança, serve

\footnotetext{
${ }^{80}$ Sidnei Agostinho Beneti, Execução penal... cit., p.75.

${ }^{81}$ ANTONIO SCARANCE FERNANDES, O ministério público na execução penal, in Execução Penal, São Paulo: Max Limonad, 1987, p.28.
} 
de ilustração para demonstrar que o procedimento de execução sob novo diploma não admite a ausência do Ministério Público.”. ${ }^{82}$ E complementa "a tímida e geralmente facultativa interveniência do Ministério Público no procedimento de execução conforme o diploma derrogado contrasta, radicalmente, com as previsões da Lei de Execução Penal a começar com a ciência obrigatória da expedição da carta guia.". 83

A Lei de Execução Penal dispõe em seu artigo 67 que o Ministério Público fiscalizará a execução da pena e da medida de segurança, oficiando no processo e nos incidentes de execução.

O artigo 68, da LEP $^{84}$ elenca as atribuições específicas do Ministério Público na esfera da execução penal. Trata-se de um rol exemplificativo e não exaustivo. Tomando por partida o disposto no artigo 68, da LEP, tem-se que o Ministério Público pode funcionar tanto como sujeito processual (inciso II e III) como entidade de fiscalização (inciso I). Desse modo, sua atuação se daria nas duas perspectivas ${ }^{85}$, considerando que ser fiscal da lei não significa não ser parte e vice-versa.

O paragrafo único do artigo 68, da LEP, estipula a visita mensal aos estabelecimentos penais com a finalidade de "possibilitar ao Ministério Público a fiscalização das atividades administrativas ligadas à execução penal, ou seja, de verificar se a lei de ordem pública está sendo cumprida em toda a sua extensão, possibilitando-se lhe as

\footnotetext{
${ }^{82}$ RenÉ ARIEl DotTI, A crise da execução penal e o papel do Ministério Público, Justitia 47(129), abr./jun. 1985, p.51.

${ }^{83}$ Idem, p.51.

${ }^{84}$ Art. 68. Incumbe, ainda, ao Ministério Público:

I - fiscalizar a regularidade formal das guias de recolhimento e de internamento;

II - requerer:

a) todas as providências necessárias ao desenvolvimento do processo executivo;

b) a instauração dos incidentes de excesso ou desvio de execução;

c) a aplicação de medida de segurança, bem como a substituição da pena por medida de segurança;

d) a revogação da medida de segurança;

e) a conversão de penas, a progressão ou regressão nos regimes e a revogação da suspensão condicional da pena e do livramento condicional;

f) a internação, a desinternação e o restabelecimento da situação anterior.

III - interpor recursos de decisões proferidas pela autoridade judiciária, durante a execução.

Parágrafo único. O órgão do Ministério Público visitará mensalmente os estabelecimentos penais, registrando a sua presença em livro próprio

${ }^{85}$ Enquanto no processo penal de conhecimento o Ministério Público situa-se em posição oposta ao réu, no processo de execução da pena, "atua de forma bifronte: representando a sociedade a quem tanto interessa a punição dos infratores da lei penal e o controle dos inimputáveis e semi-imputáveis, quanto à não-infração das leis e administrativas por parte dos encarregados da efetivação das sanções penais e medidas de segurança, o Ministério Público é incumbido de pleitear medidas judiciais (art. 68, II e III) ou tomar providências administrativas, previstas, ambas as incumbências, no art.68, I, e parágrafo único, da Lei de Execução Penal. (SiDnei Agostinho BENETI, Execução penal... cit., p.75.)
} 
medidas judiciais e administrativas para sanar as ilegalidades constatadas durante as visitas." 86

Conclui-se que "o Ministério Público deve participar de todo o processo executivo, podendo requerer qualquer diligência necessária para a efetivação dos interesses que persegue" ${ }^{\text {87 }}$, os quais, na execução, consistem tornar efetiva a pretensão punitiva do Estado e em buscar a reintegração social do sentenciado. A participação do Ministério Público é necessária para tornar o contraditório efetivo, garantindo-se assim a imparcialidade do juiz.

\section{O sentenciado e seu defensor.}

Reconhecer a natureza jurisdicional da execução penal confere ao condenado a condição de titular de direitos, faculdades e poderes em relação ao Estado. Assim, ficam asseguradas ao condenado as garantias constitucionais do devido processo legal, abrangendo o direito de defesa, aqui compreendido como autodefesa e defesa técnica.

Ainda que a defesa não venha indicada expressamente na Lei de Execução Penal, sua atuação no processo é exigência que decorre da Constituição. Ademais, "não seria razoável garantir a assistência do defensor técnico durante a fase de conhecimento e suprimi-la justamente na oportunidade em que são possíveis as modificações na sanção e no modo de seu cumprimento.". 88

Assim, a defesa é órgão que atua no processo de execução ${ }^{89}$ ao qual são aplicáveis todas as garantias processuais decorrentes do devido processo legal tais quais o contraditório, o duplo grau de jurisdição, a publicidade, a "par condicio", etc..

Importante pontuar que "a defesa do condenado no processo de execução penal não se confunde, pois, simplesmente, com a eventual oposição às pretensões dos órgãos estatais incumbidos de promover o cumprimento das penas impostas, mas se caracteriza, antes de tudo, como um conjunto de garantias através das quais o sentenciado tem a possibilidade de influir positivamente no convencimento do juiz da execução, sempre que

\footnotetext{
${ }^{86}$ JUlio FABbrini MiRABete, Execução Penal... cit.,p. 232.

87 ANTONIO SCARANCE FERNANDES, O ministério público na execução penal, in Execução Penal, São Paulo: Max Limonad, 1987, p.32.

${ }^{88}$ Antonio Magalhaes Gomes FiLho, A defesa do condenado na execução penal, in Execução Penal, São Paulo: Max Limonad, 1987, p.42.

${ }^{89}$ AdA PELLEGRINI GRINOVER, Anotações sobre os aspectos processuais da Lei de Execução Penal, in Execução Penal, São Paulo: Max Limonad, 1987, p.16.
} 
se apresente uma oportunidade de alteração da quantidade ou da forma da sanção punitiva." 90

Diferente do que ocorre no processo de conhecimento, o condenado não mais pugna pela sua absolvição, mas sim quer amenizar a forma de cumprimento da pena, quer que sejam observados os seus direitos que não foram atingidos pela condenação, e pretende que lhe sejam outorgados os benefícios legais.

O ambiente carcerário é um ambiente tenso por natureza, afinal, o comum é que as pessoas se sintam inconformadas com a condenação, insatisfeitas com a privação da liberdade, e, talvez, até injustiçadas. Desse modo, "é importante que o preso sinta ao seu alcance a possibilidade de lançar mão das medidas judiciais capazes de corrigir eventual excesso de pena, ou que possa abreviar os dias de prisão" "91, por isso é fundamental garantir a defesa técnica ao sentenciado.

A atuação da defesa técnica na execução penal colabora com a adequada execução da pena imposta. São muitas as possibilidades de atuação do defensor na execução penal que pode, por exemplo, "requerer a aplicação de lei nova mais benéfica nas hipóteses dos crimes praticados anteriormente à vigência da reforma penal. Pode ainda requerer o livramento condicional ou a transferência para o regime menos severo e ajudar na fundamentação de reivindicações, tais como pedidos de transferência, visitas, autorizações de saída, indulto, remição e outros benefícios regulamentares previstos na lei e nos regulamentos, bem como na defesa quando do procedimento para apuração da falta disciplinar etc..." 92

A participação no processo de execução penal do condenado, que é o principal interessado e afetado pelas decisões judiciais tomada no bojo dos autos, se dá por intermédio da defesa técnica. Ademais, é através da atuação de um defensor tecnicamente habilitado que se garante a paridade, possibilitando nivelar a desigualdade entre o condenado, geralmente leigo em conhecimentos jurídicos, perante o órgão ministerial, cujos membros possuem notório saber em direito.

As modificações da sentença condenatória penal transitada em julgado em razão da cláusula rebus sic stantibus demonstram a relevância e a importância da intervenção de um defensor no processo.

\footnotetext{
90 Antonio Magalhaes Gomes Filho, A defesa do condenado na execução penal, in Execução Penal, São Paulo: Max Limonad, 1987, p.41.

${ }^{91}$ Manoel Pedro Pimentel, Prisões fechadas e prisões abertas, Série Estudos Penitenciários. São Paulo:Cortez \&Moraes, 1978,1888, apud JUlio FABBRINI MiRABETE, Execução Penal... cit.,p. 73.

92 JUlio FABBrini MiRABETE, Execução Penal... cit.,p. 73.
} 
A exigência de defesa técnica para o apenado não pode ser suprimida ou preterida sob o argumento de que o Ministério Público pode atuar em favor do sentenciado, pois, na verdade, ele está atuando em prol da justiça. “O defensor poderá sempre pedir mais, pois é o único compromissado com a defesa. Assim, o MP tem poder de impulso para os incidentes da execução em favor do sentenciado (rectius, da justiça), mas é indispensável a intervenção do defensor quando haja possibilidade de modificação do título executivo ou de suas modalidades, estabelecendo-se o contraditório e a igualdade de armas (par condicio), antes de o juiz decidir.". 93

Em síntese, admitir a natureza jurisdicional da execução penal implica o reconhecimento do caráter contraditório do processo de execução penal, que por sua vez, implica "admitir ao condenado, principal interessado em todas as eventuais modificações da forma e quantidade da sanção punitiva, a possibilidade de propor a realização de provas, participar de sua produção, criticá-las e, eventualmente, oferecer contraprova, sempre que do procedimento possa resultar alteração do título executório penal, seja para concessão ou seja para a revogação de qualquer benefício.". ${ }^{44}$

A atuação de um defensor é de fundamental importância para o apenado. Se durante o processo de conhecimento já é comum o réu não ter condições financeiras de constituir advogado, na execução penal essa situação é agravada ${ }^{95}$, pois, justamente por ter sido condenado a uma pena privativa de liberdade, o preso terá que deixar o seu trabalho e a renda familiar diminuirá impossibilitando gastos com sua defesa. Justamente, por isso a assistência judiciária gratuita é de relevante importância.

\section{O juiz da execução penal}

Consagrada a execução penal como atividade jurisdicional, conclui-se que todas as decisões no curso do processo de execução da pena deverão ser proferidas por um Juiz de Direito, legítimo detentor do poder jurisdicional.

No entanto, nem sempre foi assim. Em um primeiro momento, competia ao Poder Judiciário somente apurar o delito e decidir pela condenação ou pela absolvição, não

\footnotetext{
93 AdA Pellegrini Grinover, Anotações sobre os aspectos processuais da Lei de Execução Penal, in Execução Penal, São Paulo: Max Limonad, 1987, p.17.

${ }^{94}$ Antonio Magalhaes Gomes Filho, A defesa do condenado na execução penal, in Execução Penal, São Paulo: Max Limonad, 1987, p.43.

${ }^{95}$ Considerando esta realidade, EDUARDO M. CAVALCANTI pondera que "se é deficiente a defesa do acusado na fase cognitiva do processo penal, essa é quase inexistente na execução penal.”. (O ministério público na execução penal, in Crítica à execução penal, $2^{\mathrm{a}}$ ed, Rio de Janeiro:Lumen Iuris, 2007, p.352.)
} 
desempenhando funções relativas ao acompanhamento do cumprimento da pena. A atuação dos juízes criminais exauria-se na sentença de condenação, e, a partir daí, as atividades fiscalizatórias na execução penal ficava sob responsabilidade do Poder Executivo. No Brasil, não havia previsão normativa sobre controle jurisdicional na execução penal, pois os "instrumentos legais que dispunham sobre as competências dos juízes criminais sequer faziam menção à participação jurisdicional no cumprimento da pena." 96 . De outro giro, "isso não significa que não existisse qualquer atuação do Judiciário no cumprimento da pena, até porque a partir da regulamentação do livramento condicional, em 1924, sua concessão passara a depender de uma decisão judicial. O que significa, no entanto, é que inexistia qualquer prática que pudesse refletir as noções de devido processo legal, controle jurisdicional, direitos e garantias individuais dos presos, no âmbito da execução penal. Nesse sentido, a atuação do juiz constituía-se em meramente corroboradora da atividade administrativa e em um apoio burocrático e técnico legal à mesma." 97.

No início do século XX, com o fortalecimento do pensamento por uma execução jurisdicionalizada, passou-se a ponderar sobre a necessidade de ter um juiz atuante no cumprimento da pena. A preocupação com a instituição do juiz da execução criminal é recente e se harmoniza com o movimento pelo reconhecimento dos direitos humanos. Nesse passo, o tardio reconhecimento dos direitos humanos retardou a intervenção do juiz no domínio penitenciário. ${ }^{98}$

A Itália foi o primeiro país a prever a criação de um juiz especializado na execução penal, denominado juiz de vigilância, a partir de seu Código de Processo Penal de $1930^{99}$, o que se revela muito interessante considerando ser a Itália governada pelo regime autoritário fascista nesta época. Justamente por isso, deve-se atentar que o juiz da execução penal foi intitulado como Giudice di Sorveglianza, o que revela que sua atuação era mais passiva, isto é, de apenas observar o pessoal administrativo. No entanto, o fato de prever um magistrado fiscalizador e autônomo à administração já representou um grande avanço.

\footnotetext{
${ }^{96}$ AlESSANDRA TEIXEIRA, Do sujeito ... cit., p.58.

${ }^{97}$ Idem, p.58.

98 Jason Albegaria, O juiz de execução penal, Revista do Conselho Nacional de Política Criminal e Penitenciária v.1 n.3, jan./jun. 1994, p 49.

${ }^{99}$ Alessandra TeIXEIRA, Do sujeito ... cit., p.58.
} 
No Brasil, a previsão de um juiz responsável pela execução da sentença condenatória seria feita de maneira bem singela e genérica com o Código de Processo Penal de $1941^{100}$, com abrangência nacional ${ }^{101}$.

A partir da década de 80, ante a nova sistemática instaurada pela Lei de Execução Penal, na qual o condenado passa a figurar como titular de direitos subjetivos ${ }^{102}$, o juiz passa a exercer um papel muito mais ativo, devendo acompanhar de maneira permanente e intensa a execução.

A efetiva judicialização consagrada pela Lei de Execução Penal confere posição de relevo à autoridade judiciária. Longe de prescrever uma tímida vigilância ou bases para um controle remoto, o diploma especifica concretamente as diversas hipóteses de atuação. ${ }^{103}$

A figura de um juiz com competências especializadas no âmbito da execução penal "significa muito mais do que mera localização burocrática dos autos na organização judiciária, visto que alça à condição de garantia da legalidade na execução." ${ }^{104}$. Dessa forma, o juiz da execução passa a não ser mais visto como um mero aplicador da sentença condenatória penal, mas sim como colaborador para garantir a ordem jurídica, promovendo a observância dos direitos fundamentais e, assim, contribuir para efetivação da Justiça.

O juiz dos tempos atuais não pode agir como mero aplicador da lei, nua e crua, de maneira objetiva, ao contrário a ele compete integrar a lei à realidade vivenciada pela sociedade à qual o ordenamento jurídico serve, afinal, "cumple papel preponderante el edifício mental del juez, pues es ilusorio para el hacedor de las leyes prever todos los conflitos sociales posibles para luego asignar a cada uno de ellos la solución normativa correspondiente." 105 Em complemento, importante atentar para "la necesidad de dinamizar y rescatar la importância que dentro del processo penal tiene la etapa de la ejecución de la pena y, consecuencialmente, el juez de ejecución de penas y medidas de seguridad - todos los jueces penales lo son -, desterrando la errônea y publicitada idea que el juez en esta es, simplesmente un contador de tiempo.". ${ }^{106}$

\footnotetext{
${ }^{100}$ Art. 668. A execução, onde não houver juiz especial, incumbirá ao juiz da sentença, ou, se a decisão for do Tribunal do Júri, ao seu presidente. (grifos nossos)

${ }^{101}$ Antes de 1941, competia aos Estados legislar sobre o direito processual.

102 Vide Art. $3^{\circ}$ da LEP “Ao condenado e ao internado serão assegurados todos os direitos não atingidos pela sentença ou pela lei. ”.

${ }^{103}$ ReNE ARIEL DOTTI, A lei de execução ... cit., p. 203.

${ }^{104}$ SidNEI AgOSTINHO BENETI, Execução penal... cit., p.67.

105 Mario Montes GiRALdo, Juez de ejecución de penas en el Estado Constitucional y princípios de favorabilidad, dignidad humana, libertad, igualdad, legalidad, debido proceso y presunción de inocência. Derecho Penal y Criminologia v.22 n.72, mayo/ago., 2001, p.57.

${ }^{106}$ Idem, p.56
} 
A competência é especializada, atribuída ao juiz da execução penal segundo as normas de organização judiciária, nos termos do dos artigos 65 e 66 da Lei de Execução Penal. Só por exceção, será o juiz do processo de conhecimento. ${ }^{107}$ Além disso, confere-se ao juiz da execução o poder de decisão, controle e inspeção.

No que tange ao poder decisório, o juiz da execução não é um autômato, compete a ele tomar decisões com o escopo de adequar o comando inicial às exigências da execução, contribuindo para a individualização do processo executório. Respaldado por este poder, o juiz pode decidir acerca da progressão ou regressão de regime, detração, remição, concessão ou revogação do sursis, concessão ou revogação do livramento condicional, declaração de extinção da punibilidade, neste último caso, desde que seja por fatos posteriores à decisão proferida no processo condenatório. ${ }^{108}$

O processo de execução penal não é estático, ao contrário, é dinâmico, e o juiz da execução é chamado frequentemente a exercer, em sua plenitude e em sua pureza, a função jurisdicional: e nem assim poderia deixar de ser, porquanto a sentença condenatória penal contém implícita a cláusula rebus sic stantibus, como sentença determinativa que é: o juiz fica, assim, autorizado, pela natureza mesma da sentença, a agir por equidade, operando a modificação objetiva da sentença sempre que haja mutação nas circunstâncias fáticas. ${ }^{109}$

O conteúdo da sentença serve como delimitação do direito de punir, porém, na execução penal, pode o título executivo ser adaptado a fatos supervenientes.

Ao magistrado é permitido tomar decisões que poderão afetar o comando condenatório, como, por exemplo, decidir sobre aplicação de lei mais benéfica superveniente, concessão de indulto, unificação de penas.

A sentença penal condenatória enquanto título rebus sic stantibus, pode ser modulada pelo juiz da execução "diante de fatos novos que não digam respeito à prova da infração penal (objeto de revisão criminal) ou à regularidade do procedimento (objeto de revisão criminal ou habeas corpus)." ${ }^{, 110}$.

O juiz da execução deve proferir decisões tendentes a garantir os direitos do preso e a evitar desvios no cumprimento da pena, afinal a ele cabe a incumbência de zelar para que

\footnotetext{
${ }^{107}$ ANTONIO SCARANCE FERNANDES, Execução penal... cit, p.75.

${ }^{108}$ A esse respeito, ANTONIO SCARANCE FERNANDES esclarece que o juiz da execução só pode declarar a extinção da punibilidade por fatos posteriores à decisão proferida no processo condenatório. Se a causa existia antes da sentença, competente para decidir a respeito seria o juiz do processo condenatório, ainda que dela não tivesse tomado conhecimento e, por isso, a desconstituição do provimento só pode ser obtida mediante revisão criminal ou habeas-corpus. (Idem, p.7)

${ }^{109}$ Ada Pellegrini Grinover, Antonio Magalhães Gomes Filho, Antonio SCarance Fernandes, A exigência... cit., p.4

${ }^{110}$ SidNeI AgOSTINHO BeNETI, Execução penal... cit., p.62.
} 
sejam respeitadas tais prerrogativas do apenado, uma vez que, investido na função, tem o dever de zelar pela proteção e guarda dos preceitos legais e constitucionais, atributo este de cunho obrigatório de todo magistrado dentro do Estado de Direito. ${ }^{111}$

Funcionalmente, o juiz age, dentro dos limites da sentença condenatória, para serem atingidos os escopos próprios da execução penal, principalmente o escopo de que o cumprimento da pena seja feito num itinerário crescente de individualização em consonância com os progressos de ressocialização apresentados. ${ }^{112}$

A mutabilidade deriva, pois, da necessidade de adequação do tratamento reeducativo ao desenvolvimento da personalidade do sentenciado no curso da execução penal. Nessa adequação pode haver progressão ou regressão no tratamento, com prejuízo para o recluso, o que não resolve o funcionário administrativo, mas somente o órgão judiciário, em razão de sua independência e imparcialidade. ${ }^{113}$

Em síntese, a sentença condenatória transitada em julgado fixa os limites decisórios do juiz da execução penal, porém, poderá este proferir resoluções que adaptem o comando inicial condenatório às exigências do cumprimento da pena imposta, ${ }^{114}$ ressalvando que as matérias que são proibidas ao exame do juiz da execução deverão ser atacadas em revisão criminal ou habeas corpus.

O juiz da execução detém ainda poder correcional em relação ao estabelecimento prisional. Para exercer os poderes correcionais a ele atribuídos o juiz deve, consoante positivado na Lei $\mathrm{n}^{\circ} 7.210 / 84$, visitar os estabelecimentos prisionais no mínimo uma vez ao mês. A exigência legal de visita constante implica a participação direta do juiz no cumprimento de pena e garante a fiscalização junto à administração nos presídios.

Em se tratando de pena privativa de liberdade, competência do Juízo das Execuções é firmada pelo local onde o preso se encontre cumprindo pena. Em regra, é da Justiça Estadual comum, pois os estabelecimentos estão, normalmente, sujeitos à sua jurisdição. Assim, se alguém for condenado pela Justiça Federal, mas estiver recolhido em estabelecimento sujeito à jurisdição da Justiça Estadual, esta é competente para a sua execução penal. O mesmo sucede quando se trata de condenado pela Justiça Militar.”. ${ }^{115}$

\footnotetext{
111 RICARDo LORENZI, A motivação judicial no âmbito da execução penal, Revista IOB de Direito Penal e Processual Penal v.7 n. 42, fev./mar. 2007, p.90.

${ }^{112}$ ANTONIO SCARANCE FERNANDES, Reflexos relevantes... cit., p.89.

113 JASON ALBERGARIA, O juiz de ... cit., p 46

${ }^{114}$ ANTONIO SCARANCE FERNANDES, Reflexos relevantes... cit., p.92.

${ }^{115}$ ANTONIO SCARANCE FERNANDES, Execução penal.. cit.,p.75.
} 
No sistema penitenciário brasileiro é corriqueiro que presos processados perante a Justiça Federal tenham a execução da pena tramitada pela Justiça Estadual, uma vez que muitos cumprirão pena em estabelecimento penal estadual. Tal fato sobrecarrega ainda mais os Juízos das Varas das Execuções Criminais, que em geral contam com poucos funcionários e magistrados para dar conta de levado número de processos provenientes de ambas as Justiças.

O número de juízes que atuam no âmbito da execução da pena é menor do que o dos juízes lotados nas Varas Criminais destinadas a apuração do delito, o que, a princípio, demonstra-se lógico, afinal, é possível que o processo de conhecimento tenha desfecho absolutório ou simplesmente termine antes de desenvolver-se completamente, ocorrendo, por exemplo, arquivamento, suspensão condicional, reconhecimento de nulidade, não chegando a ser imposta uma pena. Todavia, é bem verdade que no Brasil se processa muito e se condena também. Portanto, na prática, o parco número de magistrados dedicados à execução penal transformar-se em um fator problemático.

Não bastasse a insuficiência numérica de magistrados dedicados à execução, dos poucos magistrados que militam na área da execução penal, ínfima parte de fato tem vocação, preparo adequado e conhecimento para exercer a função. Não por despreparo para exercer a função jurisdicional em si, afinal, é fato que os magistrados são selecionados por meio de acirrado certame, mas é preciso reconhecer que o estudo dos temas da execução penal é tímido quando não preterido desde a formação acadêmica.

Nesse passo, muito revelador o relato do Juiz de Direito do Tribunal de Justiça do Distrito Federal e Territórios George Lopes Leite sobre o desafio de assumir uma Vara de Execuções Criminais, definindo, em suas próprias palavras, que "a designação como titular da Vara de Execuções Criminais de Brasília caiu-lhe como um petardo.”. Narra o magistrado que "o aprendizado da execução penal foi um processo maiêutico ${ }^{116}$. A perplexidade cedeu lugar à angústia, e essa angústia suscitava indagações cujas respostas nunca eram encontradas nos poucos livros disponíveis sobre o assunto. Árduo foi o caminho trilhado: cada problema, uma nova experiência; cada emoção, outra vivência. Aos poucos, o conhecimento foi-se completando, embora nunca tenha chegado à culminância.". 117

\footnotetext{
${ }^{116}$ A maiêutica é um método de ensino socrático no qual o professor se utiliza de perguntas simples que se multiplicam para levar o aluno a responder às próprias questões.

117 GEORGE LOPES LEITE, O papel... cit., p.58.
} 
Mais do que conhecimento técnico jurídico apontam-se como requisitos para ser juiz da execução da pena formação especializada, com ênfase nas ciências criminológicas e direitos humanos, e a vocação e entrega à missão. ${ }^{118}$

Todo juiz precisa ter potencialidades intelectivas, mas o juiz da execução precisa ir além. O articulista Jorge Raul Gil sintetiza com esmero os predicados que devem ser reunidos pelo juiz da execução: "Estos hombres, a quienes se les encomienda tan importante función, debem reunir un conjunto de virtudes, tales como conocimiento cabal de la problemática penitenciaria y del delincuente, experiência y honestidad. Pero, por sobre todas las cosas, deben reunir requisitos de capacitación e idoneidad y una gran vocación de servicio, sin escatimar esfuerzos para la reinserción del individuo en la sociedad, en interes de las personas privadas de la libertad y que va a redundar finalmente en el interes de la comunidad." $" 119$.

O tecnicismo deve ser complementado por uma formação mais interdisciplinar que viabilize uma interação do juiz com a realidade de seu tempo e do cárcere. Assim, o juiz da execução penal "deverá refletir constantemente sobre alguns dos incisos do art. $5^{\circ}$ da Constituição da República e da sua responsabilidade em não permitir sejam declarações retóricas e destituídas de consequência prática. Embora transitoriamente encarregado de fazer cumprir a condenação criminal, o juiz brasileiro nunca perde sua condição de juiz da liberdade. E a liberdade é o status natural do homem seu apanágio e exteriorização de sua dignidade. Sacrificá-la reclama estrita observância dos preceitos da lei.”." ${ }^{120}$

Pode-se afirmar que "especial talento se requer então do juiz da execução penal. Sensibilidade, formação humanística, profundo senso de solidariedade humana. Equilíbrio para poder ingressar nessa seara tão árida da delinquência, atentando para os direitos fundamentais de quem, por haver praticado delito, não perdeu sua dignidade humana. Sensatez para não transformar o preso numa vítima do sistema, esquecendo-se às vezes da vítima do crime e de sua família. Mas também não se convertendo num carrasco perpétuo de quem delinquiu, afligindo-o de forma permanente e considerando-o objeto da vindita estatal, não mais sujeito de qualquer direito.”. ${ }^{121}$

\footnotetext{
118 JASON AlBERGARIA, $O$ juiz de... cit., p 51.

${ }^{119}$ Jorge RAUL GIL, Análisis de la figura del juez de ejecución penal, Revista del Colégio de Abogados de la Plata. La Plata v.44.n.65, dic. 2004, p. 168.

${ }^{120}$ José RenAto NALINI, Pode o juiz melhorar a execução penal?, in - Execução penal - visão do TACRIM $S P, 1998$, p.137.

121 Idem, p.139.
} 
Diante da gravidade do problema da segurança pública e do sistema penitenciário é necessário que o juiz da execução esteja ciente de sua grande responsabilidade em exercer suas atribuições que, dentre outras, é promover o retorno paulatino dos apenados ao meio social e conciliá-la com a necessidade de proteger a sociedade. É preciso prestigiar a execução penal, aprimorar as pesquisas quanto aos temas que a permeiam e qualificar os juízes que irão atuar nesta área.

Reportando-se novamente ao relato do magistrado George Lopes Leite: "se os homens responsáveis pela aplicação da Justiça em nosso país, conscientes dessa dura realidade (a do cárcere) e de suas altas responsabilidades, puderem compreender a singular importância da Vara de Execuções Criminais, talvez as dificuldades do sistema penitenciário - decorrentes, em parte, do despreparo dos juízes da execução penal e da falta de meios adequados - possam ser mais bem enfrentadas. É imperioso e urgente preparar os juízes para essa difícil tarefa.". ${ }^{122}$

\subsection{Atuação do Juiz: sistema inquisitório versus sistema acusatório.}

Importante registrar que Lei de Execução Penal é considerada por alguns estudiosos como inquisitória, "pois a jurisdição executiva inicia-se de ofício, com a expedição da carta de guia pelo juiz. À continuação, atribui ao juiz ampla possibilidade de atuar ex officio, predomina a forma escrita dos atos, o contraditório e direito de defesa são bastante limitados (defesa técnica).". ${ }^{123}$

Por outro lado, há quem defenda que o fato do juiz poder atuar de ofício "não tem o condão de impor ao processo executório um revestimento inquisitório, afastando-o do respeito das garantias fundamentais.". 124

Para melhor entender a questão, deve-se refletir sobre os sistemas processuais penais: acusatório, inquisitório e misto.

Em breve explanação, no modelo acusatório as funções de acusar, defender e julgar estão distribuídas a três órgãos distintos (acusador, defensor e juiz), já no modelo inquisitório há coincidência subjetiva entre o órgão acusador e julgador, sendo a concentração dos poderes processuais a principal característica deste sistema. Outro ponto

\footnotetext{
122 GEORGE LOPES LEITE, O papel ... cit.,p.59.

${ }^{123}$ AURY LOPES JR, Revisitando o Processo... cit., p. 373.

${ }^{124}$ Marcos AleXAndre Coelho ZILli, A iniciativa instrutória do Juiz no Processo Penal, São Paulo: RT, 2003, p. 253.
} 
diferenciador de um sistema para o outro é a forma da gestão probatória, sendo que no sistema acusatório temos um juiz passivo, inerte, dependente da provocação das partes, enquanto no sistema inquisitório o juiz assume uma postura ativa e investigativa.

Nesse sentido, o sistema acusatório é identificado, sobretudo, pelo posicionamento passivo do juiz, tanto no que concerne ao impulso processual (ação penal) quanto à gestão da prova. Ao estar rigidamente separado das partes, adquire postura de espectador do jogo processual contraditório, cabendo tão somente à acusação e à defesa a atividade probatória. À oralidade e à publicidade do processo se agrega a necessidade de decisão orientada pelo princípio do livre convencimento. Por outro lado, no sistema inquisitório o juiz procederia ex officio à busca, instruindo o processo escrito secreto no qual a decisão é baseada em provas tarifadas ou na íntima convicção. ${ }^{125}$

Existe ainda o sistema misto que "incorporou aspectos tanto do inquisitório como do acusatório, motivo pelo qual se prefere denominá-lo de inquisitório reformado.”. ${ }^{126}$ Este sistema difundiu-se durante a expansão napoleônica pela Europa Continental, onde predominava o sistema inquisitório, o qual passou a sofrer influência das ideias iluministas. ${ }^{127}$ Uma característica interessante do sistema misto é que nele a jurisdição penal geralmente é exercida por tribunais, admitindo-se em algumas hipóteses a participação popular; os tribunais podem ser compostos por juiz leigos e profissionais ou apenas por juízes profissionais.

A consequência prática da adoção de um ou de outro modelo reflete-se no ativismo judicial durante a instrução probatória. Basicamente, a questão gira em torno do envolvimento do julgador na atividade instrutória e como isso afeta sua imparcialidade.

A delimitação das funções das partes no processo é essencial para equilibrar a relação estabelecida entre juiz, promotor, defensor e apenado. Quando se tem um juiz inquisidor, a imparcialidade estaria comprometida, pois "uma atuação positiva conduziria ao estabelecimento, ainda que inconsciente e não desejado, de valorações e diagnósticos preliminares sobre uma dada prova e, por consequência, na fixação de conclusões que assumiriam contornos de definitividade, impedindo, assim, o conhecimento e a assimilação de outras provas." $" 128$.

\footnotetext{
${ }^{125}$ SAlo De CARVAlho, Da necessidade da efetivação do sistema acusatório no processo de execução penal, in Crítica à execução penal, $2^{\mathrm{a}}$ ed, Rio de Janeiro:Lumen Iuris, 2007, p. 420.

${ }^{126}$ MARCOS AlEXANDRE COELHO ZILli, A iniciativa instrutória ... cit., p. 41.

${ }^{127}$ Idem, p. 37.

${ }^{128}$ Ibidem, p. 47.
} 
$\mathrm{O}$ ordenamento processual penal brasileiro prestigia o modelo acusatório, no entanto, como mencionado acima, alguns doutrinadores entendem que o processo de execução guarda alguns traços do modelo inquisitório, considerando que a jurisdição executiva inicia-se de ofício. Argumentam não ser incomum que o juiz aja sem qualquer provocação das partes, e que inclusive há discussão acerca do papel desempenhado pelo Ministério Público na execução penal, ou seja, se este atua como parte, ou como mero fiscal da lei. No último caso, o juiz poderia atuar independente de qualquer provocação, porque não haveria acusação.

Aquecendo a controvérsia, Aury Lopes Jr. alerta que "o grande problema do processo penal está nos seus dois extremos: no inquérito policial e na execução da pena. Ambos administrativos e inquisitivos, deixando o sujeito passivo em completo abandono, sendo tratado com objeto e sem as mínimas garantias.". ${ }^{129}$

De outro lado, Sidnei Agostinho Beneti acena que "do ponto de vista processual, o Juízo da Execução é o sujeito imparcial da relação jurídica do processo de execução, situando-se bem à moda do juiz da execução cível, quer dizer, tomando providências práticas visando ao cumprimento do julgado, com preservação do contraditório típico do processo de execução, mas, na execução penal, dotado de acentuada dose de poder inquisitivo, em virtude da obediência à regra da oficialidade, que lhe autoriza a busca da verdade material, no processo de execução.". ${ }^{130}$ Embora reconheça influência do poder inquisitivo na execução penal, para este autor o fato do processo de execução penal ser iniciado ex officio adequa-se à regra da obrigatoriedade da execução, e, portanto, não comprometeria a imparcialidade do juízo, esclarecendo que os provimentos ex officio são desprovidos de conteúdo material, fundados em pura normatividade formal. Aplicando esse raciocínio, sintetiza que "a instauração ex officio é mera decisão interlocutória de conteúdo formal, ou seja, de instauração de procedimento, sem comprometimento prévio com o sentido das decisões futuras, especialmente sentença." ${ }^{, 131}$.

Seguindo este pensamento, não seria o fato do juiz dar início por conta própria ao processo de execução que daria a tônica inquisitiva à execução penal. Ainda que superado este argumento, podem ser citados outros indicativos da vigência do sistema inquisitório na execução penal: o predomínio da forma escrita, a excepcionalidade de audiências e oitiva

\footnotetext{
${ }^{129}$ AURY LOPES JUNIOR, Revisitando o Processo... cit., p. 372.

${ }^{130}$ Sidnei AgOSTINHO BENETI, Execução penal... cit., p.69.

131 Idem, p.118.
} 
das partes, a não obrigatoriedade da presença do defensor, por falta de previsão legal expressa, e o papel exercido pelo juiz na gestão da prova.

Como já exposto acima, a jurisdicionalização da execução penal impõe obediência à regra do devido processo legal e seus corolários, dentre os quais, o contraditório e a ampla defesa. Assim, ainda que a defesa não venha indicada expressamente na Lei de Execução Penal, sua atuação no processo é exigência que decorre das garantias constitucionais inerentes ao devido processo legal.

Para Salo de Carvalho, se se quer realmente democratizar o processo de execução, é imprescindível reavaliar a posição do juiz, tornando-o garante em processo penal democrático regido pelos princípios do devido processo penal. ${ }^{132}$

De outro giro, para Marcos Zilli, não haveria a necessidade dessa reavaliação, pois a iniciativa instrutória do juiz, informada pelo devido processo legal de um Estado Democrático de Direito, não deve ser encarada como uma extensão da atuação repressiva de um Estado centralizado, mas, sim, como instrumento fundamental para respeito e cumprimento da própria igualdade. ${ }^{133}$ Por fim, consigna que não há "nada mais equivocado do que associar o 'poder-dever' instrutório do juiz com o aniquilamento do contraditório ou mesmo da ampla defesa" ${ }^{134}$, razão pela qual o processo executório não deve ser encarado como inquisitório.

Finalmente, após debater exaustivamente diversas questões teóricas e práticas ligadas ao processo de execução penal, as Mesas de Processo Penal da Faculdade de Direito da USP reconheceu a estrutura jurídico-processual tríplice do processo de execução conforme enunciado da Súmula $44^{135}$, fortalecendo a ideia de um processo de execução penal acusatório.

\footnotetext{
${ }^{132}$ Salo de CARVAlho, Da necessidade... cit, p. 425.

${ }^{133}$ Marcos AleXANDre CoElHo ZILli, A iniciativa instrutória ... cit., p. 253.

${ }^{134}$ Idem, p. 253.

135 “Como em todo processo entendido como relação jurídico-processual tríplice, o processo de execução penal é processo de partes, que assegura ao sentenciado as garantias do 'devido processo legal', decorrentes diretamente da Constituição, mesmo no silêncio dos Códigos."
} 


\section{CAPÍTULO III - PROVA PERICIAL E EXECUÇÃO PENAL}

\section{Conceito de prova pericial}

Define-se prova como meio de convencimento cuja finalidade é a formação da convicção do juiz acerca da veracidade de uma afirmação sobre um fato e que se presta à fundamentação das decisões judiciais.

$\mathrm{O}$ primeiro ponto a ser meditado quanto à prova pericial diz respeito à sua natureza jurídica. Parte da doutrina qualifica prova pericial como meio de que se serve o juiz para avaliar a prova, negando-lhe o caráter de meio de prova. ${ }^{136}$ No entanto, prevalece o entendimento doutrinário que a classifica como um meio de prova técnico ou científico que pretende atestar a existência de fatos cuja compreensão somente é possível a partir de conhecimentos específicos. Por esta razão é produzida por pessoa devidamente habilitada denominada perito, que "emite um juízo de valor sobre os fatos, externando sua impressão sobre a possibilidade de terem sido causados por outros acontecimentos e de virem a produzir outros" ${ }^{137}$.

A colheita de elementos de prova com o objetivo de comprovar a existência de um fato ou circunstância que seja pertinente para o deslinde de uma questão jurídica realizada por profissionais dotados de conhecimentos especializados e técnicos denomina-se perícia.

O laudo pericial é peça de instrução que expõe a atividade realizada pelos peritos, de maneira pormenorizada, circunstanciada, lógica e fundamentada, e deve conter os esclarecimentos necessários que permitam às partes um melhor entendimento sobre o evento em exame, como por exemplo, auxiliar na tipificação do fato ou comprovação da existência do apurado, e assim possibilitar que tracem suas estratégias, seja de defesa, seja de acusação, bem como oferecer ao juiz elementos materiais seguros que corroborem para a formação de sua convicção sobre um determinado fato, quando a prova depender do conhecimento técnico e científico que escape ao magistrado, em busca da verdade.

Perícia é um meio de prova, isto é um instrumento pelo qual o fato é introduzido no processo, enquanto o laudo é o elemento de prova, pois, de maneira simplista nada mais é do que a documentação da perícia. Trata-se de uma peça escrita, fundamentada, na qual os

\footnotetext{
${ }^{136}$ ADA PELlEGRINI GRINOVER. O conteúdo da garantia do contraditório, in Novas tendências do Direito Processual. Rio de Janeiro: Forense Universitária, 1990, p. 27.

${ }^{137}$ Gustavo HenriQue Righi IVahy Badaró, Direito Processual Penal, tomo I. Direito ponto a ponto. Rio de Janeiro: Elsevier, 2008, p. 225.
} 
especialistas expõem suas observações e estudos que fizeram, respondem, quando houver, os quesitos formulados pelas partes, e registram as conclusões da perícia.

A relação entre os conceitos de elemento de prova, fonte de prova, meio de prova pode ser descrita de maneira sucinta e objetiva da seguinte forma: "Perícia é um meio de prova, técnica ou científica, que tem por objetivo a obtenção de certo conhecimento relevante para a apuração de um fato (elemento de prova), a partir de um procedimento técnico realizado sobre pessoa ou coisa (fonte de prova). A conclusão do técnico ou profissional (conclusão probatória) é expressa num laudo (elemento de prova), que tem por finalidade (finalidade da prova) influir na formação da persuasão racional do juiz, em seu processo cognitivo de valoração (valoração da prova)."138.

Quando a solução da controvérsia sobre fato apurado em processo judicial depender de saberes que transcendem o patrimônio de conhecimento do juiz, ele necessitará de auxílio de especialistas com conhecimentos técnicos de outras áreas. Assim, a produção de prova pericial "será necessária quando a análise, avaliação, interpretação e conclusão referentes a um aspecto fático apenas for possível mediante a aplicação de conhecimentos especializados." 139 .

O cerne da prova pericial é o conhecimento técnico especial que determinada pessoa há de ter para identificar, constatar, apreender, compreender e interpretar determinados fatos que, por sua natureza, impõem esse tipo de habilitação, que escapa ao magistrado. $^{140}$

Como toda prova, a finalidade da prova pericial está intimamente atrelada a descoberta da verdade e visa sustentar uma decisão justa. Desse modo, "nos casos em que ao juiz faltem os conhecimentos técnicos ou científicos necessários para a apuração da verdade, deverá ele buscar suprir essa falta valendo-se do apoio do perito, pessoa que detenha tais conhecimentos e possa então viabilizar uma decisão justa e acertada." $" 141$.

\footnotetext{
${ }^{138}$ LUÍS FERNANDO DE MORAES MANZANO, Prova pericial: admissibilidade e assunção da prova científica e técnica no processo brasileiro. Dissertação de Mestrado. Faculdade de Direito da USP, São Paulo, 2010, p 25.

${ }^{139}$ ANDREAS EISELE, A prova pericial no processo penal e o sistema do livre convencimento motivado, Revista Dialética de Direito Processual, abr. 2003, p17.

${ }^{140}$ AdA PELlegrini Grinover, Prova pericial: conhecimento técnico especializado e perícia complexa, Revista da Associação Brasileira da propriedade intelectual $\mathrm{n}^{\circ}$ 89, jul./ago.2007, p.4.

${ }^{141}$ AlEXANDRE FreitAs CÂMARA, O escopo da prova pericial e critérios para a escolha do perito, Revista da Associação Brasileira da propriedade intelectual no 89, jul./ago.2007, p.16.
} 


\section{Produção de prova na Lei de Execução Penal}

A execução penal é jurisdicionalizada, dessa forma, deve ser desenvolvida por meio de processo judicial em que se garanta o exercício do contraditório e da ampla defesa, o que abarca a possibilidade de produzir provas.

A matéria sobre prova no processo de execução penal está disciplinada no artigo $196, \S \S 1^{\circ}$ e $2^{\circ}$, Lei de Execução Penal, que assegura a produção de prova, cuja necessidade ficará a critério do juiz. ${ }^{142}$

A julgar pelos dispositivos legais, pode-se notar que o legislador evitou instituir muitas regras na disciplina da prova, levando a crer que na execução penal não existe, propriamente, um procedimento instrutório, sendo a prova colhida de imediato, e se processando tudo de maneira rápida e simples.

Alguns enxergam no referido dispositivo legal, traços do sistema inquisitório no processo de execução penal, na medida em que se o juiz entender desnecessária produção da prova, “o juiz decidirá de plano, mas, entendendo indispensável sua realização (perícia ou depoimentos), ordenará sua produção, decidindo após sua produção. A concentração das hipóteses de avaliação, determinação, produção e inserção da prova no processo de execução pelo juiz transforma o processo em 'afazer terapêutico', em 'psicoscopia', desenvolvendo no julgador 'quadros mentais paranóicos' visto a distância com o procedimento dialético." 143

Entretanto, não é pelo fato de o legislador ter previsto a possibilidade de o juiz agir de ofício na produção da prova na execução penal que estaria eleito o sistema inquisitório. Ressalta-se que, assim como na execução penal, o Código de Processo Penal, nos moldes do artigo 156, inciso II, também prevê a possibilidade do juiz, de ofício, determinar, no curso da instrução, ou antes de proferir sentença, a realização de diligências para dirimir dúvida sobre ponto relevante. Em que pese existir essa previsão, Fernando Capez assinala que o sistema adotado pelo Código de Processo Penal, principalmente após a Reforma Processual de 2008, é o sistema acusatório, é não o inquisitivo, uma vez que a faculdade de produção de provas pelo magistrado é supletiva. Isto significa dizer que "somente em casos excepcionais, quando a dúvida persistir no espírito do magistrado, é que este poderá

142 Art. $196[\ldots]$

$\S 1^{\circ}$ Sendo desnecessária a produção de prova, o Juiz decidirá de plano, em igual prazo.

$\S 2^{\circ}$ Entendendo indispensável a realização de prova pericial ou oral, o Juiz a ordenará, decidindo após a produção daquela ou na audiência designada.

${ }^{143}$ Salo de CARVAlHo, Da necessidade ... cit., p. 425. 
dirimi-la, determinando as diligências nesse sentido. Essa pesquisa probatória a ser efetivada pelo juiz deve restringir-se a uma área de atuação por ele delimitada, com o fito de evitar a quebra de imparcialidade." ${ }^{\prime 14}$.

O mesmo raciocínio poderia ser estendido à execução penal, isto é, ainda que exista a previsão da produção da prova ex officio pelo juiz da execução, tal previsão indicaria apenas uma faculdade, utilizada nos casos em que o magistrado entender necessária e pertinente a produção de outras provas para o seu convencimento. É o que se daria nos casos da exigência dos exames criminológicos, consoante os enunciados da Súmula 439 do Superior Tribunal de Justiça e da Súmula Vinculante 26 pelo Supremo Tribunal Federal.

De outro giro, não deixando de considerar a regra da oficialidade que permeia a execução penal e autoriza o juiz da execução a tomar as providências para dirimir questões na busca da verdade, é certo que ao Ministério Público incumbe pleitear medidas judiciais (art. 68, II e III) ou tomar providências administrativas, previstas no art.68, I, e parágrafo único, da Lei de Execução Penal.

Da atenta análise do rol de atribuições previsto no artigo 68, da Lei de Execução Penal, extrai-se que compete ao Ministério Público requerer, dentre outras medidas judiciais, todas as providências necessárias ao desenvolvimento do processo executivo, nos termo da alínea "a", inciso II, do artigo 68 da Lei de Execução Penal. Ao utilizar o vocábulo "todas", sem dúvida, o legislador atribuiu ao Ministério Público uma vasta gama de possibilidades de atuação, podendo, de certo, promover diligências e requerer a produção de prova. No que tange aos benefícios da execução, o Ministério Público tem o poder de impulso para os incidentes de execução instaurados em favor do sentenciado.

Não podemos deixar de atentar também que o artigo 68, inciso II, da LEP dispõe que incumbe ao Ministério Público requerer, de modo a indicar que é o juiz que julgará a necessidade ou não daquela medida judicial. Evidente que isso se estende à temática da produção da prova, logo, é o juiz que fará o juízo de pertinência e relevância da prova.

À defesa técnica também se garante a possibilidade de propor a realização de provas, participar de sua produção, criticá-las e, se for o caso, oferecer contraprova, sempre que vislumbrar a possibilidade de alteração do título executório penal em favor do apenado.

Coerente, no entanto, pensar que a verdadeira intenção do legislador ao redigir o artigo $196, \S 1^{\circ}$, da LEP, que expressa que caso seja desnecessária a produção de prova, o

\footnotetext{
${ }^{144}$ Fernando CaPeZ, Curso de Processo Penal, $18^{\mathrm{a}}$ ed, São Paulo: Saraiva, 1996, p.381.
} 
juiz decidirá de plano, não tenha sido a de estabelecer um sistema inquisitório, mas, ao contrário, indicar que o processo de execução deve se materializar por um procedimento célere e prático. ${ }^{145}$ Percebe-se, portanto que optou o legislador confiar na imparcialidade do julgador em troca da celeridade processual.

A ideia está em consonância com os direitos fundamentais do sentenciado que não pode sofrer com a delonga no desenvolvimento do processo executório, sob pena de cumprir uma pena mais rigorosa do que lhe foi imposta.

De fato, o corriqueiro é que os incidentes de execução já sejam formados com todos os elementos, geralmente documentais, suficientes para formar o conhecimento judicial, dispensando-se, dessa forma, a necessidade de provas mais elaboradas, podendo-se passar para ao julgamento. Porém, pode haver situações em que seja necessária a elaboração de prova oral, como, por exemplo, a oitiva do sentenciado nos casos de regressão de regime ante a prática de fato definido como crime doloso ou falta grave, nos termos do artigo 118 , inciso II, $\S 2^{\circ}$, da LEP, ou prova pericial, como, por exemplo, o exame criminológico elaborado nos incidentes formados para a concessão de benefícios.

Tentou-se, é verdade, simplificar a comprovação do requisito subjetivo, alterandose o artigo 112, da LEP, por meio da Lei $\mathrm{n}^{\circ}$ 10.792/03, exigindo-se somente um atestado de boa conduta carcerária, substituindo a prova pericial por uma prova documental, de modo a preservar a praticidade inerente ao processo de execução. Todavia, a mudança não foi de aceitação pacífica, continuando-se a exigir, a critério do juiz, a elaboração de laudos periciais para apuração do mérito do apenado para fins de benefícios.

\section{3. Ônus da prova na execução penal}

O ônus da prova, em síntese, pode ser encarado como regra de julgamento que orienta o juiz na resolução da demanda em caso de ausência ou insuficiência de prova de algum fato para formar seu convencimento.

\footnotetext{
${ }^{145}$ Nas palavras de SIDNEI AgOSTINHO BENETI "o procedimento constante da lei (LEP, arts.194 a 197) ostenta o mérito da praticidade. É simples, não fragmentado em múltiplos atos processuais e, sobretudo, é flexível, a ponto de, como se disse, servir de parâmetro às diversidades formais. Sendo comum, pode ser inserido na modalidade de procedimento acelerado, ou seja, procedimento que, diante da presença, nos autos, dos elementos informativos essenciais ao conhecimento, fornece imediato atalho para a sentença, mediante a supressão de formalidades reservadas para casos em que necessária maior amplitude de conhecimento processual[...]". (Execução penal... cit., p.112).
} 
A discussão acerca do ônus da prova se demonstra importante, pois é por intermédio das regras de distribuição do ônus da prova que será firmada a orientação de como o juiz deve decidir em caso de dúvida sobre fato relevante. Evidente que essa discussão é mais comum no processo de conhecimento, no qual o âmbito da dúvida é bem mais largo do que no processo de execução penal. No entanto, é fato que no processo de execução penal as dúvidas também podem acometer o julgador, principalmente nos incidentes de execução, no qual o magistrado exerce atividade tipicamente cognitiva.

Mesmo que na execução penal exista a possibilidade da produção ex officio da prova, gerando margem para a discussão acerca do modelo de processo adotado, se inquisitório ou acusatório, verifica-se que "em qualquer tipo de processo, tenha ou não o juiz poderes instrutórios, sempre será necessária a existência de uma regra de julgamento que permita ao magistrado decidir quando não tiver certeza sobre fato relevante. Se as partes não levarem ao processo as provas necessárias para o esclarecimento da verdade, o juiz poderá determinar de ofício a produção daquelas que entender pertinentes e relevantes. Contudo, mesmo que o juiz seja dotado dos mais amplos poderes de investigação, ainda assim poderá ocorrer que, ao final do processo, não tenha sido atingida a certeza. Ao término da instrução, o resultado poderá ser a dúvida. Em suma, mesmo nos processos em que o juiz esteja investido de poderes para determinar a produção de provas ex officio, será necessária a existência de regras de julgamento para o caso de dúvida sobre fato relevante, que sempre poderá ocorrer."146.

No processo penal, em razão do in dubio pro reo, compete à acusação provar os fatos alegados, de modo que se a acusação não conseguir produzir tais provas, e o acusado negar ou calar, a absolvição é medida que se impõe.

O princípio do in dubio pro reo é decorrência lógica da garantia constitucional da presunção de inocência. Na lição de Gustavo Badaró, não há que se falar em presunção de inocência na execução penal, pois, obviamente, já há um condenado com decisão transitada em julgado. Assim, não se aplicaria o in dubio pro reo no processo de execução penal. $^{147}$

Em oposição, Aury Lopes Junior afirma que "o princípio in dubio pro reo é perfeitamente invocável no processo de execução, especialmente em momentos críticos de valoração, como ocorrem nos exames criminológicos. Se não houver consenso na equipe

\footnotetext{
${ }^{146}$ GuStavo HenRIQUe Righi IVAhy BADARÓ, Ônus da prova no processo penal, São Paulo: RT, 2003 p.237. ${ }^{147}$ Idem, p. 408 .
} 
de observação ou houver laudos divergentes, está criada a dúvida, que necessariamente deve ser resolvida em benefício do apenado, reconhecendo-se o direito pleiteado (progressão, livramento condicional, etc.). Da mesma forma, se o juiz entender que os argumentos invocados para desautorizar a medida forem frágeis ou despidos de suficiente lastro, deve pender a balança em benefício do apenado."148.

Além das divergências doutrinárias acerca da incidência do in dubio pro reo sobre o processo de execução da pena, formou-se o entendimento, principalmente jurisprudencial de que no âmbito da execução penal vige o princípio diametralmente oposto, ou seja, o princípio do in dubio pro societate ${ }^{149}$. Assim, incumbiria ao condenado demonstrar que não irá infringir as regras do convívio social novamente e que é merecedor da confiança do Estado. Portanto, a atribuição do ônus da prova ao sentenciado seria decorrência lógica desse raciocínio. ${ }^{150}$

Esse posicionamento sofre críticas consubstanciadas no argumento de que "dar por prevalentes os interesses sociais na execução penal é negar vigência ao princípio da individualização da pena e às garantias constitucionais e usar o preso para dar satisfação à sociedade, ignorando sua individualidade e dignidade. Dessa forma, falar que na execução penal vige o in dubio pro societate é ignorar por completo que os princípios consagrados na Constituição se estendem à execução penal.". ${ }^{151}$

Nessa linha, dúvida quanto a fato relevante não pode servir de pretexto para indeferir as pretensões dos sentenciados, ao contrário, deve ser relevada pelo juiz da execução, uma vez que a legislação deu instrumentos ao magistrado para reparar possível equívoco na concessão de progressão de regime ou livramento condicional, tais como os institutos da regressão de regime de cumprimento de pena e da suspensão cautelar ou da revogação do livramento condicional. ${ }^{152}$

\footnotetext{
${ }^{148}$ AURY LOPES JUNIOR, Revisitando o Processo... cit., p. 393.

${ }^{149}$ Entenda-se como a preponderância do interesse de uma determinada coletividade ao direito de liberdade de pessoa individualmente considerada.

150 Nessa toada, já se pronunciou o antigo Tribunal de Alçada paulista: "a liberdade antecipada de criminosos, facultada pela lei somente pode ser concretizada se houver razoável certeza, apoiada em pareceres técnicos, de que os mesmos não voltarão a delinquir, vez que, entre o direito, em tese, que um sentenciado de alta periculosidade e inadaptado à vida social possui de ser colocado em liberdade, antes do prazo fixado na sentença, e o direito concreto que tem a sociedade de viver em segurança, opção indiscutivelmente deve favorecer a última."(RJDTACRIM 20/36)

${ }^{151}$ CARMen SILVIa de Moraes BARros, A individualização da pena na execução penal, São Paulo: RT, 2001, p. 151.

152 AleXANDRE ORSi NeTTO, A falácia do in dúbio pro societate como princípio no processo de execução criminal, Boletim IBCCrim n. 204, p. 14-15.
} 
Com efeito, negar a vigência do in dubio pro reo na execução penal, não significa necessariamente admitir a incidência do in dubio pro societate, cuja existência enquanto princípio inclusive é muito questionada.

Partindo da premissa da não incidência do in dubio pro reo, continua a ser necessário estabelecer regra de julgamento para orientar o magistrado em caso de incerteza no âmbito da execução penal.

Uma solução seria pautar-se em quem alegou o fato que se mostrou incerto, aplicando-se a regra do artigo 156, do Código de Processo Penal que prevê que a prova da alegação incumbirá a quem a fizer.

No que tange a esta regra, esclarece Fernando Capez que "a prova não constitui uma obrigação processual e sim um ônus, ou seja, a posição jurídica cujo exercício conduz seu titular a uma condição mais favorável.”. Acrescenta que diferente da obrigação, na qual a parte tem o dever, "no ônus o adimplemento é facultativo, de modo que o seu não cumprimento não significa atuação contrária ao direito. Neste último caso, contudo, embora não tendo afrontado o ordenamento legal, a parte arcará com o prejuízo decorrente de sua inação ou deixará de obter vantagem que adviria de sua atuação.". ${ }^{153}$

$\mathrm{Na}$ expressão de Nucci, o ônus da prova deve ser compreendido como "a responsabilidade da parte, que possui o interesse em vencer a demanda, na demonstração da verdade dos fatos alegados, de forma que, não o fazendo, sofre a "sanção processual", consistente em não atingir a sentença favorável ao seu desiderato. ${ }^{\prime 154}$.

Na síntese de Afrânio Silva Jardim, “ônus da prova é a faculdade que tem a parte de demonstrar no processo, a real ocorrência de um fato que alegou em seu interesse, o qual se apresenta como relevante para o julgamento da pretensão deduzida pelo autor da ação penal.". 155

Dessa forma, parte-se da premissa de que o maior interessado em que o juiz se convença da veracidade de um fato é quem deve se incumbir do ônus probatório. No caso do pedido de progressão de regime e livramento condicional o principal interessado seria o próprio executado, devendo ele demonstrar, por meio de provas, preencher os requisitos legais. ${ }^{156}$

${ }^{153}$ FERNANDO CAPEZ, Curso de ... cit., p.379-380.

154 GUILHERME De SoUZA NUCCI, Provas no processo penal, $2^{\mathrm{a}}$ ed. São Paulo:RT 2011, p.26.

155 AFRÂNIO SILVA JARDIM, O ônus da prova na ação penal condenatória, Revista de Processo $\mathrm{n}^{\circ}$ 47, jul./set. 1987, p.262.

156 "Em situação como a da espécie, não é a sociedade que deve dar uma oportunidade ao sentenciado, mas este sim, é que deve dar à sociedade a certeza de que está subjetivamente se redimindo dos atos ilícitos 
Deve-se registrar que os pedidos de progressão ou concessão de benefícios durante a execução não são de iniciativa exclusiva do sentenciado e de seus defensores. Os incidentes de execução podem ser abertos a pedido do Ministério Público que tem como uma das funções impulsionar esses expedientes, ou por ordem do magistrado que também deve zelar pelo correto cumprimento da pena, portanto, se perceber que o sentenciado já tem o lapso temporal necessário para progredir ou ser beneficiado, deve ordenar a formação do expediente. Assim, esse ônus da prova não seria absoluto do sentenciado, uma vez que o ônus da prova incumbe a quem alega. Nesses termos o ônus da prova é de quem der ensejo à abertura do incidente.

Considerando essa peculiaridade da execução penal de que os pedidos de benefícios podem ter sido suscitados tanto pelo condenado, quanto pelo Ministério Público mais tomentosa se torna apontar a solução para o ônus da prova. A situação se agrava nos casos em que os expedientes são instaurados ex officio pelo juiz da execução, como faculta o artigo 195, da Lei de Execução Penal. Nesse caso, nas palavras de Gustavo Badaró, seria absurda a conclusão de que ônus da prova incumbiria ao juiz! ${ }^{157} \mathrm{O}$ juiz não tem ônus, uma vez que, como sujeito imparcial, não possui interesse no processo, mas sim o dever funcional de decidir de maneira justa.

Insta salientar que geralmente nos pedidos do Ministério Público e na ordem do Juiz, não se encontra propriamente uma alegação de que o sentenciado faz jus ao benefício, mas sim um pedido ou uma ordem para se apurar as condições. Já nos expedientes promovidos pelo próprio sentenciado ou pelo seu defensor é mais corriqueiro se deparar com a afirmação de que o condenado preenche o lapso temporal (requisito objetivo) e tem mérito (requisito subjetivo), sendo mais natural, afirmar que o ônus da prova compete ao sentenciado nesses casos.

Poderia pensar-se que o deslinde da questão repousaria na questão do interesse. No entanto a alegação de que o sentenciado é o principal interessado na concessão do benefício esbarra na noção de que ao Estado também interessa reintegrar de maneira adequada e segura os condenados, de modo a bem prestar a sua jurisdição, e para isso deve ter a certeza de que aquele sentenciado reúne as condições para retornar, ainda que paulatinamente, à sociedade.

praticados, para ter méritos pessoais a uma situação prisional mais favorável.”.(TJSP, Agravo em Execução no 216.346-3/0, Rel. Des. Raul Motta)

${ }^{157}$ Gustavo HenriQue Righi IVAHY BADARó, Ônus da prova ... cit., p.411. 
Assim, o interesse da coletividade não poderia ser utilizado para obstar o deferimento dos institutos de reinserção social ao condenado, pois o interesse último da sociedade é a ressocialização do apenado, e isso só ocorrerá de maneira correta e segura, através do retorno paulatino do sentenciado ao meio social. Negar os benefícios com base no argumento de que na dúvida deve prevalecer o in dubio pro societate, revelaria uma incoerência, pois uma hora ou outra o condenado será libertado, e caso não tenha sido lhe dado a oportunidade da colocação gradual em liberdade, será devolvido à sociedade um indivíduo dessocializado, o que sem dúvida trará mais malefícios à coletividade, sendo contrário ao interesse social.

Desse modo, nem mesmo a regra do interesse seria capaz de solucionar a impasse do ônus da prova na execução penal, pois se o sentenciado tem interesse no benefício pleiteado, o juiz e o Ministério Público, enquanto representantes do Estado, também tem interesse no fiel e exato cumprimento da pena. ${ }^{158}$

Reconhecendo ser a questão do ônus da prova na execução penal tema de difícil solução, não havendo nenhuma orientação na Lei de Execução Penal de como o juiz deve proceder para a resolução da dúvida sobre fato relevante no âmbito da execução da pena, Gustavo Badaró sugere como solução que a decisão judicial seja tomada segundo o favor rei. Acrescenta o autor que o princípio do favor rei não deve ser confundido com o princípio do in dubio pro reo, uma vez que não há que se falar em presunção de inocência em sede de execução penal. Esclarece que o favor rei é princípio mais amplo, que permeia o direito penal e o processo em todos os seus momentos, mesmo nas hipóteses em que não tem incidência o in dubio pro reo. ${ }^{159}$

\section{Valoração da prova pericial}

Valorar a prova pericial não se revela uma tarefa fácil, pois justamente por não ser dotado de certos conhecimentos técnicos é que o juiz determina, de ofício ou a pedido das partes, a produção da prova pericial com a finalidade de aclarar dúvidas sobre determinado ponto em que é necessária a análise por expertos.

Aparentemente, instaura-se situação paradoxal, pois justamente por não possuir conhecimentos técnicos especializados necessários para a correta apreciação de uma

\footnotetext{
${ }^{158}$ Idem, p.411.

${ }^{159}$ Ibidem, p.411.
} 
questão é que o juiz recorre aos peritos, no entanto, por outro lado, não há uma delegação da decisão ao experto, a menos não deveria haver. Com relação a este impasse, bem anota Ada Pellegrini Grinover: "é inevitável a indagação: como pode o juiz, que se presume desconhecer a matéria técnica especializada (razão pela qual determinou a prova pericial), controlar o conteúdo do trabalho do perito, diante de tal desconhecimento? Como pode o juiz valorar uma prova cuja substância, por definição, é para ele estranha?". ${ }^{160}$

$\mathrm{O}$ perito tem por função informar e assessorar o juiz, utilizando-se de seus conhecimentos científicos, conhecimentos estes que o juiz pode carecer, mas jamais deve substituir o magistrado. O objetivo é ajudar o juiz, orientando-o no ofício jurisdicional, robustecendo seus conhecimentos fáticos, fornecendo-lhe elementos para proferir uma decisão justa a partir da valoração daquilo que foi informado pelo perito, uma vez que "la función del perito es la de proporcionar datos para que el Juez o Tribunal, valorándolos, puedan formar su juicio com conhecimento de causa, y dictar em su día uma sentencia justa.". 161

O perito, processualmente definido como um auxiliar da Justiça, é um profissional que emite, de maneira imparcial, manifestações técnicas, colhendo, observado ou analisando dados que requerem conhecimento de algumas regras de determinado ramo científico que ele domine, mas o magistrado não. Aquilo que o perito examina, por sua vez, deverá ser valorado pelo Juiz.

Alerta Antonio Magalhães Gomes Filho que o uso cada vez mais frequente e necessário de provas periciais em processos judiciais tem como risco inerente de transformar o juiz e as partes em destinatários passivos de informações incompreensíveis, cuja idoneidade para a reconstrução dos fatos nem sempre pode ser concretamente verificada. Tal fato leva a progressiva perda da eficácia da prova pericial, pois nem sempre o profissional do direito possui conhecimentos suficientes até mesmo para exercer algum tipo de controle sobre aquilo que é afirmado pelo perito. ${ }^{162}$

O grande desafio da valoração da prova pericial é o juiz não se tornar refém das conclusões dos peritos, pois uma vez que não tem conhecimento técnico para analisar a questão sem o auxílio de especialistas, também não o tem para refutar o laudo. O que se observa na prática é o acolhimento acrítico dos laudos periciais.

\footnotetext{
160 AdA PELlegrini GrinOVER, Prova pericial... cit.p.4.

161 JUAN-FELIPE HIGUERA GUIMERÁ. La prueba pericial psiquiátrica em los procedimentos judiciales penales y la medicina forense em España: uma respetuosa llamada urgente de atención, La Ley Penal: revista de derecho penal, procesal y penitenciário n.24.v.3, 2006, p.24.

${ }^{162}$ Antonio Magalhães Gomes Filho, Provas - Lei 11.690, de 09.06.2008, p.274.
} 
Com relação a este assunto, importante alertar que embora o perito "funcione como mero auxiliar do juiz - que é e continua a ser o peritus peritorum - e, portanto, não tenha ele próprio o poder de decidir, o experto desempenha relevante papel nas informações que fornece ao magistrado". 163

A determinação da produção da prova pericial está voltada à busca e ao recolhimento de elementos úteis para o melhor acertamento fático, todavia, ainda mais quando versa sobre ciências não exatas, a prova pericial não deve ser tomada como uma prova absoluta, não estando o juiz adstrito a ela. Deve-se ter a consciência de que o laudo pericial é apenas "um dos elementos de prova que o juiz valora para atingir o resultado da prova. Não tem valor definitivo, mas relativo. O juiz pode rechaçar a conclusão dos técnicos e, inclusive, ordenar a realização de nova perícia. Assim, por exemplo, se o perito propõe-se a fazer apreciações e conclusões pessoais, é razoável que o juiz acoime o laudo de tendencioso, destitua-o e determine a realização de nova perícia, ou simplesmente, à luz de outros elementos de prova existentes nos autos, conclua por resultado diverso daquele proposto pela prova pericial". 164

O laudo pericial inconclusivo, subjetivo ou ilógico deve ser dado como imprestável, perdendo o valor de prova, não podendo ser adotado como fundamento da decisão judicial, uma vez que se trata de uma "não-prova", pois não se pode " tomar como prova pericial o que juridicamente não o é e, muito menos, se admite ter como provado o fato que só na perícia imprestável se apoia". ${ }^{165}$

Nesse ponto, salutar a reforma processual penal de 2008 que passou a prever a possibilidade da indicação do assistente técnico pelas partes, permitindo a existência de verdadeiro debate acerca das provas técnicas.

O perito, sujeito processual imparcial, visa tão somente auxiliar o Juízo, no qual o juiz deposita sua confiança, no sentido de que aquele experto nomeado efetivamente conhece e domina determinada área do saber necessária à elucidação da controvérsia. A manutenção da equidistância do perito pode ser considerada a maior garantia de que seu trabalho é apto a embasar a decisão que dirima a controvérsia. ${ }^{166} \mathrm{O}$ assistente técnico já

\footnotetext{
${ }^{163}$ ADA PELLEGRINI GRINOVER,Prova pericial... cit..p.9.

${ }^{164}$ Luís FERnANDO DE Moraes MANZANO, Prova pericial... cit., p. 23.

${ }^{165}$ HuMBERTO THEODORO JÚNIOR, Admissibilidade da prova pericial complexa. Direito à prova e garantias processuais constitucionais, Revista da Associação Brasileira da propriedade intelectual $\mathrm{n}^{\circ}$ 89, jul./ago. 2007, p.70.

166 ADA PELlegrini GrinOver, Prova pericial... cit.,p.5
} 
não goza da mesma imparcialidade, uma vez que é contratado por uma das partes, da qual deve defender os interesses, recebendo delas a confiança.

Assim como o perito, o assistente técnico é pessoa dotada de conhecimentos técnicos, científicos ou artísticos, que traz ao processo informações especializadas, relacionadas ao objeto da perícia. ${ }^{167}$ Contudo, diferentemente do perito que deve guardar imparcialidade, o assistente é um sujeito de prova que atua no interesse da parte que o indicou. ${ }^{168}$

Considerando que em muitos casos a prova pericial é determinante para a motivação da sentença demonstra-se relevante a previsão legal do assistente técnico, pois a indubitável capacitação técnica do perito judicial pode não se revelar na prática, seja por falta de atualização, seja por falta de recursos materiais e humanos postos a disposição do auxiliar da Justiça. Desse modo, o bom resultado da perícia fica prejudicado, e, sem o pertinente questionamento do desempenho técnico das funções periciais, a prova pericial acaba sendo acolhida de maneira acrítica.

Ao prever a possibilidade de atuação do assistente técnico no processo penal, a Lei n $11.690 / 08$ viabilizou o pleno exercício do contraditório em relação à prova pericial e contribuiu para a melhor formação do convencimento judicial, aumentando as chances de ser proferida decisão mais acertada.

O assistente técnico, como conhecedor de determinado ramo da ciência que escapa ao juiz e às partes, poderá melhor interpretar o laudo feito pela perícia oficial, em favor da parte que representa e fornecer ao magistrado outra visão sobre a questão apurada. Muitas vezes as conclusões dos laudos periciais oficiais são aceitas como definitivas pelo magistrado porque este não entende o que lá está escrito.

Convém frisar que, para que a prova pericial possa cumprir corretamente sua função, atingir seus objetivos, devem os juízes - e as partes - conhecer não somente os rudimentos da ciência do perito, mas também sua linguagem, que é sua ferramenta lógica, suas próprias limitações na ciência, bem como sua ética profissional. A perícia, pois, necessita ser compreendida pelo juiz para poder ser valorada corretamente e ofertar a necessária segurança científica para a qual foi convocada, não podendo ser reduzida a um estéril jogo de palpites ou possibilidades, pena de configurar-se uma contraditio in re ipsa

\footnotetext{
167 Antonio Magalhães Gomes Filho, Provas - Lei 11.690, de 09.06.2008, in As reformas penais no Processo Penal As novas Leis de 2008 e os Projetos de Reforma. São Paulo; RT, 2008, p.274.

${ }^{168}$ Idem, p. 278.
} 
(contradição em si mesma). ${ }^{169}$ Nesse rumo, o assistente técnico tende a desempenhar um papel de relevo quanto ao esclarecimento dos fatos e à formação do convencimento do magistrado.

No processo de execução penal a participação do assistente técnico ainda não foi alvo de análise profunda, até mesmo por conta da atualidade da alteração do Código de Processo Penal, não havendo muitos pronunciamentos da doutrina e da jurisprudência a respeito. Por ora, não há nenhum dispositivo na Lei de Execução Penal, que legitime a participação do assistente técnico e regule sua atuação no processo executório. Desse modo, evidente, que não é pacífico a extensão da figura do assistente técnico para a execução penal.

Sendo o processo de execução penal jurisdicionalizado, e não sendo o apenado mero objeto do autoritarismo estatal, mas sujeito de direitos, ele tem o direito de participar das decisões judiciais que lhe alcancem. Assim, tem o "direito de refutar e contraditar juízos de valoração negativos feitos contra ele". ${ }^{170}$

A admissão do assistente técnico é, em si, boa providência para a execução penal, assim como o é no processo de conhecimento, porque, além de dar maior efetividade ao princípio do contraditório, possibilita ao juiz acesso a mais informações que lhe permitirá decidir pelo acolhimento ou rejeição do laudo oficial, cotejando-o com os dados trazidos por estes expertos particulares, contribuindo para o processo intelectual do juiz na formação da decisão.

\footnotetext{
${ }^{169}$ EDILSON MOUGenOt BONFIM, Curso de processo penal, $5^{\mathrm{a}}$ ed., São Paulo: Saraiva, 2010, p.365.

${ }^{170}$ AURY LOPES JUNIOR, Revisitando o Processo ... cit., p. 395.
} 


\section{CAPÍTULO IV - O EXAME CRIMINOLÓGICO}

\section{Institucionalização do exame criminológico ${ }^{171}$}

No Brasil, o instituto do exame criminológico se fortaleceu com a edição da Lei de Execução Penal, na medida em que a reforma penal de 1984, “identificada integralmente com o moderno Direito Penal da culpabilidade, comprometeu-se com a execução da pena privativa de liberdade cientificamente orientada". ${ }^{172}$

A novel legislação atribuiu grande valor as perícias criminológicas com o intuito de promover, em um primeiro momento, uma individualização da forma do cumprimento de pena, traçando um programa ressocializador de acordo com as peculiaridades da personalidade do apenado. Os diagnósticos serviriam para estabelecer os parâmetros do tratamento penal a ser aplicado.

De acordo com o item 31 da Exposição de Motivos da Lei de Execução Penal, a gravidade do fato delituoso ou as condições pessoais do agente, determinantes da execução em regime fechado, aconselham o exame criminológico, que se orientará no sentido de conhecer a inteligência, a vida afetiva e os princípios morais do preso, para determinar a sua inserção no grupo com o qual conviverá no curso da execução da pena.

Dessa feita, a ideia que permeia a instituição do exame criminológico é a de que ele seja uma importante ferramenta para aperfeiçoar a execução penal, permitindo que o condenado seja submetido ao programa individualizado de cumprimento de pena e assim garantir os melhor resultados para a reinserção social do cativo.

Ademais, o exame criminológico também é encarado como relevante instrumento de auxílio para decisões judiciais nos incidentes de execução, a fim de garantir maior acerto na medida a ser aplicada pelo Juízo.

\footnotetext{
${ }^{171}$ ALESSANDRA TEIXEIRA em sua dissertação de mestrado ao analisar o advento da prisão reflete que a partir do século XIX a ideia da pena centra-se no indivíduo, "não por suas ações concretas, mas por aquelas que poderiam ser cometidas - constituindo-se - em torno do sujeito a ideia de periculosidade[...']". Diante disso, o direito punitivo passa a ser influenciado por ciências humanas, como antropologia, psicologia, medicina social e psiquiatria. É nesse contexto que surge a criminologia como um saber especializado sobre o crime e o criminoso. (Do sujeito... cit., p.20.)

${ }^{172}$ CezAR ROBERTO BitTEnCOURT, Regimes penais e exame criminológico. Revista dos Tribunais, v. 77, n.638, dez. 1998, p.266.
} 


\section{Definição}

O exame criminológico constitui importante ferramenta para concretizar a individualização da pena na fase executória e é trabalho eminentemente técnico, voltado para a revelação o tanto quanto possível exata dos antecedentes do sentenciado, da conduta delinquente e da dinâmica do ato criminoso. ${ }^{173}$

Para Cezar Roberto Bittencourt, exame criminológico é a perícia destinada a apurar as condições pessoais nas quais o sentenciado cometeu o delito, a fim de obter elementos para o diagnóstico da conduta delinquente e o prognóstico de reincidência. Trata-se de estudo interdisciplinar, no qual se realiza a pesquisa dos antecedentes pessoais, familiares, sociais, psíquicos, psicológicos do condenado, para a obtenção de dados que possam revelar a personalidade do mesmo. ${ }^{174}$

De acordo com Alvino Augusto de Sá, o exame criminológico pode ser definido como multidisciplinar, já que faz convergir todos os informes para uma síntese essencialmente médica, ou médico-psicológica e que nada mais é do que uma classificação de doenças ou desvios de caráter, aplicada à conduta criminosa. ${ }^{175}$ Todavia, em outra obra o autor acrescenta que o trabalho da equipe criminológica, mais do que multidisciplinar, é interdisciplinar. Ou seja, mais de que simples junção de informações provenientes de diversas áreas profissionais, ele supõe o inter-relacionamento dessas informações, devidamente discutidas e sopesadas sob o enfoque criminológico, visando uma conclusão fundamentada em elementos de convicção. ${ }^{176}$

A interdisciplinaridade é característica essencial do exame criminológico e diz respeito à interlocução entre os estudos e exames jurídico, psiquiátrico, psicológico e social. Como mostra da abordagem interdisciplinar, pode-se citar que "o exame criminológico se vale da experiência clínica em entrevista psiquiátrica e dos critérios da Psiquiatria para a compreensão de um quadro psíquico. Vale-se, também, da tradição da Psicologia, nas entrevistas de diagnóstico, além das tradicionais e já cientificamente embasadas técnicas de exame de personalidade e de inteligência. Vale-se, também, de toda a experiência

\footnotetext{
${ }^{173}$ Arthur Bragança de Vasconcellos Weintraub e Josue Modesto Passos, O direito de execução penal brasileiro: uma analise a luz do pensamento criminológico, Revista Brasileira de Ciências Criminais. n.23, p. 167.

${ }_{174}$ CEZAR ROBERTo BITTENCOURT, Regimes penais... cit. p.266.

${ }^{175}$ ALVINO AUGUSTO DE SÁ, Os três instrumentos de avaliação dos apenados na legislação penal brasileira, Justiça e Democracia n.3, 1997, p.164.

${ }^{176}$ ALVINo Augusto De SÁ, Equipe criminológica: convergências e divergências, Revista IBCCrim n², 1993, p 41.
} 
historicamente colhida e validada dos profissionais de Serviço Social, na análise e compreensão do indivíduo em seu histórico familiar e social. A esses exames, soma-se o estudo jurídico do caso, com o devido detalhamento do histórico do examinando em suas práticas tidas como criminosas, suas penas, sua vida prisional, etc., tudo isso servindo de "matéria prima" a ser levada em conta no exame. Na interlocução de todos esses estudos e dados, a equipe discute-os e busca compreender (não explicar) como a assim chamada conduta criminosa (ou seja, a conduta socialmente problemática) se insere em todo o complexo contexto pessoal do examinando". ${ }^{177}$

\subsection{Tipos de exame criminológico}

Existem duas modalidades de exame criminológico: o exame criminológico de entrada, cuja finalidade é fornecer subsídios de classificação dos presos, e o exame criminológico feito para fins de instrução de pedidos de benefícios legais.

De acordo com a redação original da Lei 7.210/84, Lei de Execução Penal, o exame criminológico seria realizado em dois momentos na execução penal: (i) quando da inclusão do sentenciado na penitenciária, a fim de individualizar a sua execução, nos termos do artigo $8^{\circ}$ da LEP e (ii) quando da análise dos pedidos de progressão de regime prisional, livramento condicional, indulto e comutação de penas durante a execução da pena, de acordo com o artigo 112, parágrafo único, da LEP, parágrafo este que foi revogado pela Lei $10.792 / 03$, sendo substituído pelos $\S \S 1^{\circ}$ e $2^{\circ}$ que nada dispõem sobre o exame criminológico, com o escopo de diagnosticar a aptidão do apenado para o retorno ao meio social e possibilitar uma aferição sobre possíveis desdobramentos futuros de sua conduta, em termos de probabilidade de recidiva.

\subsubsection{De entrada}

A individualização da pena pode ser vista sob três ângulos: (i) a individualização legislativa, (ii) individualização judicial e (iii) individualização executória.

${ }^{177}$ ALVINO Augusto DE SÁ, O exame criminológico e seus elementos essenciais, Boletim IBCCrim $\mathrm{n}^{\mathrm{o}} 214$, set.2010, p.4. 
A individualização da pena é um dos princípios norteadores do Direito da Execução Penal, e consiste na ideia de que a execução da pena não pode consistir no fato do apenado executar dia-a-dia as mesmas tarefas e, também que a execução penal não pode ser idêntica para todos os sentenciados.

Individualizar, na execução penal, significa dar a cada preso as melhores condições para o cumprimento da sanção imposta; é conceder-lhe oportunidade e elementos necessários e suficientes para conseguir sua reinserção social. A individualização, modernamente, deve ocorrer técnica e cientificamente. ${ }^{178}$

Visando a individualização da pena, o artigo $8^{\circ}$, da LEP determina a obrigatoriedade da realização de exame criminológico para o condenado que for iniciar o cumprimento em regime fechado e faculta a sua realização quando o regime inicial for o semiaberto.

Na mesma esteira, o Código Penal em seu artigo 34 preceitua que o condenado será submetido, no início do cumprimento da pena, ao exame criminológico de classificação para individualização da execução.

Desse modo, a primeira tarefa a desempenhar para individualizar a pena é conhecer aquele com relação ao qual deve ser formulado o programa individualizador. Para tanto em primeiro lugar a LEP prevê a realização do exame criminológico. ${ }^{179}$

Quando do ingresso no sistema carcerário, o exame criminológico tem como finalidade fornecer elementos que auxiliem na classificação dos apenados para uma individualização executória.

É muito importante realizar o exame criminológico no início de cumprimento de pena, pois, teoricamente, o condenado ainda não se contaminou dos efeitos perniciosos da vida carcerária, encontra-se temporalmente mais próximo de sua atividade criminosa, com o que o diagnóstico criminológico tende a ser mais fidedigno, mais confiável, enquanto perícia. $^{180}$

Se o sentenciado for submetido ao exame criminológico logo no início do cumprimento de pena, o resultado desse primeiro laudo poderá ser comparado com os exames que serão realizados ao longo da execução da pena e assim ajudar a constatar se a

\footnotetext{
${ }^{178}$ CEZAR ROBERTO BITTENCOURT, Regimes penais... cit., p.269.

${ }^{179}$ Arthur Bragança de VAsconcellos Weintraub e Josue Modesto Passos, O direito de execução ... cit., p. 167.

${ }^{180}$ Alvino Augusto de SÁ, Os três instrumentos ... cit., p.165.
} 
terapêutica penal está gerando bons resultados ou se a triste realidade do cárcere afetou, ou melhor, prejudicou ainda mais o apenado.

Com submissão do condenado ao exame de classificação e ao exame criminológico de entrada inicia-se a colheita de provas na execução penal, provas essas, "de interesse não só para a administração penitenciária no trato diário com o preso, mas também para o Juízo, visto que tais exames nortearão o desenvolvimento dos regimes e demais ocorrências prisionais. São esses exames, portanto, integrantes da instrução das decisões judiciais subsequentes e elementos importantes de prova, na decisão de incidentes de execução.". ${ }^{181}$

A classificação serve como marco para a execução da pena, porque somente tendo o conhecimento de como era o condenado no tempo do ingresso no sistema carcerário é que se poderá saber, futuramente, ao longo do cumprimento da pena, se o presidiário evoluiu, isto é, se está apto para retornar ao convívio social por meio da progressão ou livramento condicional, ou não, devendo permanecer mais tempo no regime em que se encontra.

Insta consignar que o exame criminológico não deve ser confundido com o exame de classificação, também conhecido como exame de personalidade, previsto nos artigos $5^{\circ}$ e $6^{\circ}$ da LEP. A diferença entre o exame de personalidade e o exame criminológico é sutil, o que pode gerar uma confusão conceitual, admitindo-se os exames como sinônimos. Enquanto o exame criminológico estuda o sujeito enquanto criminoso e procura explicar os motivos pelos quais ele cometeu o delito, o exame de personalidade estuda o sujeito enquanto pessoa. Assim, se interessa por sua história enquanto indivíduo, não enquanto infrator legal.

O exame de classificação visa obter dados do agente além do crime cometido, pela análise de sua personalidade, conforme Exposição de Motivos item 34, e o exame criminológico refere-se ao diagnóstico e prognóstico criminológico e aspira, partindo-se do binômio delito-delinquente, ao entendimento das causas do delito e da motivação do agente. $^{182}$

Nos termos da Lei de Execução Penal, depois de confeccionado pelo Centro de Observação, o laudo criminológico será encaminhado à Comissão Técnica de Classificação, que elaborará o exame de personalidade, utilizando-se, entre outros elementos, do exame criminológico. Com as informações obtidas por meio do exame

\footnotetext{
${ }^{181}$ SiDNEI AGOSTINHO BENETI, Execução penal... cit., p.133.

${ }^{182}$ CARMEN Silvia DE MORAES BARROS, As modificações... cit., p. 190.
} 
criminológico e do exame de personalidade, a Comissão Técnica de Classificação deverá proceder à elaboração de um programa individualizador.

No sistema ideal, projetado pelo legislador, formulado o programa individualizador e classificado o sentenciado prosseguirá finalmente a execução penal os seus termos, com a aplicação das atividades e serviços necessários e a assistência da comunidade, a fim de que paulatinamente o condenado melhore a compreensão que tem de si, da sua conduta pregressa, das perspectivas que se lhe podem abrir, dos valores aos quais deverá atribuir maior importância, etc. ${ }^{183}$

\subsubsection{Para benefícios ${ }^{184}$}

Uma das diretrizes da execução da pena é o sistema progressivo de cumprimento de pena que consiste na ideia de o condenado ir (re)conquistando paulatinamente sua liberdade e assim garantir mais êxito na reinserção social.

No sistema progressivo evolui-se do regime mais rigoroso para outro menos rigoroso. Para tanto é necessário que o encarcerado cumpra determinado lapso temporal instituído em lei em regime anterior mais gravoso para passar para o posterior mais brando. Todavia não basta somente o resgate do lapso temporal, é indispensável que o sentenciado demonstre que merece a progressão e que está preparado para cumprir a pena em regime mais ameno, sem comprometer a finalidade da pena e colocar em risco a sociedade.

Com a finalidade de evitar a incompatibilidade do apenado com o novo regime, e consequentes prejuízos à defesa social e aos fins da pena, instituiu-se a realização do exame criminológico para aferir o mérito do sentenciado e assim ajudar a balizar a decisão judicial a ser dada nos incidentes de execução, em especial nos de progressão de regime e livramento condicional.

A ideia de prognóstico comportamental como medida para atribuição de castigos, ou privilégios no âmbito penal, amparando-se em um juízo de periculosidade e na subsunção ao saber médico ${ }^{185}$, fortalece-se com o nascimento da criminologia, ante a

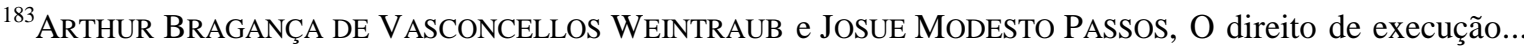
cit, p. 169.

${ }^{184}$ Importante registrar que se utiliza a palavra "benefício" para se referir à progressão de regime, livramento condicional, comutação e indulto, por ser o termo de praxe encontrado na doutrina e na jurisprudência, e não com o sentido de ser a concessão de tais institutos um privilégio ao condenado. Ao contrário, no processo de execução penal, tais institutos são direitos subjetivos do condenado desde que preenchidos os requisitos legais para sua obtenção.

${ }^{185}$ ALESSANDRA TEIXEIRA. Do sujeito... cit., p. 25.
} 
influência da ciência jurídica por outras ciências, como antropologia, psicologia, medicina social e psiquiatria.

Consoante exposição de Alessandra Teixeira acerca da organização dos sistemas penais, o surgimento do "sistema progressivo inglês ou irlandês ${ }^{186}$, através do qual o condenado cumpriria pena em fases ou regimes, progredindo aos mesmos segundo o tempo decorrido e especialmente, por seu comprovado mérito" coincide com o apogeu da escola criminológica positiva, para a qual a pena de prisão encontraria suas finalidades a partir da lógica corretiva e transformadora que o cárcere promoveria, em oposição à orientação retributiva clássica e liberal. ${ }^{187}$

O exame criminológico destinado à instrução de pedidos de benefícios abrange uma combinação entre estudos e exames jurídico, psiquiátrico, psicológico e social objetivando uma conclusão sobre a conveniência ou não de concessão do benefício, tudo dentro de uma abordagem interdisciplinar. ${ }^{188}$

Com a previsão deste tipo de exame criminológico, a progressividade da pena está alicerçada na noção de merecimento o qual deverá ser constatado por critérios não exclusivamente definidos pela administração carcerária, mas também por uma avaliação científica.

Destarte, no que tange a forma progressiva de cumprimento da pena, na redação originária da Lei de Execução Penal, dispunha o artigo 112, parágrafo único, que a decisão será motivada e precedida de parecer da Comissão Técnica e do exame criminológico, quando necessário.

Da atenta análise da redação do dispositivo, e partindo da ideia que não existem palavras inúteis na lei, extrai-se que o parecer da Comissão Técnica e o exame criminológico são coisas distintas, pois caso fossem sinônimos a legislação não teria

\footnotetext{
${ }^{186}$ MANOEL PEDRo PIMENTEl elucida que o sistema progressivo surgiu na Inglaterra, no século XIX. A característica do sistema progressivo inglês era a adoção do critério de dividir o tempo de cumprimento da pena em três períodos: o primeiro era chamado o período de prova, com isolamento celular completo de tipo pensilvânico; o segundo período iniciava-se com a permissão dada ao preso para trabalhar na comunidade carcerária, observando, porém, a regra auburniana do rigoroso silêncio e mantendo-se em isolamento noturno, passando, depois de algum tempo, para as chamadas public work-houses, com vantagens maiores; finalmente, o terceiro período, no qual, pela correção demonstrada, o prisioneiro obtinha o ticket of leave, ou seja, o benefício da liberdade condicional. Com ligeiras diferenças, o sistema progressivo irlandês compreendia quatro etapas ou períodos: o penal, na cela; o da reforma, pelo isolamento noturno; o intermediário, com trabalho em comum, caracterizado pelo fato dos prisioneiros vestirem roupas civis e desempenharem externos, como verdadeiros trabalhadores livres; o da liberdade provisória, que se tornava definitiva pelo bom comportamento. O acesso a cada uma dessas etapas era feito progressivamente, através do ganho de vales merecidos. (Sistemas penitenciários... cit., p.268)

187 Alessandra TeIXEIRA. Do sujeito... cit., p.26.

${ }^{188}$ ALVINO AUGUSTO DE SÁ, O exame criminológico... cit.,p.04.
} 
utilizado a conjunção "e". Todavia, na prática, o exame criminológico é substituído por pareceres emitidos pela Comissão Técnica de Classificação, sendo importante efetuar a distinção conceitual entre os institutos.

Na prática, ao introduzir o parecer da Comissão Técnica e o exame criminológico na sistemática da progressão de regime, o legislador promoveu um deslocamento de poderes no interior da prisão, permitindo que o merecimento do condenado fosse avaliado por pessoas alheias aos agentes de segurança do quadro administrativo do estabelecimento penal em que o avaliado cumpria pena. Buscava-se uma maior precisão científica sobre a conveniência ou não de concessão do benefício ao apenado avaliado, e ao mesmo tempo evitava-se arbitrariedade na avaliação feita pelos agentes administrativos.

Hoje, o parágrafo único, do artigo 112, da Lei de Execução Penal foi substituído pelos $\S \S 1^{\circ}$ e $2^{\circ}$, nos temos da Lei $n^{\circ} 10.792 / 03$. A nova redação dada ao dispositivo pela mencionada lei estipula que a decisão será motivada, precedida de manifestação do Ministério Público e da defesa $\left(\S 1^{\circ}\right)$, com igual procedimento para a concessão de livramento condicional, indulto e comutação de penas $\left(\S 2^{\circ}\right)$.

A alteração introduzida pela Lei $n^{\circ} 10.792 / 03$ ao artigo 112, da LEP, materializa a obrigação de abertura de vista as partes antes de se proferir a decisão judicial nos incidentes de execução, consolidando o respeito ao princípio do contraditório no processo de execução penal, fortalecendo a jurisdicionalização nesta fase.

Por outro lado, com o advento da Lei n ${ }^{\circ}$ 10.792/03, instaurou-se acirrada discussão na doutrina e na jurisprudência a respeito da admissibilidade, ou não do exame criminológico por ocasião de pedido de benefícios legais.

\subsection{Estrutura}

O exame criminológico deverá ser realizado no Centro de Observação, nos termos do artigo 95, da Lei de Execução Penal. Contudo, a lei foi omissa quanto aos profissionais que participariam deste Centro, não sendo explicitadas as áreas técnicas que compõem a equipe da perícia criminológica. Tal fato reflete diretamente na estrutura do exame criminológico, pois não se sabe ao certo quais peças deveriam compor esta perícia.

Como a própria legislação previu que na falta do Centro de Observação, o exame poderá ser realizado pela Comissão Técnica de Classificação (CTC), por equiparação, admite-se que o exame criminológico seja instruído por peças confeccionadas pelas 
mesmas categorias profissionais componentes da CTC (chefes de serviço, psiquiatra, psicólogo e assistente social).

Vale lembrar que o exame criminológico é uma perícia, e como tal tem que ser elaborado por peritos, pessoas com conhecimento técnico-científico pertinente a questão a ser examinada, porém, a Comissão Técnica de Classificação não é composta exclusivamente por técnicos. Dos componentes da CTC, os únicos que não são dotados de conhecimentos especializados nos moldes compatíveis com noção de perícia são os chefes de serviço, agentes administrativos, que certamente contribuiriam relatando os fatos que envolvem o cotidiano do apenado sob o ângulo da convivência e disciplina, sem desenvolver um juízo crítico sobre o que foi observado. Desse modo, dispensa-se o comentário desses agentes, sendo aceito o exame criminológico formado basicamente pelos pareceres psiquiátricos, psicológicos e sociais.

Ademais, de acordo com a Exposição de Motivos da Lei de Execução Penal o exame criminológico propõe-se à investigação médica, psicológica e social do recluso, o que corrobora o entendimento pela dispensabilidade dos comentários do chefe de serviço para formar o exame criminológico.

Quando o legislador idealizou o exame criminológico determinou que ele fosse elaborado pelo Centro de Observação, o qual deveria ser instalado em unidade autônoma ou em anexo da unidade prisional, assim, os técnicos responsáveis por sua confecção não teriam um contato cotidiano com o preso. Esta disposição se justifica para assegurar a imparcialidade na produção do laudo, evitando conclusões viciadas ou induzidas, e vai ao encontro da opinião de especialistas que concordam ser indispensável que os exames interdisciplinares que constituem o exame criminológico sejam aplicados e avaliados por técnicos que não acompanhem ou mantenham contato com o reeducando durante o período de execução da pena. ${ }^{189}$

O exame criminológico deve reunir algumas características: terá que ser completo, contendo todos os antecedentes de valor; fidedigno, constatando o perito, com exatidão, cada um dos antecedentes proporcionados pelo acusado e pelos outros interrogados; pertinente ao caso em estudo, com a máxima objetividade, evitadas as generalizações; breve, tão sintético, preciso e conciso, como seja possível, evitando-se toda e qualquer erudição; inteligível, ou seja, redigido em linguagem compreensível e direta, utilizando-se um mínimo de expressões técnicas de maneira que até os leigos na matéria sejam capazes

\footnotetext{
${ }^{189}$ NOELI KÜHL SVOBODA BESSA, Os instrumentos técnicos... cit, p.211.
} 
de entender os seus resultados; e rápido, posto à disposição dos órgãos judiciais em tempo breve, de modo a não contribuir indevidamente ao prolongamento do processo. ${ }^{190}$

Não raro, os laudos são diferentes uns dos outros, principalmente quando confeccionados em Comarcas distintas. Dessa forma, determinado exame criminológico atenta para uma questão que em outro sequer é ventilada, revelando ausência de método.

A falta de metodologia compromete a cientificidade da prova, transformando o exame criminológico em mero relato de entrevista do que propriamente em um estudo. Os exames se converteram numa reprodução, na transcrição das palavras do sentenciado sem qualquer análise mais apurada por parte dos peritos.

Não se pode deixar de considerar, contudo, que os peritos ficam a mercê daquilo que é relatado pelo sentenciado, uma vez que não lhes é dado subsídios para aprimorarem sua pesquisa a fim de melhor elaborar os exames. O exame de classificação, por exemplo, raramente é feito, o que dificulta constatar se houve uma evolução do condenado ao longo de sua pena por ausência completa de parâmetros. Raramente existe no prontuário do apenado uma pesquisa profunda acerca de sua vida e personalidade. Enfim, inexiste acompanhamento de qualquer ordem.

Em dissertação de mestrado defendida perante a Faculdade de Direito da Universidade de São Paulo na década de 70, ou seja, datada de muito antes da edição da Lei $n^{\circ} 7.210 / 84$, encontram-se registros de que sempre foi difícil a elaboração dos laudos, anotando-se que a "experiência revela que os peritos somente conseguem obter informes sobre a pessoa e a família do réu, desde que possam contar com a boa vontade e espírito de cooperação do próprio acusado, - tal a precariedade do instrumental investigatório colocado à sua disposição". 191

A prova pericial justamente por ser dotada de cientificidade deve observar um método que permita com que os laudos guardem o mínimo de unidade e padronização. Há que se buscar a convergência na estrutura dos laudos a fim de possibilitar a existência de um parâmetro que afira quando o laudo é lacônico e regular, e quando é completo e bom.

Os exames criminológicos deveriam apresentar uma padronização não só com relação ao método, mas também no aspecto formal, o que permitiria a comparação entre os laudos e auxiliaria aquele que os analisa, no caso o magistrado, saber se todos os pontos foram abordados, se o laudo foi exaustivo, etc..

\footnotetext{
${ }^{190}$ VILSON FARIAS, O exame criminológico na aplicação da pena, Revista Brasileira de Ciências Criminais. São Paulo v.4.n15,jul./set. 1996, p.290.

${ }^{191}$ DJALMA LÚCIO GABRIEL BARRETO, Instituição do exame criminológico e suas implicações processuais. Dissertação de mestrado. Faculdade de Direito da USP, São Paulo, 1976, p.7.
} 
A questão da linguagem também deve ser considerada, afinal, para que a prova pericial possa cumprir corretamente sua função, devem os juízes, bem como as partes, compreender a linguagem utilizada pelo perito, que é sua ferramenta lógica. Em sua maciça maioria, os laudos contêm termos que, inclusive por seu caráter de generalidade e pouca precisão, dão margens a múltiplas interpretações ${ }^{192}$, o que compromete ainda mais a formação da convicção judicial respaldada em elementos sólidos.

Na prática, verifica-se que os laudos não obedecem a uma forma de apresentação e elaboração, o que prejudica os parâmetros para análise do magistrado. Somente com a vivência e experiência é que um magistrado vai saber se o exame criminológico com o qual está tendo contato é bom ou ruim, levando em consideração todos os outros que já leu em sua carreira. Temerário tal fato. Basta imaginar um juiz iniciante na Vara das Execuções Criminais que defira benefícios, pois considera os laudos criminológicos elaborados satisfatórios. Contudo, com o passar dos anos, vai tendo contato com outros laudos e verifica que aqueles laudos do início de sua carreira não eram tão bons assim quando comparados com os laudos supervenientes, e, então se depara novamente com o laudo de mesma estrutura e, quiçá, elaborado pelos mesmos peritos daquele do início da sua carreira, mas, agora, indefere o benefício. Ora, o laudo de mesma estrutura serviu para o deferimento e para o indeferimento de beneficio. Evidente, o prejuízo ao jurisdicionado.

O professor Alvino Augusto de Sá há muito já apontava que os exames criminológicos divergiam quanto à estrutura, ao plano e às peças que os compunham, chegando a sugerir uma estrutura que, do seu ponto de vista, mais atenderia às necessidades do exame, qual seja: Finalidade do exame; Estudo jurídico-penal; Informações carcerárias e terapêutico-penais; Avaliação social; Avaliação psicológica; Avaliação psiquiátrica; Discussão; Conclusão. ${ }^{193}$

\subsection{Objetivo $^{194}$}

Instituído com a finalidade de orientar cientificamente o cumprimento da pena, o exame criminológico tem como objetivo "a investigação médica, psicológica e social", nos termos da Exposição de Motivos da Lei de Execução Penal.

\footnotetext{
${ }^{192}$ Alvino AuguSTO DE SÁ, Equipe criminológica... cit., p. 44

193 Idem, p 42-43.

${ }^{194} \mathrm{O}$ objeto de estudo do presente trabalho é o exame criminológico feito para fins de instrução de pedidos de benefícios legais, assim, este tópico será focado nesta modalidade.
} 
Trata-se de exame pericial, cuja função seria a análise bio-psico-social do sentenciado, para o início do cumprimento de pena, visando a investigação dinâmica do ato criminoso, de suas causas e dos fatores a eles associados, oferecendo em primeiro lugar um diagnóstico criminológico e, como segunda vertente, um prognóstico criminológico do delinquente (conclusão pela maior ou menor probabilidade de reincidência) e que, segundo a prática rotineira nos sistemas penitenciários do Estado de São Paulo, compõe-se dos estudos jurídico, social, psicológico, psiquiátrico, nos termos em que é proposto pela Lei de Execução Penal, que deve ser realizado para a obtenção dos elementos necessários a uma adequada classificação e com visitas à individualização da execução. ${ }^{195}$

Analisa o binômio delito-delinquente, objetivando desvendar a motivação criminal, a dinâmica criminal, isto é, o conjunto de fatores que permitem descobrir a origem e desenvolvimento da conduta criminal do examinando.

Quando destinado a instruir incidentes de execução, o exame criminológico objetiva "descobrir a capacidade de adaptação do condenado ao regime de cumprimento de pena; a probabilidade de não delinquir; o grau de probabilidade de reinserção na sociedade, através de um exame genético, antropológico, social e psicológico". ${ }^{196} \mathrm{Na}$ definição de Renato Marcão o exame criminológico é realizado para o resguardo da defesa social, e busca aferir o estado de temibilidade do delinquente. ${ }^{197}$

\section{Diferenças entre o exame criminológico e os exames elaborados pela Comissão Técnica de Classificação}

São três os instrumentos de avaliação do condenado previstos pela Lei de Execução Penal: o exame de classificação ou de personalidade, o exame criminológico e o parecer da Comissão Técnica de Classificação (CTC).

Existe uma confusão entre os termos exame criminológico, exame de classificação ou de personalidade e parecer da CTC, os quais são tratados como se expressões equivalentes fossem, todavia, são institutos distintos que não podem ser confundidos entre si, sendo de extrema relevância efetuar a distinção conceitual entre eles.

\footnotetext{
${ }^{195}$ PAUlo Sergio XAVIER DE SoUZA, A vinculação do juiz ao exame criminológico, Justiça e Sociedade. Revista Jurídica da FCJAC-UNOESTE v.1.n.2, dez. 1999, p.275.

${ }^{196}$ CEZAR Roberto BITTENCOURT, Regimes penais... cit, p.267.

${ }^{197}$ RENATO FLÁVIO MARCÃo, Curso de execução penal, $8^{\mathrm{a}}$ ed., São Paulo:Saraiva, 2010, p.44.
} 
Incumbe à Comissão Técnica de Classificação a elaboração de um programa individualizador com indicações do tratamento penal a ser desenvolvido na unidade prisional, e, de conhecimento desse plano, propor a formação de expedientes de progressão de regime e livramento condicional. São elaborados por esta Comissão o exame de personalidade, também conhecido como exame de classificação, feito quando do ingresso do sentenciado na unidade prisional, e pareceres ao longo de toda a execução penal.

Por seu turno, o exame criminológico deve ser elaborado pelo Centro de Observação Criminológica (COC) e procura analisar a relação causa e efeito, ou seja, o que levou aquela pessoa a delinquir.

Enquanto a Comissão Técnica de Classificação atua no próprio local da execução, o Centro de Observação Criminológico é estabelecido em local autônomo da unidade carcerária e realiza exames periciais e pesquisas criminológicas que retratarão o "perfil do preso", fornecendo auxílio nas decisões judiciais dos incidentes da execução. ${ }^{198}$

Há omissão legal quanto à composição do pessoal especializado do Centro de Observação Criminológico, já a composição da Comissão Técnica de Classificação encontra-se definida no artigo $7^{\circ}$ da LEP.

Conforme previsão legal, a Comissão Técnica de Classificação será presidida pelo diretor e composta, no mínimo, por 2 (dois) chefes de serviço, 1 (um) psiquiatra, 1 (um) psicólogo e 1 (um) assistente social. No entanto, nada impede que a Comissão Técnica de Classificação possuía outros componentes, sendo os referidos no artigo $7^{\circ}$ da Lei de Execução Penal apenas seus integrantes básicos. Além desses, a CTC pode ser composta dos mais diversos profissionais de diferentes áreas relacionadas com a reabilitação da pessoa encarcerada (Médico, Psiquiatra, Psicólogo, Assistente Social, Artistas Plásticos, Terapeuta Ocupacional, Agentes Penitenciários, Musicoterapeuta) tudo depende de quais profissionais serão disponibilizados pelo Sistema Penitenciário para assistir aos presos ${ }^{199}$. Quando mais plural for a equipe da CTC melhores são as perspectivas de se chegar a uma avaliação mais completa e abrangente do preso.

O ponto em comum entre a CTC e o COC é que ambos desenvolvem trabalho que visa possibilitar aos técnicos propor ou opinar às autoridades competentes sobre a viabilidade das progressões e regressões de regime, conversões de penas, livramento condicional, etc..

\footnotetext{
${ }^{198}$ SAlo de CARVAlHo, O papel da perícia psicológica na execução penal. Psicologia Jurídica no Brasil, $2^{\mathrm{a}}$ ed., Rio de Janeiro: Nau, 2005, p.142.

${ }^{199}$ NOELI KÜHL SVOBODA BeSSA, Os instrumentos técnicos... cit., p.216.
} 
Com relação ao COC, em sua obra, Guilherme de Souza Nucci comenta que lamentavelmente, sob o argumento vetusto da falta de recursos, vários Estados estão abandonando esses Centros, interrompendo suas atividades e desativando-os. ${ }^{200}$

Em São Paulo, o Centro de Observação Criminológico, anexo à Penitenciária, foi extinto $^{201}$ pelo Decreto $n^{\circ} 46.483$, de 02 de janeiro de 2002, passando a realização do exame criminológico a ser atribuição do Núcleo de Observação Criminológica, órgão da Secretaria de Administração Penitenciária. Posteriormente, pelo Decreto $n^{\circ}$ 54.235, de 14 de abril de 2009, o Núcleo de Observação Criminológica foi transferido, com seus cargos e funções-atividades, acervo, direitos e obrigações, para o Hospital de Custódia e Tratamento Psiquiátrico "Prof. André Teixeira Lima” de Franco da Rocha.

Essa regulamentação da administração penitenciária revela a intenção estatal de desmanchar o aparato institucional existente para o acompanhamento e avaliação dos presos, e, na verdade, representa um desdobramento da mudança na política carcerária com vistas a suprimir a previsão legal de realização de laudos ou exames criminológicos lastreada na Lei $\mathrm{n}^{\circ} 10.792 / 03$.

Na falta do Centro de Observação Criminológico, o artigo 98 da LEP admite que os exames sejam feitos pela Comissão Técnica de Classificação.

Atribuir a CTC a confecção do exame criminológico é muito criticado, pois este exame, justamente por ter natureza pericial, deveria ser elaborado por técnicos que não acompanhem ou mantenham qualquer contato com o reeducando durante o período de execução da pena. A CTC é integrada por profissionais que acompanham o dia-a-dia do preso, ou deveriam acompanhar, pois esta é uma de suas funções definidas em lei, "pelo que, eticamente, estariam impedidos de fazer perícia nesse preso, já que nenhum profissional deveria ser perito de alguém em cujo processo de recuperação encontra-se engajado". 202

Considerando a insuficiência de Centro de Observação Criminológico implantados no país, a maioria dos exames criminológicos é elaborada pela Comissão Técnica de

\footnotetext{
${ }^{200}$ GUILHERME DE SOUZA NUCCI, Leis penais... cit., p.484.

${ }^{201}$ Nesse sentido, ALESSANDRA TEIXEIRA comenta que "a extinção, à primeira vista inesperada, do COC, foi interpretada à época pelos operadores da área apenas como mais uma medida de readequação administrativa e ainda sintomática das deficiências e precariedades na estruturação dos serviços oferecidos pela SAP, tendo representado também, segundo alguns, um "retrocesso", mas não como o prenúncio de uma ruptura ou de um deslocamento com relação aos eixos que haviam sido definidores da LEP e, enfim, da política penitenciária adotada a partir de 1984.", referindo-se à superveniência da Lei 10.792/03 e à jurisdicionalidade da execução penal. (Do sujeito ... cit., p.158.)

${ }^{202}$ Alvino AUguSTO DE SÁ, Criminologia Clínica e psicologia criminal, São Paulo: RT, 2007, p.196.
} 
Classificação, passando-se a denominar, erroneamente, qualquer parecer elaborado pela CTC como sendo o exame criminológico.

Atento a este cenário, Nucci comenta que o exame de classificação, o exame criminológico e o parecer da Comissão Técnica de Classificação não diferem, na prática, constituindo uma única peça, feita por vezes, pelos mesmos profissionais em exercício no estabelecimento penal. ${ }^{203}$

É lamentável, que os três institutos (exame criminológico, exame de personalidade e parecer da CTC) sejam, na prática, tratados como se sinônimos fossem e sintetizados na mesma avaliação, pois a interação entre eles é de enorme importância para o aprimoramento da individualização da execução orientada por critérios científicos e técnicos.

\subsection{Exame de personalidade.}

O exame de personalidade, também conhecido como de classificação, consiste em uma pesquisa, um inquérito sobre o agente para além do crime cometido ${ }^{204}$, cujo objetivo principal é estudar a personalidade do reeducando focando seu potencial humano, interesses e vocação, visando a sua recuperação, ou seja, encontrar os elementos que sejam capazes de promover sua ressocialização, bem como promover, organizar e implementar o programa de individualização da pena nas unidades penais. ${ }^{205}$

Ao contrário do exame criminológico, o exame de personalidade é elaborado pela equipe técnica interdisciplinar da Comissão Técnica de Classificação, afinal pressupõe um acompanhamento e avaliação da pessoa do reeducando e não apenas do ilícito praticado.

Nas palavras de Nucci, a diferença entre o exame de classificação e o exame criminológico é a seguinte: o primeiro é mais amplo e genérico, envolvendo aspectos relacionados à personalidade do condenado, seus antecedentes, sua vida familiar e social, sua capacidade laborativa, entre outros fatores, aptos a evidenciar o modo pelo qual deve cumprir sua pena no estabelecimento penitenciário (regime fechado ou semiaberto); o segundo é mais específico, abrangendo a parte psicológica e psiquiátrica do exame de classificação, pois concede maior atenção à maturidade do condenado, sua disciplina, capacidade de suportar frustrações e estabelecer laços afetivos com a família ou terceiros,

\footnotetext{
${ }^{203}$ GuILHERMe De SouZa NuCCI, Manual de Processo... cit., p.951.

${ }^{204}$ NoELI KÜHL SVOBODA BESSA, Os instrumentos técnicos... cit., p.210.

${ }^{205}$ Idem, p. 213.
} 
grau de agressividade, visando à composição de um conjunto de fatores, destinados a construir um prognóstico de periculosidade, isto é, sua tendência a voltar à vida criminosa. $^{206}$

Alvino Augusto de Sá sintetiza as diferenças entre esses dois exames ao esclarecer que o exame criminológico enfoca o binômio delito-delinquente, busca investigar as causas do comportamento criminoso, ou seja, volta-se para a dimensão antissocial da conduta do apenado, procurando "explicá-la" e, com isso, inferir sobre a probabilidade de reincidência. Já por isso mesmo, ele se chama criminológico. O exame de personalidade não se volta para o "lado criminoso" do condenado, para a investigação das "causas" de sua conduta criminosa, mas, sim, para sua pessoa, na sua realidade integral e individual, incluída aí toda sua história, história de uma pessoa, e não mais de um criminoso. ${ }^{207} \mathrm{E}$ arremata que a diferença fundamental entre os dois exames é que o exame criminológico é perícia, mas o de personalidade não é perícia; é, sim, antes de tudo, um exame clínico.

O exame criminológico auxilia o magistrado na tomada de decisão jurídica procurando fornecer-lhe elementos esclarecedores sobre determinado fato juridicamente relevante. Por seu turno, o exame de personalidade não visa oferecer elementos de prova, mas somente analisar a personalidade do apenado, enquanto indivíduo.

\subsection{Pareceres da Comissão Técnica de Classificação}

Com relação aos pareceres da Comissão Técnica de Classificação, Noeli Kühl Svoboda Bessa, ressalta que eles devem ser compreendidos sob duas perspectivas: o parecer pode ser elaborado enquanto parte integrante de uma sequencia de laudos periódicos que versam sobre a avaliação do desempenho global e evolução da pessoa encarcerada em momentos distintos da execução da pena, ou pode ser formulado enquanto um laudo conclusivo, confeccionado por ocasião do preenchimento do requisito objetivo do cumprimento da pena visando a progressão de regime. ${ }^{208}$ É essa segunda modalidade que interessa para o desenvolvimento do presente trabalho.

O parecer resulta de observações obtidas através do acompanhamento do cotidiano do apenado, portanto, sua elaboração é mais lenta, considerando que as avaliações devem ser sucessivas e periódicas.

\footnotetext{
${ }^{206}$ GuIlHerme DE SoUZA NuCCI, Manual de Processo ... cit., p.951.

${ }^{207}$ Alvino Augusto dE SÁ, Os três instrumentos... cit., p.166.

${ }^{208}$ NOELI KÜHL SVOBODA BESSA, Os instrumentos técnicos... cit., p.214.
} 
Nessa esteira os pareceres são elaborados ao longo do tempo, em um plano ideal, com acompanhamento diário, colhendo-se dados e organizando os informes na busca de avaliar a qualidade da resposta do preso à terapêutica penal. Não se trata de uma avaliação pontual, mas reflete toda uma história, uma história de vida prisional, em face das propostas, facilidades, oportunidades, limites e obstáculos da instituição, em contraponto com a história da vida pregressa do preso. ${ }^{209}$

Desse modo, o objetivo principal desses pareceres repousa na avaliação dos níveis da qualidade adaptativa da conduta da pessoa encarcerada a nível consciente, bem como sua capacidade de crítica e de gerenciamento de sua conduta. ${ }^{210}$

Compete à Comissão Técnica de Classificação propor à autoridade competente, progressão e regressão de regime, bem como as conversões. Estas sugestões são materializadas por meio de pareceres. Deve-se esclarecer, no entanto, que há quem sustente que os pareceres da Comissão Técnica de Classificação enquanto proposta feita pela autoridade competente para progressões de regime foi lamentavelmente extinto por força da Lei 10.792/2003. ${ }^{211}$

A legislação autoriza que a Comissão Técnica de Classificação elabore, em caráter supletivo, na ausência de Centro de Observação Criminológico, o exame criminológico, cujo objeto é a relação causa e efeito do crime, porém, nem tudo que a CTC confecciona deve receber a denominação de exame criminológico.

$\mathrm{Na}$ realidade, em se tratando de pedido de progressão prisional, o Exame Criminológico vem sendo dispensado, bastando apenas o parecer da Comissão Técnica de Classificação, utilizado como regra geral para as decisões dos magistrados, principalmente nas comarcas do interior, onde é impossível a realização do exame criminológico, que só é feito no Centro de Observação (art. 96 da LEP) existente na Capital. ${ }^{212213}$

Embora, na prática, o exame criminológico seja substituído por pareceres emitidos pela Comissão Técnica de Classificação, de rigor delimitar e diferenciar os institutos, para o adequado tratamento da matéria, evitando-se o emprego errôneo de certas expressões e o consequente fomento a equívocos e contradições.

\footnotetext{
209 Alvino Augusto de SÁ, Criminologia Clínica ... cit., p.199.

${ }^{210}$ NoEli KÜHL SvOBODA BeSSA, Os instrumentos técnicos ... cit., p.215.

211 Alvino Augusto de SÁ, Criminologia Clínica ... cit., p.198.

${ }^{212}$ Refere-se aqui ao Estado de São Paulo, cujo único Centro de Observação Criminológica (COC) localizava-se na Capital, o qual foi desativado pelo Decreto ${ }^{\circ} 46.483$ de 2002, em razão da política de desmonte do aparato institucional criminológico que redundaria na Lei $n^{\circ} 10.792 / 03$.

${ }^{213}$ PAUlo SERGIO XAVIER DE SouZA, A vinculação do juiz... cit.,p.272.
} 
O professor Alvino Augusto de Sá sintetiza muito bem a controvérsia: "Não existe, a meu ver, no sistema penitenciário, um consenso sobre a natureza do exame criminológico e do parecer de CTC. Na prática, ambos são tratados da mesma forma, embora, a partir da Lei Penal de Ciência Criminológica, tenham objetivos distintos. O parecer da CTC deveria voltar-se eminentemente para a execução, para a terapêutica penal e seu aproveitamento por parte do sentenciado. Já o exame criminológico é peça pericial, analisa o binômio delito-delinquente e o foco central para o qual devem convergir todas as avaliações é a motivação criminal, a dinâmica, criminal, isto é, o conjunto de fatores que nos ajudam a compreender a origem e desenvolvimento da conduta criminal do examinando."214

Ao contrário do exame criminológico, o parecer da CTC não constitui perícia, tratase apenas de um comentário conclusivo sobre condições verificadas, com a finalidade de subsidiar uma opinião técnica. De acordo com Alvino Augusto de Sá qualquer ideia de perícia no parecer das CTC seria tecnicamente inviável e eticamente inadmissível. ${ }^{215}$

O que ocorre na realidade, contudo é que os pareceres da CTC convertem-se em peça pericial, já que, afastada a CTC de suas verdadeiras funções e incumbida indevidamente de somente elaborar os tais pareceres, torna-se lógica e racionalmente impossível que venha a elaborá-los como se deve, pois falta toda a "matéria prima" para elaborá-los: exame de personalidade, classificação, elaboração dos programas individualizadores, acompanhamento do preso, avaliação dos programas, etc. ${ }^{216}$

Alvino Augusto de Sá explica que a linha divisória entre o exame criminológico e as demais formas de avaliação reside no fato de que a perícia criminológica restringe-se ao binômio crime-criminoso enquanto diagnóstico criminológico, e a ela interessa o prognóstico quanto ao grau de emendabilidade, o prognóstico de reincidência. Já as demais avaliações tornam mais claras quais são as possibilidades e as estratégicas de recuperação do preso. $^{217}$

Resta evidente que a natureza dos exames parece situar-se em uma zona meio nebulosa e um tanto quanto complexa, não havendo um consenso sobre a natureza dos exames, pois, na prática, acabam sendo tratados da mesma forma, embora nos termos da lei e da Ciência Criminológica tenham objetivos distintos. ${ }^{218}$

\footnotetext{
${ }^{214}$ Alvino AuguSto DE SÁ, Equipe criminológica... cit. p43.

${ }^{215}$ AlVINO AUGUSTO DE SÁ, Os três instrumentos... cit., p.167-8.

${ }^{216}$ Idem, p. 168.

217 Alvino Augusto de SÁ, Criminologia Clínica... cit., p.198.

218 PAUlo Sergio XAVIER DE SouZA, A vinculação do juiz... cit.,p..274.
} 


\section{CAPÍTULO V - O EXAME CRIMINOLÓGICO E A LEI N 10.792/03}

\section{Abolição do Exame Criminológico para instruir incidentes de execução}

De plano, deve-se ressalvar que o exame criminológico não foi abolido por completo pela Lei $n^{\circ} 10.792 / 03$, afinal, o artigo $8^{\circ}$ da Lei de Execução Penal não foi atingindo por esta lei. O que houve foi uma redução, por parte do legislador, nos casos em que se obrigava a sua realização. Assim, o exame criminológico persiste positivado no nosso ordenamento quanto à classificação do preso. O debate acerca da abolição se instala nos casos de exame criminológico para avaliação do requisito subjetivo nas penas privativas de liberdade por ocasião do cumprimento do lapso temporal para obtenção dos benefícios.

A Lei de Execução Penal estabeleceu, originariamente, em seu artigo 112, que a pena privativa de liberdade será executada em forma progressiva, com a transferência para regime menos rigoroso, a ser determinada pelo Juiz, quando o preso tiver cumprido ao menos um sexto da pena no regime anterior e seu mérito indicar a progressão.

Na redação original do artigo 112, parágrafo único, da LEP, ${ }^{219}$ eram obrigatórios ${ }^{220}$ o parecer da CTC ou o exame do COC para instruir o incidente de execução de progressão de regime, e assim compor a decisão judicial. Nessa sistemática, a realização de exames criminológicos para avaliação da possibilidade de progressão de pena de condenados era requisito legal.

A Lei $\mathrm{n}^{\circ}$ 10.792/03 alterou a individualização do sistema progressivo, ao dar nova redação ao caput do artigo 112, da LEP, além de substituir o parágrafo único do referido artigo por dois parágrafos ${ }^{221}$. O primeiro prevê que a decisão relativa à progressão de

\footnotetext{
${ }^{219}$ Art. 112 - A pena privativa de liberdade será executada em forma progressiva, com a transferência para regime menos rigoroso, a ser determinada pelo juiz, quando o preso tiver cumprido ao menos um sexto da pena no regime anterior e seu mérito indicar a progressão.

Parágrafo único. A decisão será motivada e precedida de parecer da Comissão Técnica de Classificação e do exame criminológico, quando necessário.

${ }^{220}$ Predomina na doutrina e na jurisprudência o entendimento de que antes da Lei no $10.792 / 03$ a confecção os laudos criminológicos eram obrigatórios para a apreciação dos benefícios prisionais. No entanto, em análise à redação original do artigo 112, parágrafo único, questiona-se se de fato existia essa obrigatoriedade, considerando o termo "quando necessário" ao final do dispositivo.

${ }^{221}$ Art. 112. A pena privativa de liberdade será executada em forma progressiva com a transferência para regime menos rigoroso, a ser determinada pelo juiz, quando o preso tiver cumprido ao menos um sexto da pena no regime anterior e ostentar bom comportamento carcerário, comprovado pelo diretor do estabelecimento, respeitadas as normas que vedam a progressão.
}

$\S 1^{\circ}$ A decisão será sempre motivada e precedida de manifestação do Ministério Público e do defensor. 
regime deve ser fundamentada e precedida de manifestação do Ministério Público e do defensor, enquanto o segundo estende o mesmo procedimento à concessão de livramento condicional, indulto e comutação das penas, respeitados os prazos previstos nas normas vigentes.

A nova redação dada ao artigo 112, da Lei de Execução Penal, pela Lei $\mathrm{n}^{\circ}$ 10.792/2003, não trouxe o exame criminológico como instrumento para aferição do mérito do condenado para se beneficiar com a progressão, exigindo somente que o preso tenha cumprido ao menos um sexto da pena no regime anterior e ostente bom comportamento carcerário, comprovado pelo diretor do estabelecimento.

Desse modo, o reeducando para ser promovido de regime precisa resgatar o requisito de ordem objetiva (temporal) e ostentar bom comportamento carcerário comprovado pelo diretor do estabelecimento prisional.

É certo que não existem palavras inúteis na lei, e o legislador ao escrever "comportamento comprovado", tinha a intenção de que o diretor trouxesse a luz dados concretos da execução que permitam concluir pelo bom comportamento. Assim, o bom comportamento deve ser devidamente comprovado, não bastando singelo atestado de conduta, emitido em folha padrão, em que somente se preenche lacuna com BOM/ MAU, sem oferecer nenhum dado concreto, nenhuma peculiaridade da execução de pena daquele sentenciado supostamente avaliado pela direção da prisão.

Como o novo texto não faz qualquer referência ao exame criminológico, muitos criminalistas entenderam que ele havia sido extinto ${ }^{222}$. Logo, passou-se, a sustentar que a Lei $\mathrm{n}^{\circ} 10.792 / 2003$ mudou profundamente a sistemática processual ao não exigir os exames para a concessão de progressão ou livramento condicional, bastando para a comprovação do requisito subjetivo o atestado de boa conduta assinado pelo diretor da unidade prisional onde se encontra o cativo.

A nova politica penitenciária com vistas a suprimir ou mitigar os laudos criminológicos lastreada na Lei $\mathrm{n}^{\circ} 10.792 / 03$ é implementada em um contexto em que as grandes rebeliões estavam se tornando frequentes e as facções criminosas surgidas no interior da cadeia demonstravam publicamente seu poder de dominação e articulação da massa carcerária. Neste momento, as cadeias estavam saturadas e o procedimento para a

$\S 2^{\underline{0}}$ Idêntico procedimento será adotado na concessão de livramento condicional, indulto e comutação de penas, respeitados os prazos previstos nas normas vigentes.

${ }^{222}$ Alvino Augusto De SÁ, Criminologia Clínica... cit., p.190. 
concessão de benefícios revelava-se extremamente burocrático, e a obrigatoriedade e eficiência dos laudos passou a ser questionada.

Várias razões motivaram o despontar da política penitenciária tendente a abolir a realização dos referidos exames, entre as quais, a de cunho teórico, é a constatação de que os saberes "psi” são incapazes, à luz de critérios minimamente rigorosos de confiabilidade e validade, de desvendar a subjetividade do sentenciado, de enunciar qualquer verdade consistente sobre ela e, principalmente, de prever o comportamento humano futuro. Sepultou-se, assim, tardiamente, o sonho positivista de detecção precisa da periculosidade, tanto pelas limitações técnicas e epistemológicas da tarefa, quanto pelas sérias reservas de natureza ético-jurídicas que marcam o exercício de tal pretensão, que vão desde sua inconsistência científica até sua natureza claramente atentatória à intimidade e dignidade humanas. $^{223}$

A princípio, a eliminação dos laudos criminológicos pela Lei $\mathrm{n}^{\circ}$ 10.792/03 foi bem recebida pelas entidades ligadas aos direitos de defesa dos presos, sendo entendida uma solução para aliviar o sistema penitenciário, na medida em que simplificaria o expediente, ao exigir mérito de conotação mais objetiva do que anteriormente, quando havia uma carga muito maior de subjetivismo, ${ }^{224}$ acelerando e facilitando a concessão de benefícios.

Enquanto alguns comemoravam, outros seguimentos da comunidade jurídica viram na alteração legislativa um grande risco à jurisdicionalização do processo de execução penal, na medida em que o mérito passaria a ser comprovado por documento expedido por funcionário do Poder Executivo, chegando-se questionar a constitucionalidade dessas modificações.

Na prática, o fim dos laudos, para além de suscitar o debate acerca do papel que o saber técnico ocupava na dinâmica prisional, na medida em que ele operava uma inevitável partilha de poder no interior do cárcere, pela qual a ordem disciplinar passava a sofrer limitações no seu exercício pleno, também representou uma etapa na consolidação de um projeto de excelência disciplinar que redundaria na instauração do RDD. ${ }^{225}$

A Lei $n^{\circ} 10.792 / 03$ ao mesmo tempo em que propõe o fim dos laudos criminológicos como requisito à concessão de benefícios prisionais introduz o Regime Disciplinar Diferenciado no ordenamento jurídico pátrio. Este fato não pode ser visto como

\footnotetext{
${ }^{223}$ AlEXANDRE ORSi NetTo e FlÁVIO AMÉRICO FrASSETO, Um engodo chamado exame criminológico, Boletim IBCCRIM n. 209, abr. 2010, p. 07-08.

${ }^{224}$ CARMEN SILVIA DE MORAES BARROS, As modificações ... cit., p. 181.

${ }^{225}$ AlessandRA TEIXEIRA. Do sujeito... cit., p.160.
} 
mera coincidência, mas sim compreendido como parte de uma nova política criminal que se visava instaurar.

Admitir que a Lei $n^{\circ} 10.792 / 2003$, ao alterar a redação do artigo 112, da LEP, aboliu por completo a exigência do exame criminológico do nosso ordenamento para fins de apreciação de pedidos de benefícios em sede de execução penal, é questão polêmica e enseja acalorado debate.

No primeiro momento, a supressão dos laudos criminológicos pela Lei $\mathrm{n}^{\circ}$ 10.792/03 foi vista pelos grupos e entidades defensoras dos direitos dos encarcerados como uma solução para desafogar o sistema, agilizando e aumentando a concessão de benefícios, uma vez que simplificado o expediente, o que, entretanto, acabou não se verificando, em razão de um acirramento maior na atuação do Ministério Público e do Poder Judiciário, que viu na lei um risco ao seu poder de decisão.

Como bem aponta Alvino Augusto de Sá, "a tendência é não se respeitar a reforma ocorrida em 2003, uma vez que, de uma maneira ou de outra está se tentando burlá-la"226, exigindo-se as avaliações técnicas para a concessão de benefícios.

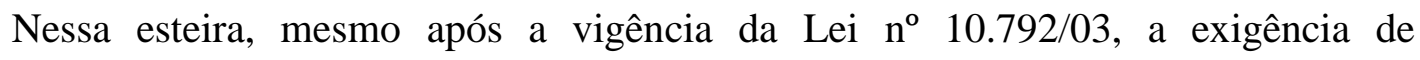
elaboração de laudos na instrução dos benefícios por parte dos juízes e promotores de execução tem sido corriqueira, o que estimulou, inclusive, a edição de Súmulas pelo Superior Tribunal de Justiça e Supremo Tribunal Federal, legitimando essa exigência, mediante pertinente fundamentação.

A questão é tão delicada que envolve o princípio do livre convencimento motivado do juiz, também conhecido como persuasão racional, segundo o qual compete ao juiz da causa valorar com ampla liberdade os elementos de prova constantes nos autos, desde que o faça motivadamente, com o que se permite a aferição dos parâmetros de legalidade e de razoabilidade adotados nessa operação intelectual.

Hoje, ainda que a perícia criminal não seja mais obrigatória para a progressão de regime, o papel da avaliação psicológica e psiquiátrica continua apresentando peso significativo na decisão judicial e na própria construção da individualização da pena. ${ }^{227}$

Dessa forma, existem os que defendem a extinção definitiva do laudo criminológico para instruir pedidos de benefícios e os que defendem que a alteração legislativa apenas retirou a obrigatoriedade da exigência do laudo, mas não impediu que o magistrado,

\footnotetext{
${ }^{226}$ Alvino Augusto de SÁ, Criminologia Clínica... cit., p.191.

227 JUlio CÉSAR Diniz HoEnISCH, A Psicologia entre Nuvens e Granito: Problematizando as Perícias Criminais, in Crítica à execução penal, $2^{\mathrm{a}}$ ed, Rio de Janeiro:Lumen Iuris, 2007, p.193.
} 
quando entendesse necessário, solicitasse o exame criminológico, logo esta seria uma faculdade do julgador.

Para entender o impacto da alteração trazida pela Lei $n^{\circ}$ 10.792/03 à dinâmica da concessão de benefícios em sede de execução penal, serão estudados os argumentos favoráveis e desfavoráveis à confecção do exame criminológico.

\subsection{Corrente Favorável}

O principal argumento em prol da extinção do exame criminológico respalda-se no princípio da legalidade.

A Lei $n^{\circ} 10.792 / 03$ ao dar nova redação ao artigo 112, da Lei de Execução Penal não previu o exame criminológico como instrumento para aferição do mérito do condenado para se beneficiar com a progressão, exigindo somente que o preso resgate o requisito de ordem objetiva (temporal) e ostente bom comportamento carcerário comprovado pelo diretor do estabelecimento prisional.

Em uma interpretação literal da nova lei, o exame criminológico, como requisito para a concessão da progressão de regime, foi extirpado do ordenamento jurídico brasileiro e sua exigência atenta contra o princípio da legalidade e configura constrangimento ilegal.

No tocante ao risco à jurisdicionalidade da execução, os que defendem o acerto da alteração legislativa na sistemática da exigência legal da realização de exames criminológicos para avaliação de possibilidade de progressão de pena de condenados argumentam que não foi subtraído do Poder Judiciário a análise de mérito para a progressão de regime e para o livramento condicional. O que ocorreu, na realidade, foi que o mérito passou simplesmente a ser observado a partir de critérios mais objetivos e transparentes, consistentes no cumprimento ou não dos deveres impostos pela lei ao preso.

Argumentam que não houve infringência ao princípio da jurisdicionalização, porque continua a competir juiz da execução, nos termos do artigo 66 da Lei de Execução Penal, decidir sobre a progressão criminal, deferindo-a ou não, além de fazer o controle de legalidade das sindicâncias instauradas para apuração de eventuais faltas disciplinares, bem como sanções, o que refletirá, obviamente, na classificação do comportamento do detento.

Há inclusive quem assevere que a opção normativa feita na redação original da Lei de Execução Penal, que determinava que decisão acerca da progressão deveria ser precedida de exames periciais, é que representava verdadeiro atentado à 
jurisdicionalização, uma vez que atribuía à decisão judicial sobre o provimento dos 'benefícios' legais do preso necessário vínculo aos laudos técnicos das comissões legalmente instituídas, ${ }^{228}$ "peças processuais cuja eficácia histórica foi a de manter absoluta sobreposição do discurso da criminologia administrativa sobre o sistema jurisdicional". ${ }^{229}$

Aqueles que apoiam as modificações introduzidas na Lei de Execução Penal pela Lei ${ }^{\circ} 10.792 / 2003$ acreditam que o Congresso Nacional não foi leviano ao abolir o exame criminológico do condenado, uma vez que com a novel legislação simplesmente se admitiu a possibilidade de se avaliar o mérito sem a necessidade do exame criminológico, considerando que este há muito tempo não cumpria com seu papel a contento.

A gênese da Lei $n^{\circ}$ 10.792/03 estaria calcada em duas ordens de motivos: o primeiro deles seria a constatação da falta de estrutura das CTCs no país, da precariedade de seu funcionamento e da má qualidade de seu trabalho, resultando o teor dos laudos realizados em meras repetições e avaliações superficiais sobre o preso. $\mathrm{O}$ segundo motivo estaria revestido na preocupação sobre a legitimidade e a importância desse tipo de saber, consistente na avaliação médica e científica, na definição dos destinos de cada preso, considerando a subjetividade intrínseca a esse tipo de parecer e dos óbices que o mesmo costumava trazer quanto aos prognósticos de recuperação dos reclusos. ${ }^{230}$

O exame criminológico era elaborado em precárias condições: falta de profissionais qualificados, entrevistas superficiais, impossibilidade de análise aprofundada em razão da rapidez das entrevistas, falta de acompanhamento do preso, o que tornava a qualidade do laudo, no mínimo, questionável, levando à tomada de decisão em processos de soltura ou de manutenção de pessoas na clausura que pode não corresponder às condições adequadas para o retorno da convivência social.

Assim, a corrente favorável à extinção do exame criminológico entende ser ilusório o argumento de que o exame criminológico poderia auxiliar o juiz fundamentar adequadamente sua decisão, pois há muito tempo a perícia não cumpria com seu papel a contento, exercendo na verdade uma função meramente simbólica. Acenam que os laudos consistiam em modelos padronizados, cujo conteúdo quase nada variava de um sentenciado para outro, logo, de pouca valia para individualização executória e contavam

\footnotetext{
${ }^{228}$ Salo de Carvalho, Práticas Inquisitivas na Execução Penal (Estudo do Vínculo do Juiz aos Laudos Criminológicos a partir da Jurisprudência Garantista do Tribunal de Justiça do RS), in Crítica à execução penal, $2^{\mathrm{a}}$ ed, Rio de Janeiro:Lumen Iuris, 2002, p.148.

229 Salo De Carvalho, O (novo) Papel dos "Criminologos" na Execução Penal: As alterações estabelecidas pela Lei 10.792/03, in Crítica à execução penal, $2^{\mathrm{a}}$ ed, Rio de Janeiro:Lumen Iuris, 2007, p.168.

${ }^{230}$ Alessandra TeIXEIRA. Do sujeito... cit., p.158.
} 
com excesso de subjetivismo, que acabava por convencer o juiz a segurar o preso no regime mais severo, o que agravava ainda mais a superlotação das cadeias.

Em sua maioria, os laudos apresentavam forte conteúdo moral, com viés altamente subjetivo e expectativas simplistas quanto a possibilidade de prever o comportamento futuro do preso, desconsiderando que a conduta reincidente decorre de um conjunto mais amplo, complexo e diversificado de fatores. Nessa toada, Salo de Carvalho faz pertinente ressalva que "a emissão do parecer cujo mérito sejam probabilidades não poderia justificar a negação de direitos públicos subjetivos, visto que tais hipóteses são inverificáveis empiricamente". 231

Ademais em vez de auxiliar o juiz, a confecção dos exames criminológicos incentivava um círculo vicioso de transferência de responsabilidade entre juízes e técnicos, sobre o condenado que seria reintegrado à sociedade, caso algo saísse errado, foram os técnicos que erraram e não o juiz, e vice-versa. ${ }^{232}$

Eliminada a obrigatoriedade, incluindo-se em seu lugar a indispensabilidade de atestado de boa conduta carcerária, fornecido pela direção do presídio, passa-se a exigir do juiz da execução penal maior liberalidade em relação ao preso. Ou seja, em vez de confiar cegamente num laudo técnico, transferindo a responsabilidade, o juiz seria obrigado agora a procurar fatos concretos constantes nos autos da execução do sentenciado para deferir-lhe ou não o seu benefício.

Mesmo quem reconhecia algum valor no exame criminológico enquanto peça pericial reconhece que a confecção dos exames aumentava a morosidade no processo de execução, e a nova lei dispensou-o, no intuito de acelerar a apreciação dos pedidos de concessão dos benefícios. Assim, a medida revestiu-se de dupla valia: foi sensível ao legítimo interesse dos condenados e, ao mesmo tempo, contribuiu para o desafogo dos estabelecimentos prisionais e da máquina judiciária. ${ }^{233}$

\footnotetext{
${ }^{231}$ SAlO DE CARVALHO, Práticas Inquisitivas ... cit., p.152.

${ }^{232}$ Ao defender o acerto da Lei $\mathrm{n}^{\circ}$ 10.792/03 em eliminar o exame criminológico, ANDREI ZENKNER SCHMIDT comenta que "os laudos criminológicos funcionavam como travesseiros para que os operadores da execução penal tenham o 'sono dos justos'.”. Acrescenta que argumentos no sentido de que após a Lei $n^{\circ}$ 10.792/03 o juiz não terá mais condições de aferir a periculosidade de um preso não procedem e que "tais afirmações, na verdade, são uma forma de resistência contra a assunção de responsabilidades, um subterfúgio discursivo para escamotear a própria irracionalidade. Sim, porque agora, quando um preso, em regime semiaberto, tornar a delinquir, não teremos mais um perito para arcar com o equívoco da progressão do regime. A (irresponsabilidade de um juiz que veda uma progressão de regime para um preso que tinha condições para tanto é invisível e incontestável cientificamente; contudo, a mesma (ir)responsabilidade de um juiz que permite um regime semiaberto para um preso que volta a delinquir, esta sim, é verificável empiricamente e, agora, não há mais com quem dividi-la.". (Crônica acerca da extinção do exame criminológico, Boletim do Instituto Brasileiro de Ciências Criminais n.134, jan. 2004, p.03.).

${ }^{233}$ Luís Fernando de Moraes Manzano, Prova pericial...cit.,p.49.
} 
Para esta corrente, a alteração trazida pela Lei $\mathrm{n}^{\circ}$ 10.792/03 atende à efetividade da execução penal e da própria pena, uma vez que tende a evitar que o condenado que mereça o benefício deixe de alcançá-lo no tempo almejado, em razão da demora do Estado na realização do exame.

Destarte, a mudança na legislação veio a atender um procedimento de coerêncialógica, de que a não elaboração em prazo razoável do exame criminológico, levaria a sua dispensa, a fim de não ferir direito maior do sentenciado, que não deu azo ao retardamento da perícia, não podendo ser por ele punido com a restrição de direitos.

\subsection{Corrente contrária}

Para ser promovido de regime ou obter o livramento condicional, o condenado deve preencher o requisito objetivo, consistente no resgate do lapso temporal determinado pela legislação, e o requisito subjetivo. No tocante ao requisito subjetivo, o juiz precisa de elementos que indiquem o merecimento do reeducando, elementos que forneçam ao julgador a certeza de que aquele interno está preparado para a progressão, e, portanto, apto para retornar ao convívio social.

Para os defensores do exame criminológico, ele seria a única forma de, tecnicamente e com segurança, constatar as condições pessoais do apenado, ou seja, se está realmente apto para a obtenção do benefício, respaldando a fundamentação do magistrado em decisão acerca da antecipação da liberdade do sentenciado e da progressão regimental.

Entendem que não houve a extinção da exigência legal do exame criminológico para instrução de incidentes de execução, pois ainda há no ordenamento jurídico a exigência da aferição do mérito do condenado para concessão de benefícios, uma vez que não houve a derrogação do $\S 2^{\circ}$ do artigo 33 do Código Penal que estatui que "as penas privativas de liberdade deverão ser executadas em forma progressiva, segundo o mérito do condenado $(,,$,$) ".$

Aduz a corrente avessa às modificações introduzidas pela Lei $\mathrm{n}^{\circ}$ 10.792/03 no tocante à sistemática de progressividade que o conceito de mérito é mais amplo que o de bom comportamento. Bom comportamento carcerário significa apenas e tão somente portar-se o sentenciado de acordo com as regras de disciplina interna previamente estipuladas. 
O mérito para a progressão não deve ser aferido apenas e tão somente em função de eventual bom comportamento carcerário, mas sim em decorrência da aptidão do condenado em retornar ao convívio comunitário sem risco para a sociedade.

Sobre o tema, leciona Julio Fabbrini Mirabete que "a simples apresentação de um atestado ou parecer do diretor do estabelecimento penitenciário, após o cumprimento um sexto da pena no regime anterior, não assegura ao condenado o direito de ser promovido a regime menos restrito. Embora se possa inferir da nova redação do dispositivo intuito de redução do mérito, previsto na lei anterior, ao bom comportamento carcerário, no sistema vigente a progressão de regime pressupõe, como visto, não somente o ajustamento do condenado às regras do regime carcerário em que se encontra, mas também um juízo sobre sua capacidade provável de adaptação ao regime menos restrito. Essa avaliação mais abrangente e aprofundada, e, portanto, mais individualizada, das condições pessoais do condenado para a progressão, é inerente ao sistema progressivo instituído pela reforma penal de 1984; reclamada pela exigência de mérito, persistente no Código Penal (art.33, $\S 2^{\circ}$ ); expressamente prevista para a progressão ao regime aberto (art. 114, II da LEP) e compatível com o princípio constitucional da individualização da pena (art. $5^{\circ}$, XLVI, da CF)". 234

A boa conduta significaria tão somente que o preso está obedecendo às regras prisionais. Ao tentar se adaptar à vida carcerária, considerando a má gestão dos estabelecimentos prisionais e fenômenos como a prisionalização, pode o preso sucumbir à cultura do cárcere, o que afeta sua identidade, mitigando-a ou mesmo substituindo-a por outra. Essa perniciosa adaptação implica uma desadaptação da vida em liberdade.

Destarte, o sentenciado busca-se adaptar ao conjunto de regras próprias vigentes entre os presos, com o intuito de ser aceito pelo grupo, e, assim, resguardar sua integridade física ou mesmo sua vida. Portanto, nas palavras de Manoel Pedro Pimentel, "longe de estar sendo ressocializado para a vida livre, está, na verdade, sendo socializado para viver na prisão. O preso aprende rapidamente as regras disciplinares vigentes na prisão, para obedecê-las e não sofrer punições. Assim, o observador desprevenido pode supor que um preso de bom comportamento é um homem regenerado, quando o que se dá é algo inteiramente diverso: trata-se, apenas, de um homem prisonizado". ${ }^{235}$

Para criminalistas como Alvino Augusto de Sá essa boa conduta tanto poderá representar um real crescimento interior, como uma boa adaptação, no sentido pejorativo, à

${ }^{234}$ JUlio FABBrini MiRABeTe, Execução Penal... cit., p. 424.

${ }^{235}$ MANOEL PEDRO PIMENTEL, Sistemas penitenciários... cit., p.268. 
vida carcerária, uma boa capacidade de harmonizar as regras do poder paralelo, ou seja, uma identificação com a vida do crime. ${ }^{236}$

Seguindo essa linha de pensamento, o atestado de conduta não representaria um comprovante seguro e convincente de que o preso realmente está assimilando valores para uma boa convivência social.

Questiona-se também a constitucionalidade da nova redação do artigo 112 da Lei de Execução Penal, acenando violação ao princípio consagrado no artigo $5^{\circ}$, XLVI, consistente na individualização da pena.

Na lição de Sérgio Marcos de Moraes Pitombo, “individualizar, na execução, consiste no dar a cada preso as oportunidades e elementos necessários para lograr a reinserção social, posto que é pessoa, ser distinto. A individualização, portanto, deve aflorar técnica e científica, nunca improvisada." 237

Pondera-se que aos atestados de boa conduta seriam imprestáveis para a finalidade a qual estão destinados, pois são lacônicos e produzidos em escala industrial. Não há fundamentação na manifestação do diretor do presídio que opina genericamente em relação à situação do preso.

Além de atentar contra a individualização da pena, a nova sistemática tende a transformar o juiz num mero homologador de atestado administrativo, num claro vilipêndio aos princípios da execução penal, como por exemplo, a jurisdicionalidade da execução da penal e o princípio do livre convencimento.

De acordo com Nucci a alteração no artigo 112, da Lei de Execução Penal feita pela Lei $n^{\circ} 10.792 / 03$ “foi péssima para o processo de individualização executória da pena. E, nessa ótica, inconstitucional. Não se pode obrigar o magistrado, como se pretendeu com a edição da Lei 10.792/03, a conceder ou negar benefícios penais somente com apresentação do frágil atestado de conduta carcerária. A submissão do Poder Judiciário aos órgãos administrativos do Executivo não pode jamais ocorrer". ${ }^{238}$

Vincular o magistrado a um atestado de conduta emitido pelo diretor da unidade é ferir a autonomia do Poder Judiciário com relação ao Poder Executivo, na medida em que lei que dá maiores poderes ao diretor do presídio de decidir quem merece ou não ser promovido, ela engessa a atividade jurisdicional, tornando a execução da pena

\footnotetext{
${ }^{236}$ Alvino Augusto de SÁ, Criminologia Clínica... cit., p.201.

${ }^{237}$ SÉRGIO MARCOS DE MORAES PITOMBO, Os regimes de cumprimento de penas e o exame criminológico, Revista dos Tribunais n.583, mai. 1984, p.313.

${ }^{238}$ GuILHERME De SOUZA NUCCI, Leis Penais ... cit.,p. 409.
} 
administrativa. Além disso, a alteração legislativa cercearia o acesso do sentenciado à jurisdição, descaracterizando o preso enquanto sujeito de direitos, e ressuscitando modelo administrativo.

Para essa corrente, a alteração legislativa ao suprimir a exigência do laudo criminológico para fins de benefícios, longe de beneficiar os sentenciados, na verdade mitiga suas garantias, deteriorando a jurisdicionalização da execução, uma vez que restabeleceu a soberania administrativa, considerando que o administrador volta a concentrar grande poder com relação à dinâmica prisional.

Somado aos argumentos acima, acreditam também que, sob a desculpa de tornar o procedimento menos burocrático, a alteração legislativa teve como real objetivo esvaziar as cadeias e não melhorar o sistema prisional. ${ }^{239}$

Para essa corrente, a abolição do exame criminológico demonstra-se uma solução de cunho imediatista, cedendo às pressões exercidas por governos estaduais que não pretendem investir no sistema penitenciário, e não pode receber o beneplácito do EstadoJuiz.

Em outras palavras, a extinção do exame criminológico como condição para a obtenção de progressão de regime e livramento condicional, foi o meio eleito para agilizar a liberação de condenados e possibilitar a exequibilidade das medidas de combate à criminalidade organizada. ${ }^{240}$ Não seria coincidência, portanto, que a Lei no ${ }^{\circ} 10.792 / 03$ tenha ao mesmo tempo instituído o Regime Disciplinar Diferenciado, que necessita de maior espaço nos presídios para poder ser implementado, e alterado a sistemática da concessão de benefícios legais no âmbito da execução, tornando-a menos exigente.

Quanto ao argumento de que o exame era mal elaborado, esclarecem que se os exames eram padronizados em alguns casos, o ideal é que houvesse investimento estatal para corrigir a defasagem, aperfeiçoamento os laudos e não suprimi-los.

Ressaltam que a elaboração do exame criminológico seria uma exigência salutar para que o julgador tenha o mínimo de elementos para não inserir um condenado despreparado num estágio, onde a vigilância é mínima, com efeitos deletérios na segurança

\footnotetext{
${ }^{239}$ Nesse sentido, GUILHERME DE SOUZA NUCCI aponta a incoerência de abolir-se somente o exame criminológico para fins de benefícios, mas mantê-lo para o momento de inserção no sistema carcerário, apontando que se os laudos "eram tão imprestáveis para a progressão, deveriam ter a mesma avaliação para a inicialização da execução penal. Ora quem padroniza para a progressão pode perfeitamente padronizar para o início do cumprido da pena.". (Leis Penais... cit., p. 409).

${ }^{240}$ FABIANA LEMES ZAMALlOA PRADO, Execução penal e garantismo: as alterações introduzidas na lei de execuções penais sobre o exame criminológico Boletim IBCCrim, n.146, jan. 2005, p. 06.
} 
da comunidade e no sentimento de impunidade que já se dissemina por toda a população ordeira deste país com inegável desprestígio do próprio Estado-Juiz.

Por fim, argumentam que foi eliminada apenas a obrigatoriedade da exigência do exame para fins de progressão do regime, mas não houve vedação, assim, o exame criminológico pode ser realizado facultativamente pelo magistrado, desde que por decisão fundamentada.

\section{Facultatividade de sua realização}

Quem sustenta a possibilidade da realização facultativa do exame criminológico para instruir os incidentes de progressão e livramento condicional, afirma que, após a Lei n ${ }^{\circ}$ 10.792/03, a Lei de Execução Penal não proíbe a realização do exame, pelo contrário, permite, embora não obrigue sua confecção.

A nova redação dada ao artigo 112 da Lei de Execução Penal deve ser interpretada da seguinte forma: se de um lado não há mais a obrigatoriedade do exame criminológico, de outro não há vedação legal expressa à perícia. Portanto, nada impede que o juiz da execução, com o escopo de aquilatar a presença ou não do mérito, se aproveite de outros elementos de convicção, como o laudo pericial elaborado por profissionais que se utilizam de técnicas científicas, a fim de proclamar com mais acerto a decisão judicial que permite ao condenado a passagem para outra etapa no caminho da ressocialização.

Convém ao magistrado acautelar-se, ponderando os riscos a que submeterá a sociedade em conceder a benesse, pura e simplesmente com base em atestado de conduta e não em estudo técnico-científico. Assim, não foi vedado ao magistrado o recurso à opinião de especialistas para a formação do seu convencimento.

O juiz precisa de elementos que atestem o mérito do sentenciado, dados que permitam ao julgador ter o máximo de certeza possível de que aquele interno está preparado para retornar ao convívio social sem representar uma ameaça à sociedade. Para angariar elementos assertivos sobre a para aferição da situação do apenado, a elaboração do exame criminológico mostra-se um importante instrumento.

Por outro lado, não sendo a perícia exigência legal indeclinável, o juiz não está adstrito a determiná-la, ainda que requerida pelo Ministério Público. Se outros elementos forem suficientes para a formação segura da convicção do juiz, não será necessária a elaboração de perícia. Assim, a elaboração do exame criminológico é orientada pelo 
critério da necessidade, não havendo ilegalidade na sua exigência, desde que determinada de maneira fundamentada.

Para exigir o exame criminológico sugere-se como critério norteador a gravidade do delito pelo qual restou o réu condenado, assim a realização do exame criminológico se daria apenas para certas categorias de delinquentes. Essa sugestão encontra respaldo no fato de que o condenado ao cumprimento de pena privativa de liberdade em regime fechado quando da entrada no sistema carcerário deverá se submeter obrigatoriamente ao exame criminológico, enquanto o sentenciado ao cumprimento de pena em regime semiaberto poderá ser submetido ao exame criminológico, conforme previsão do artigo $8^{\circ}$ da LEP.

Considerando o exame criminológico ser obrigatório para os condenados em regime fechado e facultativo para os condenados em regime intermediário, constata-se que a gravidade do fato delituoso ou as condições pessoais do agente, determinantes da execução em regime fechado, aconselham o exame criminológico. ${ }^{241}$

Esse raciocínio merece cuidado especial, sob o risco de se tornar discriminatório e incoerente, pois poderia estar-se, de antemão, considerando de maior ou menor periculosidade certos tipos de delinquentes, esquecendo que a condição básica para o sucesso do exame é a presunção de recuperação e ressocialização, considerando o empenho pessoal de cada preso, independente de seu passado, em demonstrar-se apto para o retorno ao seio social.

Os que repudiam essa ideia alertam que não se deve limitar a obrigatoriedade do exame criminológico a certas categorias de delinquentes, sob pena de estarmos realizando um pré-julgamento, embora a realidade dos países muitas vezes obrigue a essa limitação. ${ }^{242}$

Outros entendem que a avaliação do tipo de crime, sua natureza e consequência são elementos a serem aferidos quando do processo de conhecimento, durante a emissão de decisão, na dosimetria da pena. Desse modo, utilizar esses critérios para determinar a confecção do exame criminológico escaparia por completo ao âmbito da execução penal, pois nesta fase deve-se ter em vista o comportamento e a conduta do condenado durante o cumprimento de pena. Somente os acontecimentos havidos durante a execução da pena poderão ser objeto da análise para fins de reconhecimento do mérito do reeducando.

Nesta esteira, esclarece Marcos Zilli que "o mérito ou o demérito, impulsionadores da maior aproximação ou distanciamento do condenado do convívio social, são extraídos

\footnotetext{
${ }^{241}$ SÉRgio MARCOS DE MORAes Pitombo, Os regimes... cit, p.314.

${ }^{242}$ VILSON FARIAS, O exame criminológico... cit.,.p289.
} 
em face dos elementos colhidos ao longo da execução penal. Afinal, o juízo que recai sobre o reconhecimento ou não da prática de uma infração penal não é - nem poderia ser o mesmo que recai sobre a constatação ou não de convergência de requisitos objetivos e subjetivos para a reintegração social". ${ }^{243}$

Portanto, o magistrado ao julgar as pretensões relativas aos institutos que reinserem os condenados gradualmente à sociedade, deve se pautar no modo como cada sentenciado cumpre sua pena e não aos fatos pelos quais foram condenados ou à quantidade de pena aplicada no juízo condenatório, sob pena de inaceitável bis in idem, tendo em vista que na sentença condenatória essas situações já foram devidamente analisadas. ${ }^{244}$

É a posição endossada por Gustavo Octaviano Diniz Junqueira que assevera que as circunstâncias utilizadas como fundamento para a exigência do exame só podem se referir ao comportamento carcerário do sentenciado, e não ao crime praticado, eis que o mérito a que se refere o artigo 112, da LEP, examina, claramente, o período após o cometimento do crime, e não pode levar em conta o crime em si, sob pena de bis in idem. ${ }^{245}$

O novo texto legal tão-somente suprimiu a obrigatoriedade dos exames técnicos, não vedando, contudo, que o julgador, no exercício da jurisdição e à luz do caso concreto, determine sua realização sempre que entenda necessária para avaliar o mérito do reeducando. $^{246}$

Ao garantir ao juiz a faculdade de determinar a realização do exame criminológico, preserva-se a independência funcional do juiz na avaliação concreta do progresso e merecimento do condenado à progressão da pena, não limitando o julgador ao atestado de conduta emitido pela autoridade administrativa, bem como se respeita o princípio do livre convencimento do magistrado na apreciação das provas.

A decisão que solicitar a realização de exame criminológico deve apontar as circunstâncias do caso concreto que indiquem a necessidade da citada perícia, eis aqui a função da motivação como forma de controle.

\footnotetext{
${ }^{243}$ Marcos AleXANDre CoElHo ZILli, A iniciativa instrutória... cit., p. 251.

244 AleXANDRE ORSi NeTTO, A falácia...cit., p. 14-15.

245 Gustavo Octaviano Diniz JunQUeIRA, Legislação Penal Especial, vol 1, 6aaed., São Paulo: Saraiva, 2010 , p.73.

246 LOURI GERALDO BARBIERI, Execução penal: sistema progressivo e mérito do reeducando, Cadernos Jurídicos. v.7. n.26, jan./abr.2006, p.100.
} 


\subsection{Entendimento Jurisprudencial}

Segundo o entendimento jurisprudencial predominante, a Lei 10.792/03 não excluiu a possibilidade de elaboração do exame criminológico, ficando a critério do magistrado decidir, de maneira fundamentada, sobre a questão, podendo inclusive determinar a realização de outras diligências para a aferição das condições psicológicas do sentenciado.

O Superior Tribunal de Justiça já se manifestou no sentido de o exame criminológico, enquanto perícia, constituir um instrumento necessário para a formação da convicção do magistrado, de maneira que pode ser realizada como forma de se obter avaliação mais aprofundada acerca da provável capacidade do sentenciado de adaptação ao regime menos severo. ${ }^{247}$

Uma vez realizado o exame, suas conclusões não devem ser desprezadas, pois, de acordo com precedente do Superior Tribunal de Justiça, "o exame criminológico e os laudos técnicos, anteriormente indispensáveis para se aferir o preenchimento do requisito subjetivo exigido para a concessão de benefícios, após o advento da nova legislação tornaram-se recursos excepcionais, mas, se realizados e desfavoráveis, nada obsta que sejam considerados na análise do pedido de progressão". ${ }^{248}$

O Superior Tribunal de Justiça esclarece que de fato a nova redação dada pela Lei $\mathrm{n}^{\mathrm{o}}$ 10.792/03 ao artigo 112 da LEP eliminou a obrigatoriedade do exame criminológico para a verificação do mérito do apenado no procedimento de progressão do regime carcerário, cabendo ao juiz da execução a ponderação casuística sobre a necessidade ou não de adoção de tais medidas. ${ }^{249}$

Quanto ao Supremo Tribunal Federal, a Súmula Vinculante número 26 expressa a ideia de que é possível ao magistrado requerer o exame criminológico, mas ressalta que essa exigência deve ser por decisão fundamentada.

A possibilidade da realização facultativa do exame criminológico para fins de progressão de regime ganhou forte impulso com a edição da Súmula Vinculante $26^{250}$, pelo

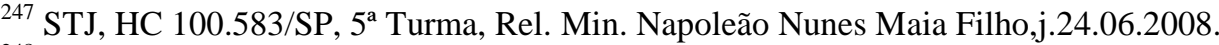

${ }^{248}$ STJ, HC 52560/PR, $6^{\text {a }}$ Turma, Rel. Min. Maria Thereza de Assis Moura, DJe 19.12.2008.

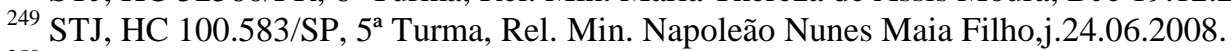

250 "Para efeito de progressão de regime de cumprimento de pena, por crime hediondo ou equiparado, praticado antes de 29 de março de 2007 , o juiz da execução, ante a inconstitucionalidade do artigo $2^{\circ}, \S 1^{\circ}$ da Lei 8.072/90, aplicará o artigo 112 da Lei de Execuções Penais, na redação original, sem prejuízo de avaliar se o condenado preenche ou não os requisitos objetivos e subjetivos do benefício podendo determinar para tal fim, de modo fundamentado, a realização de exame criminológico".
} 
Supremo Tribunal Federal e, após, da Súmula $439^{251}$ do Superior Tribunal de Justiça, que representam o reconhecimento jurisprudencial da relativização da necessidade do exame criminológico.

As súmulas compreendem a síntese de um entendimento reiterado do tribunal sobre determinado assunto, a pacificação do entendimento a esse respeito servirá como orientação para as demais instâncias da Justiça, daqui por diante.

Do cotejo entre a nova redação do artigo 112 da Lei de Execução Penal e a orientação jurisprudencial dada pelo Superior Tribunal de Justiça e pelo Supremo Tribunal Federal sobre a matéria, observa-se que ao juiz da execução, como regra geral, é facultado, desde logo, deferir a benesse apenas com base no adimplemento do lapso temporal exigido em lei e no atestado de bom comportamento carcerário a ser emitido pela autoridade penitenciária. Porém, não é vedado ao magistrado aferir o mérito do apenado por outros elementos de prova, considerando que o critério subjetivo à progressão de regime prisional continua a ter ligação com o juízo de avaliação sobre o perigo concreto que o retorno do sentenciado à sociedade ofendida possa trazer (mais uma vez) a esta.

251 “Admite-se o exame criminológico pelas peculiaridades do caso, desde que em decisão motivada". 


\section{CAPÍTUlo VI - VALOR PROBATÓRIO DO EXAME CRIMINOLÓGICO}

\section{Enquadramento do exame criminológico como prova pericial}

No processo penal, a disciplina da prova encontra-se regulada pelo Título VII, do Código de Processo Penal. No tocante especificamente à prova pericial os dispositivos legais estão inseridos no Capítulo II, do referido Título. Já na Lei de Execução Penal pouco se regula acerca da produção de provas, apenas fica evidente, do teor do artigo, 196, § $2^{\circ}$, da LEP, a possibilidade de ser determinada prova pericial e oral pelo juiz da execução criminal. Assim, na lacuna deixada pela LEP, serão observadas, em caráter complementar, as disposições sobre prova pericial presentes no CPP.

A prova pericial será elaborada por peritos, no bojo de processo judicial, observando-se os princípios do contraditório e da ampla defesa e deverá buscar comprovar algum fato relevante juridicamente.

Essas características estão presentes no exame criminológico, sendo o professor Alvino Augusto de Sá categórico ao afirmar ser o exame criminológico perícia, definindoo como um "instrumento de elementos de prova, na medida em que, por ele, colhem-se elementos instrutórios sobre a dinâmica do ato criminoso e, consequentemente, sobre a probabilidade de sua recidiva. Trata-se de uma manifestação técnica, com uma finalidade bastante definida e até restrita, feita por profissionais dotados de conhecimentos técnicos periciais pertinentes à questão. Presta-se ao deslinde de uma questão jurídica, na medida em que informa à autoridade competente sobre a dinâmica do ato criminoso, foco de atenção nas decisões judiciais tomadas no âmbito de execução". 252

Consiste o exame criminológico em estudo interdisciplinar, no qual se realiza a pesquisa dos antecedentes pessoais, familiares, sociais, psíquicos, psicológicos do condenado, para a obtenção de dados que possam revelar, o tanto quanto possível, a relação entre os antecedentes do sentenciado, a conduta delinquente e a dinâmica do ato criminoso.

Portanto, o exame criminológico é uma perícia, mais especificamente uma perícia complexa, isto é, aquela que abrange mais de uma área de conhecimento especializado.

${ }^{252}$ Alvino Augusto de SÁ, Os três instrumentos ... cit., p.166. 
Quando destinado à instrução de pedidos de benefícios abrange uma combinação entre estudos e exames jurídico, psiquiátrico, psicológico e social, objetivando uma conclusão sobre a conveniência ou não de concessão do benefício. Possui, assim, a função de subsidiar a formação do convencimento do magistrado, inserindo-se como prova em processo judicial, restando evidente, que incidirão sobre o exame criminológico todos os regramentos atinentes temática da prova, em conceito amplo, e, em especial, os da prova pericial.

\subsection{Qualidade dos laudos}

A precária qualidade dos exames criminológicos como instrumento de auxílio para formar a convicção do magistrado foi fator decisivo para promover a alteração legal que dispensou a obrigatoriedade do aludido exame para instruir incidentes sobre benefícios, consubstanciada na Lei $\mathrm{n}^{\circ} 10.792 / 03$.

É notório que a administração penitenciária não dispõe de pessoal capacitado e treinado para a realização do exame criminológico em quantidade suficiente ante a demanda, o que implica exames, que, quando são feitos, muito pouco ou quase nada de seguro apontam, sendo geralmente muito subjetivos e superficiais.

A carência por profissionais preparados em quantidade suficiente para atender a demanda pela realização de exames criminológicos é diretamente proporcional à má qualidade e à demora na elaboração dos laudos, acarretando diversos prejuízos à jurisdição.

A demora excessiva para se confeccionar o exame criminológico atinge suas duas modalidades, de entrada e de instrução para benefícios. O exame criminológico de entrada, que deveria servir como parâmetro para identificar melhoras ou pioras no preso ao longo do cumprimento de sua pena, tem seu valor mitigado, pois, geralmente é feito (quando é feito), muito tempo após a prática delitiva. Isso acontece, porque "infelizmente, a longa duração das prisões cautelares, ocasionadas pela demora no processo e julgamento dos acusados, e o desaparelhamento do sistema penitenciário têm feito com que o exame criminológico perca um pouco de sua confiabilidade, em virtude do tempo que separa a sua realização da prática de infração penal". ${ }^{253}$

\footnotetext{
${ }^{253}$ ARthur Bragança de Vasconcellos Weintraub e Josue Modesto Passos, O direito de execução... cit., p. 168.
} 
Sendo o foco do presente trabalho o exame criminológico para instrução de incidentes de benefícios, recorda-se que para progredir de regime prisional ou obter outro benefício basta o encarcerado resgatar o lapso temporal e apresentar mérito favorável, que na redação original da LEP era atestado pelo exame criminológico. Porém, observa-se um descompasso entre o preenchimento dos dois requisitos, pois, após resgatar o lapso temporal, o presidiário era submetido à perícia que era demorada, logo, quando conseguia o benefício já tinha passado muito mais tempo do que a lei exige em regime mais rigoroso. $^{254}$

Consoante já exposto, a execução penal ostenta o mérito da praticidade, optando o legislador por um processo com procedimento simples, prestigiando as provas préconstituídas, em geral, documentais, determinando a produção da prova oral ou da pericial, somente em casos de demonstrada necessidade, tudo a fim de contribuir para o julgamento rápido das questões. Destarte, a elaboração procrastinada do exame criminológico colide com o espírito da legislação, e diante desse contexto fático, manifesta-se a doutrina ser "evidente que o legislador imaginou que o vencimento da fração prevista e a realização do exame criminológico dar-se-iam simultaneamente ou quase assim. $\mathrm{Na}$ prática, os condenados aguardam de seis meses a um ano na Capital $^{255}$ para serem levados ao exame, como já se revelou, e se submetem, depois, aos percalços judiciais na avaliação do seu pedido.".256

É notório que o número de profissionais gabaritados para elaborar os exames criminológicos é consideravelmente menor do que a demanda, revelando o desaparelhamento do sistema penitenciário, registrando a doutrina que "um parecer demora, para progressão, na Detenção de São Paulo, mais de um ano. Há, trabalhando, uma equipe e meia de técnicos para atender a toda a população. Também há demora sensível nos outros presídios a enlouquecer o condenado". ${ }^{257}$

Destarte, a demora na confecção e a sobrecarga de serviço são fatores que contribuem para a má qualidade dos laudos, afinal, para conseguir dar conta da elaboração

\footnotetext{
${ }^{254}$ Com relação ao descompasso temporal entre o preenchimento do lapso temporal previsto na legislação e a concessão efetiva da progressão, ALESSANDRA TEIXEIRA menciona que em pesquisa realizada por ela juntamente com Eliana B.T. Bordini, publicada no artigo "Decisões Judiciais da Vara das Execuções Criminais: Punindo Sempre mais" In: São Paulo em Perspectiva, vol.18, $\mathrm{n}^{\circ} 1$, jan-mar d e 2004, constatou-se empiricamente que o lapso para a primeira concessão superava em muito a previsão legal: $75 \%$ dos presos que obtiveram a progressão já haviam cumprido mais $1 / 3$ de sua pena e não $1 / 6$ como dispõe LEP. (Do sujeito... cit., p.104)

${ }^{255}$ Referência ao Estado de São Paulo, cujo único Centro de Observação Criminológica (COC) localizava-se na Capital, o qual foi desativado pelo Decreto $\mathrm{n}^{\circ} 46.483$ de 2002.

${ }^{256}$ EdUARdo Pereira SANTOS, Execução Criminal, ... cit. p.114.

${ }^{257}$ Idem, p. 111.
} 
de um número infindável de laudos para instruir pedidos de benefícios, só mesmo elaborando laudos lacônicos, superficiais e muitas vezes de conteúdo repetitivo.

$\mathrm{O}$ exame criminológico transformou-se em um singelo parecer apresentado por assistente social, psicólogo, e, raramente, por psiquiatra, que muitas vezes não dispõem de conhecimento específico para a análise do comportamento do criminoso, restringindo seu trabalho em uma única entrevista.

Observa Marco Antônio Bandeira Scapini que "nos processos de execução, os laudos do Centro de Observações Criminológicas são quase sempre iguais. Psiquiatras, psicólogos e assistentes sociais conseguem dizer das condições pessoais dos apenados depois de entrevistas que duram, no máximo, trinta minutos". ${ }^{258}$ Situação que revela que as conclusões dos laudos eram as impressões resultantes de um único momento de contato.

Considerando a elaboração de forma mecânica e padronizada, em que se preservava mais o formalismo do que o conteúdo, o valor probatório do exame criminológico tornou-se questionável. Não eram raras as críticas que apontavam que os laudos não cumpriam sua função a contento, não permitindo a efetiva individualização executória, nem aferindo as condições do sentenciado para se reinserir socialmente.

O exame criminológico foi idealizado para orientar cientificamente a pena, de modo a fornecer subsídios ao magistrado para compreender o preso e, assim, poder ter maior chance de acerto na escolha das medidas a serem aplicadas no desenvolvimento do cumprimento da pena.

Enquanto prova pericial, o exame criminológico deve fornecer elementos de convicção ao juiz para que este decida acerca do pedido de progressão de regime ou de livramento condicional, tendo como referência a avaliação social, psicológica e psiquiátrica do preso, favorável ou desfavorável ao benefício postulado.

$\mathrm{Na}$ teoria, não se pode negar que o referido laudo é instrumento relevante para identificar e individualizar o condenado de modo a tornar mais proveitoso, sob o aspecto da busca da ressocialização, o tempo de cumprimento de pena. Todavia, na prática, o exame criminológico passou a ser feito de maneira protocolar e não era capaz de fornecer, na maioria dos casos, subsídios efetivos ao juiz para direcionar o tratamento a ser dado ao interno durante o cumprimento de pena. De outro lado, passou-se a exigir dos profissionais que confeccionam esses laudos uma postura diversa daquela que lhes competia, em clara

${ }^{258}$ MARCO ANTÔNIO BANDEIRA SCAPINI, Execução penal... cit.. p.54. 
distorção a suas funções ${ }^{259}$. Em vez prestar assistência à população carcerária, a atuação dos profissionais responsáveis pela confecção dos laudos se reduziu a decifrar os condenados e traçar juízos hipotéticos de condutas na perspectiva de sua reintegração social.

O exame criminológico em si é um bom instrumento para auxiliar o magistrado, no entanto, devido à má interpretação dada à Lei de Execução Penal pouco tempo depois de sua entrada em vigor, os técnicos foram empurrados para a mediocridade, sendo incumbidos de analisar personalidade de seres humanos em poucos minutos de entrevista; devendo em consequência dessa insólita análise emitir palpites sobre suas vidas e personalidade, bem como fazer previsões adivinhatórias sobre seu futuro. ${ }^{260}$

Percebe-se, que houve um desvirtuamento na finalidade do exame criminológico, que em vez de ofertar uma orientação científica para o processo de ressocialização, na verdade, passou a ser utilizado para aferir possíveis desdobramentos futuros da conduta do condenado, em termos de probabilidade de recidiva, transformando-se em um atestado absoluto da aptidão ou não para o gozo de determinado benefício, em uma garantia de que aquele apenado pode voltar para a sociedade sem expô-la novamente a riscos. Não é admissível a ideia de que um profissional da saúde poderia determinar o futuro, especialmente a partir de avaliações de discutível rigor técnico-científico. ${ }^{261}$

Interessante mencionar que para Alvino Augusto de Sá, o problema não está no oferecimento do prognóstico de reincidência em si, esclarecendo que o prognóstico é parte que naturalmente se segue a um diagnóstico, mas sim na expectativa e na exigência do judiciário de que o exame criminológico deve oferecer uma boa dose de certeza sobre a probabilidade do comportamento criminoso se repetir ou não no futuro. ${ }^{262}$

Os laudos também padecem da observância de procedimento adequado, despindose da característica de avaliação, uma vez que cada vez mais é comum se deparar com um apanhado de informações, muitas vezes genéricas e sem relevância, acerca da vida pessoal do acusado do que propriamente um estudo.

\footnotetext{
${ }^{259}$ Nesse contexto, é que o Conselho Federal de Psicologia passou a editar resolução a fim de regulamentar o exercício do profissional de psicologia nos estabelecimentos prisionais.

${ }^{260}$ CARMEN SILVIA DE MORAES BARROS, As modificações... cit., p. 188.

${ }^{261}$ JADER MARQUES, Exame de classificação e de observação criminológica na execução penal, in Ensaios penais em homenagem ao Professor Alberto Rufino Rodrigues de Sousa. Porto Alegre: Ricardo Lenz, 2003, p. 384.

${ }^{262}$ Alvino Augusto de SÁ, O exame criminológico... cit.,p.04.
} 
A crítica consiste no argumento de que laudos com conclusões vagas e imprecisas, nas quais são usados exatamente os mesmos termos por diferentes peritos, em diferentes casos e para diferentes presos. A verificação de que os termos são empregados de maneira abstrata, demonstram que os exames criminológicos foram feitos apenas de modo protocolar para se referir à generalidade dos presos.

Verifica-se que os exames estão perdendo o foco, sendo feitos sem um propósito definido, de maneira cada vez mais invasiva, considerando a vasta gama de perguntas aleatórias, e muitas vezes despropositadas, que são feitas ao sentenciado (suas enfermidades de infância; data de sua primeira experiência sexual; se tem pais vivos e se é ou não primogênito em sua casa; se repetiu a segunda série do primeiro grau, porque a repetiu e como eram suas relações com sua professora; se tem tipo físico atlético ou tatuagem no ombro esquerdo e assim por diante.). ${ }^{263}$

Não bastasse esses questionários despropositados, os laudos se revestem de juízos morais negativos, tendem a ser estigmatizantes e recheados de expressões vagas, abertas a múltiplas interpretações, revelando alto grau de subjetivismo. Não é incomum se deparar com expressões como imaturidade e infantilidade nos exames criminológicos, que não são conceitos científicos.

As conclusões dos laudos são permeadas pelas seguintes expressões: pouco senso de responsabilidade, ausência de arrependimento ${ }^{264}$ pelo que fez e intenção de não voltar mais a delinquir, personalidade imatura, com dificuldades em assimilar leis e regras, indicativas de persistência de periculosidade. Percebe-se que "de maneira geral, os técnicos trabalham com a ideia de que o ego do detento é capaz de "amadurecer" nas condições prisionais brasileiras, solicitando destes, amadurecimento e reflexão com a experiência de aprisionamento". ${ }^{265}$

O exame criminológico deveria verificar se o sentenciado reúne condições para retornar a sociedade, no entanto, nota-se que há expectativa que o sentenciado atinja um nível de evolução psicológica, sentimental, emotiva, em geral, inatingível pela maioria das pessoas. As exigências são tão rigorosas e descabidas, representando uma adequação,

\footnotetext{
${ }^{263}$ SÉRGIO MAZINA MARTins, A construção histórica... cit., p.225.

264 Anota SÉRGIO MAZINA MARTINS: "Vemos, na verdade, que a nuclearização do direito penal ao redor da alma é um movimento permanente que não apenas não acabou nas Inquisições (lembremos das torrentes de julgados paulistas que ainda hoje, insistem na importância da confissão do réu para comprovar seu arrependimento, ou que, também ainda hoje, insistem na importância da admissão da culpa perante o corpo técnico quando se trata de julgar o condenado merecedor ou não de uma progressão de regime prisional)[...]"(Idem, p.276).

${ }^{265}$ JULIO CÉSAR DinIZ HOENISCH, A Psicologia entre... cit., p.191.
} 
praticamente inatingível, do sujeito real em sujeito ideal, a ponto de Tribunal de Justiça paulista manifestar-se no sentido de que se trata de procedimento de progressão em regime prisional e não de processo canônico de beatificação. ${ }^{266}$

A esse respeito Eduardo Pereira Santos disserta que nos pedidos de promoção, os são laudos são "estereotipados, quase sem significado, de premissas tantas vezes contraditórias e distantes da conclusão. É comum serem vistas nesses laudos, a pretexto de sugerir a recusa ao benefício pleiteado, considerações que dizem respeito a todo gênero humano, debilidades e fraquezas próprias da condição humana, que eu, como julgador, busco superar na minha própria personalidade, como insegurança, carência afetiva, labilidade, medos". ${ }^{267}$

O Tribunal de Justiça de São Paulo reconhece que o fato de ser o reeducando detentor de certa imaturidade, um verdadeiro conceito indefinido, não poderá obstá-lo ao ganho do benefício penitencial objetivado. ${ }^{268}$

Por outro lado, também há decisões em que o Tribunal paulista cassou a progressão dada a sentenciado pelo Juízo das Execuções, pois, após diligência requerida pela Procuradoria Geral de Justiça consistente na submissão do encarcerado ao exame criminológico, ficou atestado no relatório social que "parece que sua vida delituosa se deve a uma imaturidade e inabilidade de perceber seus limites e lidar com frustrações”. Em avaliação psicológica, teve o seguinte prognóstico: “Denota ser uma pessoa tensa, com certa vulnerabilidade aos estímulos externos, dificultado lidar com suas frustrações.”. A

\footnotetext{
${ }^{266}$ Com relação a este tópico importante mencionar decisão dada no Agravo em Execução 692.859-6, Rel. Des. Corrêa de Moraes, pelo então Tribunal de Alçada Criminal de São Paulo que brilhantemente esmiúça a problemática dos laudos lacônicos, subjetivos e recheados de expressões vagas: "Alega-se que o agravado: apresenta 'baixa elaboração crítica; tem apenas vaga expectativa frente à realidade futura; exibe 'traços de imaturidade, insegurança, dependência materna e agressividade'. Ora, de indivíduo com instrução primária, não é razoável exigir elevado nível de elaboração crítica - seja isso lá o que for. Por igual, segurança e maturidade não são atributos que costumeiramente ornamentam indivíduos encarcerados e de 'baixo nível socioeconômico’. Também não era lícito esperar que um recluso manifestasse definidas e concretas expectativas quanto à realidade futura; aliás, quem, cá fora, pode, sem leviandade ou estultícia, descortinar no horizonte longínquo mais do que fugidias e diáfanas promessas? Se dependência materna fora razão bastante para que se mantenha alguém segregado, homem nenhum, com sua inexorável marca edipiana, poderá escapar a esse destino. Finalmente, traços de agressividade, em meio hostil e ameaçador, e de tão pequena intensidade que não excluem urbanidade e equilíbrio, devem ser considerados como imanentes características da imperfeita alma humana e, até mesmo, como evidência de saúde mental. Em síntese: tratase de procedimento de progressão em regime prisional e não de processo canônico de beatificação, significando dizer que não tem cabimento pretender exiba o reeducando qualidades reservadas a uns poucos escolhidos..."

${ }^{267}$ EDUARDO PEREIRA SANTOS. Execução Criminal... cit., p.111.

${ }^{268}$ TJSP, Agravo em Execução Penal no 993.08.014566-0, $7^{\text {a }}$ Câmara de Direito Criminal, Rel. Sydnei de Oliveira Jr., j. 26/06/2008.
} 
Câmara julgadora entendeu que diante de tais circunstâncias, inadequada a reinserção ao convívio social, pela ausência de mérito à concessão do benefício. ${ }^{269}$

O excesso de subjetivismo compromete a qualidade do laudo, uma vez que dificulta a parte contraditar a prova, retirando-lhe a força probante que advém de conclusões elaboradas com base em premissas verídicas e em raciocínio lógico, técnico e científico, tornando-o imprestável. ${ }^{270}$

\subsection{Necessidade da presença de médico psiquiatra}

Conforma já exposto, como a própria Lei de Execução Penal previu que na falta do Centro de Observação o exame criminológico poderá ser realizado pela Comissão Técnica de Classificação (CTC), por equiparação, admite-se que o exame seja instruído por peças confeccionadas pelas mesmas categorias profissionais componentes da CTC (chefes de serviço, psiquiatra, psicólogo e assistente social).

O psiquiatra deve fazer "o diagnóstico clínico do estado ou processo mórbido e a sua influência sobre a personalidade global, e salientar, especialmente, os traços patológicos que tenham sido determinantes do aparecimento do crime e, porventura, possam justificar um perigo de recidiva.". ${ }^{271}$

De artigo estrangeiro que aborda prova pericial psiquiátrica nos processos judiciais, debruçando-se mais especificamente acerca da inimputabilidade, é possível se extrair importantes noções e limites acerca da função do psiquiatra-perito, o qual "debe pronunciar un diagnóstico clínico e informar al Juez o Tribunal sobre las derivaciones de éste en la personalidad del enfermo, sin pretender, desde luego, arrogarse la decisión sobre si el sujeito al que há examinado, debe o no ser castigado" 272 , no caso do presente trabalho, ser progredido ou não de regime prisional.

O Tribunal de Justiça de São Paulo já apontou que a ausência do referido profissional prejudica a análise das condições subjetivas do sentenciado para a progressão de regime, uma vez que, em conjunto com os demais pareceres da comissão, poderá dar ao Juízo uma ideia mais detalhada a respeito do comportamento e das reações do reeducando

\footnotetext{
269 TJSP, Agravo em Execução no 993.07.057459-3, 16 ${ }^{\mathrm{a}}$ Câmara Criminal, Rel. Almeida Toledo, j. 23.06.2009.

${ }^{270}$ HUMBERTO THEODORO JÚNIOR, Admissibilidade da prova ... cit..p.70.

${ }^{271}$ VILSON FARIAS, $O$ exame criminológico ... cit..p 290.

272 JUAN-FELIPE HIGUERA GUIMERÁ, La prueba pericial ... cit., p.24.
} 
frente às mais variadas situações, notadamente, sobre eventual distúrbio ou doença, noção sobre a situação em que se encontra e prognóstico sobre sua vida. ${ }^{273}$

Existe entendimento jurisprudencial que a falta de parecer psiquiatra pode levar ao reconhecimento de nulidade do exame criminológico, na medida em que não foi elaborado pela CTC em sua composição integral tal qual determina a lei. ${ }^{274}$ Por outro lado, há entendimento de que essa nulidade seria relativa, considerando que não havendo questionamento acerca da higidez mental do sentenciado a ausência de psiquiatra na avaliação não invalidaria o trabalho dos demais profissionais. ${ }^{275}$

Com efeito, a presença do psiquiatra é muito importante, porém, o exame criminológico, não deve ser confundido com o exame psiquiátrico, pois, ao contrário deste, soma uma multiplicidade de interferências possíveis na vida de um ser humano. ${ }^{276}$

Na prática, tem se verificado que a avaliação do psiquiatra tem perdido prestígio, pois não tem passado de meros informes clínicos, não constituindo uma avaliação séria, sem a profundidade esperada para caracterizar uma prova com força pericial.

Para vulnerar ainda mais a exigência da presença de médico psiquiatra na elaboração do exame criminológico, o Supremo Tribunal Federal já se pronunciou no sentido de as avaliações psicossociais, isto é, as realizadas somente por assistente social e por psicólogo, estarem compreendidas no gênero "exame criminológico" e poderem servir de subsídio técnico para a formação da livre convicção do magistrado. ${ }^{277}$

Por derradeiro, deve-se considerar que diante das carências do sistema penitenciário, a falta do parecer de psiquiatra nos laudos periciais é frequente, no entanto, tal falha não pode ser levada em prejuízo do sentenciado.

A falta de avaliação psiquiátrica não deve obstaculizar o pleito, pois o sentenciado não pode ser punido pela desestruturação do aparelho estatal quanto à contratação de servidores aptos para realizar os exames periciais tal qual manda a legislação. Dessa forma, o condenado não pode ser prejudicado pela interpretação literal do artigo $7^{\circ}$, da LEP, ainda mais quando todos os demais elementos de convicção recomendam a concessão da progressão pretendida.

\footnotetext{
${ }^{273}$ TJSP, Agravo em Execução no 990.09.358209-0, $3^{\text {a }}$ Câmara Criminal, Rel. Ruy Alberto Leme Cavalheiro, j. 06/04/2010

${ }^{274}$ TACRIMSP, Agravo em execução 1.396.171/8,11 a Câmara criminal, Re. Des. Ricardo Dip, j. 24.11.2003; TJSP, Agravo em execução no 990.10.121707-4, $5^{\text {a }}$ Câmara, Rel. Pinheiro Franco, j. 29/07/2010; STJ, Resp $\mathrm{n}^{\circ}$ 636.271, Rel. Gilson Dipp, j.07/06/2005.

${ }^{275}$ STJ, Resp. n ${ }^{\circ}$ 619.950, Rel. Laurita Vaz, j.21/10/2004; STJ, Resp. no 623.032, Rel. Paulo Medina, j.31/05/2005.

${ }^{276}$ VILSON FARIAS, O exame criminológico ... cit.,p. 290.

277 STF, HC 94.503-1, $1^{\circ}$ Turma, Rel. Min Carmen Lucia, j.28/10/2008. RT 881/523.
} 


\subsection{Resoluções do Conselho Federal de Psicologia}

O tratamento psicológico no âmbito da execução penal é fundamental para garantir o ideal ressocializador da pena. Caberia à boa prática psicológica a proposição política de contribuir com a promoção dos direitos humanos, a clarificação sobre as vulnerabilidades sociais da população carcerária. O papel político do psicólogo no processo de execução penal é relevante e importante, uma vez, contudo, que os referenciais teóricos e epistemológicos se apresentem sólidos e éticos. ${ }^{278}$

Não bastasse a polêmica que envolve a dispensabilidade do médico psiquiatra para a confecção do exame criminológico, a elaboração de parecer pelo profissional da área de psicologia para instruir decisão judicial para fins de benefícios prisionais também foi alvo de discussão, o que culminou na edição de resoluções por parte do Conselho Federal de Psicologia com o intuito de regulamentar atuação psicólogo no sistema prisional.

Além de regulamentar a atuação do psicólogo no âmbito carcerário, buscava-se, na verdade, evitar que os pareceres psicológicos fossem utilizados como prova cabal da recuperação (ou não) do preso ou como atestados de probabilidade de reincidência, de modo a preservar a atividade do psicólogo, que não poderia ser responsabilizado pelo comportamento de um preso, que, depois de libertado, com base na avaliação psicológica, voltasse a cometer crimes.

Os psicólogos deveriam fornecer apenas pareceres opinativos, no entanto, seus relatórios passaram a ser interpretados de maneira taxativa e conclusiva para negar ou conceder os benefícios aos presos.

O Conselho Federal de Psicologia, ao editar essas resoluções, partiu da premissa de que houve um desvio de finalidade da função dos pareceres opinativos, além de óbvio contrassenso, pois sem trabalho psicológico algum oferecido no curso da execução das penas, não poderia o profissional prestar contas da responsabilidade ou do serviço que não realizou, qual seja, o acompanhamento psicológico. A elaboração dos laudos ou pareceres, nesses moldes, feria frontalmente os direitos dos presos e o exercício profissional do psicólogo.

${ }^{278}$ Julio CÉSAR DinIZ HoENISCH, A Psicologia entre ... cit., p.194. 


\subsubsection{Resolução nº 009/2010: Vedação ao psicólogo de realizar exame criminológico}

Em junho de 2010, o Conselho Federal de Psicologia editou a Resolução no 009/2010, fazendo considerações e regulamentando a atuação dos profissionais psicólogos dentro do sistema prisional, vedando, sob pena de falta disciplinar ética, a elaboração de laudos com opiniões acerca da possibilidade ou não de progressão do regime prisional.

A resolução é uma resposta aos laudos frutos de uma única entrevista, e que muitas vezes é o primeiro encontro entre o psicólogo e o detento, sendo improvável, nessas condições, o desenvolvimento de um trabalho de qualidade.

Exigir do psicólogo a elaboração de pareceres sobre quem, na maioria das vezes, nunca viu, e ainda cobrar acerto na avaliação psicológica, de maneira que ela apontasse a tendência do avaliado em reincidir na vida criminosa ou o perigo que ele representaria à sociedade, revelava-se uma tarefa árdua e praticamente impossível, pois se exigiria do psicólogo um verdadeiro exercício de "futurologia". Buscar-se-ia um atestado acerca da reincidência potencial, desconsiderando que a conduta reincidente decorre de um conjunto mais amplo, complexo e diversificado de fatores.

A psicologia é uma ciência que estuda o comportamento humano, que por sua vez é extremamente dinâmico e com diversas facetas. Desse modo, não se pode exigir de uma ciência humana, que acredita na mutabilidade de atitudes, apontamentos definitivos, com precisão matemática sobre a recuperação, diga-se, a adequação aos modelos sociais estabelecidos, de um indivíduo. ${ }^{279}$

Foi atentando para esse desvirtuamento do trabalho técnico do psicólogo, que a entidade de classe que os representava, considerando a prerrogativa que todo perito possui de recusar desenvolver laudos periciais, editou norma proibitiva sobre a participação dos psicólogos na elaboração dos exames criminológicos.

O psicólogo, na qualidade de perito, tem o direito, e até mesmo o dever, "de se escusar sempre que se considerar despreparado para bem desempenhar sua missão, por

\footnotetext{
${ }^{279}$ Com relação à dificuldade de quantificar o grau de credibilidade do conhecimento no âmbito das ciências humanas porque não há um cálculo estatístico disponível, MiCHELE TARUFFO aponta: "Basta pensare alla psicologia o all'antropologia per rendersi conto que già il linguaggio in cui questo scienze solitamente si esprimono è lontaníssimo dai parametri quantitativi ai quali si pensa quando si fa riferimento ala scienze “dure"."(Conoscenza scientifica e decisione giudiziaria: profili generali, Queaderni Della Rivista trimestrale di Diritto e procedura civile. Decisione giudiziaria e verità scientifica, Guiffrè, Milano, Nº8, 2005, p.21).
} 
carecer de conhecimento técnico ou científico necessários ${ }^{280}$,, ou subsídios para aplicar e desenvolver seu conhecimento especial, no caso concreto.

E mais, Ada Pellegrini Grinover leciona que "o experto é absolutamente livre para aceitar o múnus ou para recusá-lo. Por isso, se entender que não reúne conhecimentos suficientes para enfrentar a questão de fato - em toda sua especialidade e complexidade-, deve alertar o juízo para tanto; quer recusando a designação, quer expondo a necessidade de nomeação de outros peritos competentes para as áreas de conhecimento que não domina". 281

$\mathrm{O}$ artigo $4^{\mathrm{o}}$ da citada resolução veda ao psicólogo que atua nos estabelecimentos prisionais realizar exame criminológico, definindo não ser possível ao psicólogo realizar qualquer prática com fins de subsidiar decisão judicial durante a execução da pena do sentenciado. $^{282}$

A princípio, a resolução do Conselho Federal de Psicologia foi entendida como uma adequação da prática psicológica à legislação nacional, considerando a Lei $\mathrm{n}^{\mathrm{o}}$ 10.792/03 teria excluido a necessidade de parecer da Comissão Técnica de Classificação e do exame criminológico para motivar e preceder a decisão sobre benefícios legais analisados em incidentes de execução.

A resolução do Conselho Federal de Psicologia concretizava o que já vinha sendo notado na prática, isto é, que os exames criminológicos do modo como vinham e continuam a ser elaborados em nada contribuíam para o desenvolvimento de políticas de tratamento social e psicológico aos cativos com a finalidade de ajudá-los a restabelecer os laços sociais rompidos com a exclusão que não é somente física, mas também de ordem psicológica.

$\mathrm{Na}$ realidade o que se constatava (e ainda se constata) é que o acompanhamento psicológico sistemático e permanente, quase inexistente nas cadeias brasileiras, é substituído por entrevistas pontuais, encontros curtos e rápidos, dos quais resultam pareceres rasos e por vezes estigmatizados, derivados de mera rotulação, que serão utilizados para instruir a prolação de decisões judiciais.

\footnotetext{
280 ADA PELLEGRINI GRINOVER Prova pericial, ... cit..p6.

${ }^{281}$ Idem,.p. 9.

${ }^{282}$ Art. $4^{\circ}$. Em relação à elaboração de documentos escritos:

a) Conforme indicado nos Art. $6^{\circ}$ e $112^{\circ}$ da Lei $n^{\circ} 10.792 / 2003$ (que alterou a Lei $n^{\circ} 7.210 / 1984$ ), é vedado ao psicólogo que atua nos estabelecimentos prisionais realizar exame criminológico e participar de ações e/ou decisões que envolvam práticas de caráter punitivo e disciplinar, bem como documento escrito oriundo da avaliação psicológica com fins de subsidiar decisão judicial durante a execução da pena do sentenciado; (g.n.)
} 
Como não poderia deixar de ser a edição da Resolução no 009/10 do Conselho Federal de Psicologia divide opiniões.

Há quem considere a postura deste ente como corajosa e de vanguarda no trato das questões relacionadas ao sistema prisional, ${ }^{283}$ ressalvando-se que "a atuação do psicólogo no sistema prisional é de suma importância para a garantia da dignidade da população carcerária, mas não na condição de laudista ou de agente disciplinador, funções assumidas quando participa desse exame fajuto, mas, sim, como realçado na Resolução no 009/2010 do CFP, trabalhando no acompanhamento terapêutico do preso, buscando compreender os sujeitos na sua totalidade histórica, social, cultural, humana e emocional, na promoção da saúde mental, visando a criação ou o fortalecimento dos laços sociais e comunitários etc."284

Por outro lado, a mencionada resolução foi alvo de críticas por parte de alguns estudiosos, que afirmam ser equivocada a postura do Conselho Federal de Psicologia, primeiro porque os artigos $6^{\circ}$ e 112 da Lei de Execução Penal não proíbem a realização do exame criminológico, e segundo, porque não caberia ao referido Conselho impor a indevida, e talvez até inconstitucional, proibição ao exercício da profissão de psicólogo, especialmente no campo da execução penal, e menos ainda no momento e para as finalidades indicadas no corpo da resolução. ${ }^{285}$

A vedação imposta pela referida entidade de classe vai de encontro ao posicionamento dos Tribunais Superiores, que já sumularam a matéria a respeito da possibilidade de realização de exame criminológico.

Os problemas decorrentes da referida regulamentação não ficariam adstritos somente a qualidade do teor dos laudos, mas também refletiriam na prestação jurisdicional, pois havendo recusa do psicólogo incumbido, e isso com fundamento na referida resolução, estará criado impasse que demandará tempo para sua solução, com consequente demora na prestação jurisdicional e inevitáveis prejuízos ao executado e à sociedade. ${ }^{286}$

\footnotetext{
${ }^{283}$ HAROLDO CAETANO DA SILVA, O exame criminológico e a oportuna resolução no009/2010 do Conselho Federal de Psicologia, Revista Magister de Direito Penal e Processual Penal n.37 v.7,2010, p,39.

${ }^{284}$ Idem, p, 40.

${ }^{285}$ RENATO FLÁVIO MARCÃo, O exame criminológico e a equivocada resolução n ${ }^{\circ} 009 / 2010$ do Conselho Federal de Psicologia, Revista Magister de Direito Penal e Processual Penal n.37 v.7, 2010 p,37.

${ }^{286}$ Idem, p,38.
} 


\subsubsection{Suspensão dos efeitos da Resolução n ${ }^{\circ}$ 009/2010}

A Resolução $n^{\circ}$ 009/2010 foi vista com grande temor, principalmente pelo Ministério Público que vislumbrava maior prejuízo à qualidade dos laudos criminológicos, uma vez que estes seriam privados da opinião do profissional da área de psicologia, cuja contribuição é de suma relevância.

A vedação imposta ao psicólogo de participar da realização do exame criminológico mobilizou parte da comunidade jurídica a fim de cassar os efeitos da resolução ou reformular seus termos.

Nessa esteira, a Procuradoria da República no Rio Grande do Sul - Procuradoria Regional dos Direitos do Cidadão, requereu a suspensão da Resolução n ${ }^{\circ}$ 009/2010, sob pena do ajuizamento de ação civil pública para suspender os termos da referida Resolução.

Considerando este requerimento, o Conselho Federal de Psicologia, em setembro de 2010, editou a Resolução no 019/2010 que suspendeu os efeitos da Resolução nº 009/2010 por seis meses. Posteriormente, o Conselho Federal de Psicologia elaborou a Resolução $n^{\circ}$ 012/2011, a qual suspendeu os efeitos da Resolução nº 009/2010 até 02 de junho de 2011.

\subsubsection{Resolução 012/2011: o fim dos prognósticos psicológicos}

A Resolução 009/2010 do Conselho Federal de Psicologia gerou muita polêmica e justamente, por isso teve vida curta. Basta considerar que a citada resolução foi publicada em julho de 2010, mas logo em setembro do mesmo ano teve seus efeitos suspensos por seis meses, suspensão esta que foi prorrogada até 02 de junho de 2011 , data em que foi substituída pela Resolução 012/2011, sendo, portanto, revogada. Desse modo, verifica-se que a Resolução no 009/2010 apenas vigorou por cerca de um mês, tempo suficiente para causar alvoroço no mundo jurídico, fomentando a reflexão acerca do papel exercido pelo psicólogo na execução penal, principalmente na elaboração dos exames criminológicos para benefícios.

Se antes das resoluções do Conselho Federal de Psicologia os laudos psicológicos não deveriam ser encarados como diagnósticos absolutos (embora era isso que acontecia na prática), uma vez que não atingiam o juízo de certeza, mas mero juízo de probabilidade com relação a recuperação (ou não) do preso, dada a natureza humana da ciência da 
psicologia, após a Resolução 012/2011, nem mais poderão ser encarados como juízos de probabilidade.

Nos termos da Resolução 012/2011, o psicólogo pode apenas se manifestar sobre a possibilidade de reinserção do preso na sociedade, mas está proibido de elaborar parecer de prognóstico criminológico de reincidência e de aferir a periculosidade. ${ }^{287}$

Com efeito, atestar que o preso, se posto em liberdade, irá reincidir configura-se mera especulação, afinal o psicólogo não tem meios de prever o futuro. A psicologia, não é uma ciência exata, logo, não tem como elaborar cálculos e taxas de probabilidade sobre a ocorrência da reincidência. $\mathrm{O}$ mesmo se aplica à aferição da periculosidade. Não há como aplicar um critério matemático à periculosidade, sendo inviável mesurá-la.

Dessa forma, deve se empregar o conhecimento científico da psicologia no contexto da execução da pena, não para formular previsões, mas sim fornecer opiniões para direcionar a decisão judicial rumo ao acerto. A iniciativa estará voltada à busca e ao recolhimento de dados úteis para o melhor acertamento fático no que se refere a concessão ou não de benefícios na execução da pena, tomando por base a avaliação dada pelo psicólogo, sem tomar sua opinião como verdade absoluta, cotejando-a com outros elementos constantes nos autos, tais como atestado de conduta, boletim informativo, laudo psiquiátrico, parecer de assistente social, cabendo ao juiz analisar todas essas provas para decidir sobre a reinserção social do preso.

A Resolução nº 012/2011 ao permitir a participação do psicólogo na confecção dos exames criminológico, vedando a elaboração de previsões e juízos de probabilidade, visa encontrar o equilíbrio entre preservar a função do psicólogo, garantindo o respaldo à atividade profissional, e manter a valorosa contribuição desse técnico na composição dos laudos de modo a não abalar ainda mais a qualidade de seu teor.

287 Art. $4^{\circ}$ Em relação à elaboração de documentos escritos para subsidiar a decisão judicial na execução das penas e das medidas de segurança:

a) A produção de documentos escritos com a finalidade exposta no caput deste artigo não poderá ser realizada pela(o) psicóloga(o) que atua como profissional de referência para o acompanhamento da pessoa em cumprimento da pena ou medida de segurança, em quaisquer modalidades como atenção psicossocial, atenção à saúde integral, projetos de reintegração social, entre outros

b) A partir da decisão judicial fundamentada que determina a elaboração do exame criminológico ou outros documentos escritos com a finalidade de instruir processo de execução penal, excetuadas as situações previstas na alínea 'a', caberá à(ao) psicóloga(o) somente realizar a perícia psicológica, a partir dos quesitos elaborados pelo demandante e dentro dos parâmetros técnico-científicos e éticos da profissão. $\S 1^{\circ}$. Na perícia psicológica realizada no contexto da execução penal ficam vedadas a elaboração de prognóstico criminológico de reincidência, a aferição de periculosidade e o estabelecimento de nexo causal a partir do binômio delitodelinqüente.(g.n)

$\S 2^{\circ}$. Cabe à(ao) psicóloga(o) que atuará como perita(o) respeitar o direito ao contraditório da pessoa em cumprimento de pena ou medida de segurança. 
Outro ponto relevante da Resolução $n^{\circ}$ 012/2011 que merece ser mencionado refere-se a participação das partes na elaboração do laudo psicológico. Nos termos da resolução, a perícia psicológica somente será realizada a partir dos quesitos elaborados pelo demandante e dentro dos parâmetros técnicos-científicos e éticos da profissão. Garante-se assim a qualidade técnico-científica do laudo pericial, tornando-o mais objetivo, bem como assegurar maior imparcialidade do perito e evita que o psicólogo extrapole de suas competências, proferindo manifestações que não interessem às partes.

\subsection{Possibilidade das partes formularem quesitos aos peritos}

Existe divergência acerca da possibilidade das partes poderem formular quesitos a ser respondidos pelos peritos responsáveis pela confecção do exame criminológico.

Ao disciplinar a prova pericial, o Código de Processo Penal, em seu artigo 176, faculta às partes a apresentação de quesitos até o ato da diligência.

O exame criminológico representa espécie de perícia, e, em sendo assim, se submete no que couber às regras estabelecidas para esse meio de prova pelo Código de Processo Penal, o que nos leva a concluir que seria coerente permitir às partes a formulação de quesitos.

Quem tem entendimento contrário, aduz que embora o exame criminológico consista em parecer técnico destinado a auxiliar a formação da convicção do juiz da execução, fato é que é produzido extrajudicialmente e, sendo assim, não é necessário observar as formalidades do contraditório, sendo dispensável a formulação de quesitos antes da apresentação do laudo. Em complemento, argumenta-se também que o exame criminológico não poderia consistir em perícia propriamente dita, porquanto não realizada por peritos oficiais, cuja investidura decorre da lei ou quando nomeados pelo juiz mediante compromisso, não se aplicando, em caráter geral, o disposto no artigo 176 do Código de Processo Penal.

Há inclusive entendimento jurisprudencial no sentido de que as partes não podem formular quesitos em sede de exame criminológico, pois não há previsão legal para tanto, não havendo ofensa aos princípios da ampla defesa e do contraditório. ${ }^{288}$

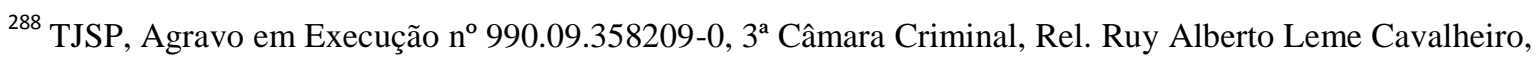
j. 06/04/2010.
} 
Guilherme de Souza Nucci afirma que "a participação da defesa técnica na elaboração do parecer da Comissão Técnica de Classificação e do exame criminológico é inviável, pois os profissionais que irão avaliar o condenado atuam dentro do presídio, com a inteira liberdade para emitir sua opinião técnica, a respeito do mérito do sentenciado. Isso não impede, no entanto, que, em juízo, apresentado o parecer e o exame, possa o defensor questionar o seu conteúdo e até requerer provas para complementá-lo ou anulá-lo.”289.

De relevo mencionar que José Frederico Marques, incumbido de elaborar estudos visando a reforma processual penal, no final da década de 60, apresentou o Anteprojeto de Modificação do Código de Processo Penal, no qual o exame criminológico foi inserido na seção de prova pericial, e o artigo 397 desse projeto previa que o exame criminológico seria realizado por peritos oficiais e que antes de ser o réu submetido ao exame, as partes e o juiz poderiam oferecer quesitos. ${ }^{290}$

Desse modo, fácil constatar que já houve a intenção em prever a possibilidade de oferta de quesitos pelas partes e pelo juiz. Atente-se ainda que o exame criminológico ficaria situado na seção prova pericial, sanando eventuais dúvidas acerca da sua natureza.

Para acender ainda mais a discussão, conforme já exposto acima, a Resolução do Conselho Federal de Psicologia $n^{\circ}$ 012/2011, que regulamenta a atuação do psicólogo no âmbito do sistema prisional, dispõe que o psicólogo somente poderá realizar a perícia psicológica a partir dos quesitos elaborados pelo demandante. De acordo com esta resolução as partes não só podem como devem elaborar quesitos. A elaboração de quesitos passa a ser condição para que o psicólogo possa elaborar o exame criminológico.

Nessa toada, a corrente que sustenta a inviabilidade da formulação de quesitos no exame criminológico sofre duro golpe, pois, considerando a nova resolução do Conselho Federal de Psicologia, a avaliação psicológica só poderá ser feita mediante a apresentação de quesitos ao psicólogo. Se as partes assim não agirem, o laudo psicológico não poderá ser a elaborado, sob pena de violação ética e infração disciplinar, e consequentemente, não comporá o exame criminológico.

Evidente que ao estipular que os quesitos devem ser elaborados pelo demandante, inclui às partes e o próprio juiz da execução. Interpretação muito restrita e equivocada seria entender o termo "demandante" como sendo somente a autoridade judicial que subscreve a requisição do exame criminológico.

\footnotetext{
${ }^{289}$ GUILHERME De SOUZA NuCCI, Manual de Processo... cit., p.976.

${ }^{290}$ DJALMA LÚCIO GABRIEL BARRETO, Instituição do exame ... cit., p. 61.
} 
O novo modelo de avaliação psicológica, que irá compor o exame criminológico, inaugurado pela Resolução $n^{\circ}$ 012/2010 do Conselho Federal de Psicologia não visa restringir o acesso à prova, mas sim incentivar uma maior participação dos sujeitos processuais, em um espírito de colaboração, norteando o trabalho do psicólogo. Em confirmação a este novo espírito, basta atentar que o $\S 2^{\circ}$ do artigo $4^{\circ}$ da citada norma prega que o psicólogo que atuará como perito deve respeitar o contraditório da pessoa em cumprimento de pena ou medida de segurança, deixando mais do que claro que está assegurada às partes a participação ativa na elaboração do laudo.

Permitir a participação das partes na elaboração dos quesitos para aferição do mérito para atingir os benefícios prisionais contribui para o conhecimento do método de como a prova será produzida.

Para a formulação de quesitos mais precisos e coerentes, a indicação de assistentes técnicos pelas partes seria uma importante ferramenta para questionar e apurar o procedimento probatório pericial.

Embora não pacificada a questão acerca da possibilidade das partes formularem quesitos antes da realização do exame criminológico, tampouco a indicação de assistentes técnicos, o fato é que existe a possibilidade do juiz e das partes solicitarem informações complementares aos peritos, ou esclarecimentos sobre o laudo, após sua confecção.

Considerando que o delinquente do momento do crime, com certeza não será o mesmo do instante do exame, pois sofreu transformações negativas ou positivas, nem sempre devidamente avaliadas, ${ }^{291}$ garantir às partes a possibilidade de, mesmo após a produção do exame criminológico, requer informações complementares aos peritos, ou esclarecimentos sobre o laudo, faz parte do direito à prova e permite que cada parte tente extrair da prova pericial a informação necessária compor e sustentar sua linha argumentativa.

Negar à acusação e à defesa o direito de se pronunciar sobre o laudo, ensejaria a invalidade da prova, por ofensa ao contraditório, ampla defesa e acusação. Evidentemente que a impugnação do laudo ou do pedido de sua complementação, feito pela parte, deve ser objeto de apreciação e deliberação do juiz, sob pena de invalidade, pelas mesmas razões. ${ }^{292}$

\footnotetext{
${ }^{291}$ Idem, p.88.

${ }^{292}$ Luís Fernando de Moraes MANZANO, Prova pericial... cit., p 83.
} 


\subsection{Direito de permanecer em silêncio ou de se recusar a submeter ao exame}

Para os peritos conseguirem elaborar o exame criminológico devem contar com espírito de cooperação do próprio sentenciado, o que torna a interação com o periciado condição preciosa para a confecção de um laudo de qualidade. Quanto mais informações o perito tiver ao seu dispor, maiores serão as chances do acertamento fático perseguido pela perícia.

Todavia, considerando o presidiário como sujeito de direitos e o exame criminológico como prova pericial, cuja produção deve observar o devido processo legal, indaga-se sobre a possibilidade de permitir ao sentenciado que permaneça em silêncio durante sua elaboração, de ser avisado dessa possibilidade no início da entrevista, ou de se recusar a participar da elaboração do exame.

Ao se submeter ao exame criminológico, perícia interdisciplinar, o sentenciado estaria revelando aspectos muito peculiares de si, partilhando seus aspectos sociais, convívio familiar, psicológicos e psiquiátricos. Assim, partindo da premissa que o direito à intimidade é absoluto e indisponível, plenamente estaria justificada a atitude de quem se recusasse ao exame. ${ }^{293}$

Exigir que o sentenciado se pronuncie pode implicar a revelação de segredos até então muitas vezes adormecidos o que poderia trazer consequências ao réu e seus familiares, em nível superior às próprias naturais sequelas da prática do delito. ${ }^{294}$

Há inclusive quem defenda a impossibilidade da realização do exame criminológico com vistas fundamentar a concessão ou negação de direitos na execução penal, pois os profissionais que integram as equipes de observação criminológica ou a Comissão Técnica de Classificação não poderiam revelar aquilo que lhes é confidenciado pelo paciente. Nesse sentido, o psicólogo, por exemplo, tem o dever de manter o sigilo profissional a respeito de tudo que ouve, vê ou de que tem conhecimento em razão de sua atividade. ${ }^{295}$

Assim, somadas às razões éticas, afastar a submissão obrigatória do apenado às equipes de observação encontraria respaldo em base constitucional, uma vez que é devido o respeito à integridade moral do apenado, sendo invioláveis a intimidade, a vida privada, a honra e a imagem das pessoas.

\footnotetext{
293 DJALMA LÚCIO GABRIEL BARRETO, Instituição do exame... cit., p.54.

${ }^{294}$ Idem,p.55.

${ }^{295}$ JADER MARQUES, Exame de classificação... cit., p. 377.
} 
O exame criminológico não pode consistir em uma investigação da intimidade do condenado, mas tão-somente a coleta de informações necessárias, respeitada a autonomia da sua vontade ${ }^{296}$, para que seja possível ao magistrado formar um juízo sobre a conveniência de transferir o sentenciado a um regime menos gravoso.

Segundo Aury Lopes Junior, o princípio do nemo tenetur se detegere, estende-se ao processo de execução penal, e "o preso não pode ser compelido a declarar ou mesmo participar de qualquer atividade que possa incriminá-lo ou prejudicar sua defesa. Não pode ser compelido a participar de acareações, reconstituições, fornecer material para a realização de exames periciais (exame de sangue, DNA, escrita, etc) etc." ${ }^{297}$

Nessa esteira, o sentenciado deve ser avisado no início da entrevista acerca do seu direito de permanecer calado, direito expresso no inciso LXIII do artigo $5^{\circ}$ da Constituição Federal.

O exame criminológico geralmente é determinado pelo juiz, quando este se encontra diante da incerteza sobre o mérito do sentenciado, fato relevante para o julgamento da pretensão deduzida no pedido de benefícios da execução.

Se o sentenciado optar por ficar calado, haverá mitigação da prova para comprovação do preenchimento do requisito subjetivo. Nesse caso, será necessária a fixação de uma regra de julgamento para orientar o magistrado como decidir acerca da concessão de benefícios quando não tenha provas suficientes para formar seu convencimento.

Aparentemente a solução estaria fundada na regra do ônus da prova, segundo a qual incumbe a quem apresenta uma pretensão provar os fatos para a obtenção dos efeitos almejados. Será no momento de tomar a decisão que o magistrado irá se atentar as regras legais de distribuição do ônus da prova, quando então, ao verificar que determinado fato relevante para formar sua convicção não foi esclarecido, deverá imputar a uma das partes as consequências desfavoráveis da falta de prova daquele fato.

Há quem defenda que o silêncio do sentenciado não pode ser utilizado em seu desfavor. Nessa linha, a submissão do preso ao exame criminológico depende de sua intenção de falar ou de calar, não podendo ter negado qualquer direito em face de sua decisão de não se submeter à avaliação. ${ }^{298}$

\footnotetext{
${ }^{296}$ FABIANA LEMES ZAMALlOA PRADO, Execução penal... cit, p. 07.

${ }^{297}$ AURY LOPES Junior, Revisitando o Processo... cit., p. 387.

298 JADER MARQUES, Exame de classificação... cit, p. 380.
} 
O ponto vulnerável dessa corrente encontra-se no entendimento de que na execução penal, cuja finalidade é efetivar o título condenatório, já transitado em julgado, não incidiria presunção de inocência, portanto, não é aplicável o in dubio pro reo ${ }^{299}$. Dessa feita se o sentenciado calar ou negar-se a fazer o exame criminológico, a ausência de prova não beneficiaria o condenado.

Em contraponto, acenam os defensores daquela corrente que ainda que se admitisse que a falta do exame criminológico dificulte a dirimir as dúvidas do magistrado quanto a conveniência da concessão dos benefícios, essa incerteza não deve ser utilizada em desfavor do sentenciado, não podendo servir de pretexto para indeferir suas pretensões, mas deve ser relevada pelo juiz da execução, uma vez que a legislação deu instrumentos ao magistrado para reparar possível equívoco na concessão de progressão ou livramento condicional, tais como os institutos da regressão de regime de cumprimento de pena e da suspensão cautelar ou da revogação do livramento condicional. ${ }^{300}$

A possibilidade de guardar silêncio e da recusa do sentenciado em se submeter ao exame também pode ser analisada sob a questão do interesse.

Consoante já exposto, exercer o ônus da prova visa conduzir seu titular a uma condição mais favorável. Quem tem interesse em obter o pedido deve demonstrar a verdade do fato alegado em seu interesse, o qual se apresenta como relevante para o julgamento da pretensão deduzida, de forma que, não o fazendo, corre o risco de não obter vantagem que adviria de sua atuação e arcará com o prejuízo decorrente de sua inércia. Dessa forma, o maior interessado em que o juiz se convença da veracidade de um fato é quem deve se incumbir do ônus probatório.

No caso do pedido de progressão de regime e livramento condicional toma-se como o principal interessado o próprio executado, devendo ele demonstrar, por meio de provas, preencher os requisitos legais. ${ }^{301}$

A alegação de que o sentenciado é o principal interessado na concessão do benefício esbarra na noção de que ao Estado também interessa reintegrar de maneira

\footnotetext{
299 Seria o mesmo raciocínio aplicado à revisão criminal, hipótese na qual não vigora o in dubio pro reo, admitindo-se a existência de um ônus da prova subjetivo para o acusado.

${ }^{300}$ AlEXANDRE ORSI NeTTO, A falácia ... cit., p. 14-15.

${ }^{301}$ Nesse sentido, transcreve-se trecho do Agravo em Execução no 0204912-47.2009.8.26.0000, julgado em 12/04/2012, pela 6 ${ }^{a}$ Câmara de Direito Criminal Tribunal de Justiça de São Paulo, sob Relatoria do Desembargador José Raul Gavião de Almeida: "Repita-se, ao preso, a quem o título executivo reconheceu adequação ao regime fechado pela conduta praticada, incumbe o ônus de demonstrar que efetivamente mudou, estando em grado de alcançar o benefício do livramento condicional. Sem que satisfaça esse imperativo do próprio interesse não será possível a concessão do benefício. Na mesma esteira, TJSP, Agravo em Execução no 990.09.328939-3, 6ª Câmara de Direito Criminal, Rel.Des. José Raul Gavião de Almeida, j. 08/03/2012.
} 
adequada e segura os condenados. Portanto, o ônus da prova não seria exclusivo do sentenciado, já que se o ônus da prova incumbe a que alega, é preciso ter em mente que os incidentes execução podem ser abertos à pedido do Ministério Público que tem como uma das funções impulsionar esses expedientes, ou por ordem do magistrado que também deve zelar pelo correto cumprimento da pena. Nesses termos, o ônus da prova é de quem der ensejo a abertura do incidente e afirmar estarem preenchidos os requisitos.

$\mathrm{Na}$ maioria das vezes nos expedientes abertos a pedido do Ministério Público ou mediante determinação judicial não se encontra propriamente uma alegação de que o sentenciado faz jus ao benefício, mas sim um pedido ou uma ordem para se apurar o preenchimento das condições. Já nos expedientes promovidos pelo próprio sentenciado ou pelo seu defensor é mais corriqueiro se deparar com a afirmação de que o condenado preenche o lapso temporal (requisito objetivo) e tem mérito (requisito subjetivo), sendo mais natural, afirmar que o ônus da prova compete ao sentenciado nesses casos.

Esclareça-se que o atendimento ao ônus da prova não chega a ser condição de vitória, mas enfraquece a posição daquele que, em juízo, não o exercitou. ${ }^{302}$

Determinado o exame criminológico para aferição do requisito subjetivo com a finalidade de dirimir as dúvidas do magistrado com relação a este ponto, é esperado que o do sentenciado colabore com a prova, caso contrário, menores serão as chances de ter seu benefício concedido.

Evidente, que não se obriga o sentenciado a participar do exame, mas caso o preso opte por não falar, o seu silêncio poderá ser usado em seu prejuízo ${ }^{303}$, pois suprimida estará uma das provas entendidas como necessárias pelo Juízo para a apreciação de benefício.

Registre-se, contudo, que ante a persuasão racional, o juiz não poderá indeferir o benefício exclusivamente pela falta do exame. O exame só seria mais um elemento de convicção a ser utilizado pelo juiz para a comprovação do mérito. Em caso de recusa do sentenciado em participar da perícia criminológica, deverá o juiz se ater às demais provas constantes nos autos para analisar o pedido de progressão ou livramento condicional.

\footnotetext{
${ }^{302}$ PEDRO HENRIQUe TÁVORA NIESS, O ônus da prova no processo civil e no processo penal, Justitia, v.118, set./out. 1982, p. 194.

${ }^{303}$ AURY LOPES JUNIOR discorda do uso do silêncio em prejuízo do apenado, porém, admite que, na prática, isso acontece, e, fazendo alusão a alguns termos geralmente encontrados em exames criminológicos, registra que o apenado que não colabora é visto pelos técnicos como indisciplinado, perigoso, "reticente em aceitar ajuda". (A (im)prestabilidade jurídica dos laudos técnicos na execução penal, Boletim IBCCrim v.10, n.123, fev. 2003,p.12.).
} 
Destarte, é possível deferir o direito à progressão de regime, ao livramento condicional ou qualquer outro direito independentemente de exame, mesmo quando o apenado decidir não participar do exame. ${ }^{304}$

No entanto, esse argumento é bem pueril, pois como já visto, o exame criminológico só poderá ser exigido mediante decisão fundamentada. Ora se o magistrado determinou a realização do exame criminológico é porque não restou convencido, nem seguro para tomar sua decisão com base nas provas já constantes nos autos, como por exemplo, atestado de conduta, prontuário de faltas graves, trabalho, etc. Dessa forma, o magistrado já elegeu o exame criminológico como prova necessária para direcionar seu entendimento. Caso ele não seja feito por falta de colaboração do preso, parece lógico saber qual será o veredicto.

Desse modo, embora não se negue o direito ao silêncio ou de recusa na submissão do exame criminológico ao preso, na prática, essa é uma das situações em que o silêncio do condenado poderá lhe prejudicar, uma vez que ele impede a confecção de uma prova já elegida pelo magistrado como importante para o seu convencimento, não vigendo na execução pena o in dubio pro reo.

2. Adstrição do juiz à conclusão do exame criminológico e ao atestado de conduta emitido pela autoridade penitenciária

O Código de Processo Penal em seu artigo 182 dispõe que o juiz não ficará adstrito ao laudo, podendo aceitá-lo ou rejeitá-lo, no todo ou em parte. Em igual direção e complementando a ideia, o artigo 436 do Código de Processo Civil versa que o juiz não está adstrito ao laudo pericial, podendo formar a sua convicção com outros elementos ou fatos provados nos autos.

Os laudos periciais possuem caráter meramente opinativo ${ }^{305}$, podendo o juiz formar a sua convicção com outros elementos ou fatos provados nos autos.

O exame criminológico ou o atestado de bom comportamento são apenas um dos meios de prova a ser utilizado para a formação de convencimento do juiz, podendo ser rejeitado pelo julgador, caso este não vislumbre coerência com os demais elementos probatórios dos autos.

\footnotetext{
${ }^{304}$ JADER MARQUES, Exame de classificação ... cit, p. 379.

${ }^{305}$ JUTACRIM 24/31
} 
Diante da nova sistemática instaurada após a Lei $\mathrm{n}^{\circ} 10.792 / 03$, o exame criminológico não é mais obrigatório para atestar o mérito, bastando o atestado de conduta emitido pelo diretor do presídio. O atestado de conduta é prova que será sempre presente no incidente execução, ao passo que o exame criminológico só será realizado, mediante ordem judicial fundamentada.

Não estar adstrito à peça técnica, não significa que o trabalho dos peritos deva ser desprezado. Assim, determinar a confecção do exame criminológico evidentemente que não atrela o juiz a sua conclusão, no entanto, justamente por tê-lo considerado uma prova essencial para o deslinde da questão, o magistrado deve apreciar seus teor, sob pena de ensejar nulidade. Aclarando, Paulo Sergio Xavier de Souza explica que no que diz respeito à vinculação do magistrado aos exames que, inegavelmente, são detentores de discricionariedade condicionada à necessária motivação e não se vinculam aos laudos por força do sistema liberatório, pode-se dizer que, sendo o Exame Criminológico e o parecer da Comissão Técnica de Classificação, perícias médico-psiquiátricas de inegável valor probatório, a sua não consideração pelo magistrado tornaria nulo o procedimento, em situação semelhante ao que ocorre no processo penal. ${ }^{306}$

O simples fato de o exame criminológico ser favorável ou de o preso ostentar boa conduta, por si só, não pode ser encarado como um comprovante seguro e convincente para que se possa conceder a progressão de regime. O mesmo se aplica ao raciocínio inverso, ou seja, para indeferir benefícios quando o exame criminológico for desfavorável ou atestado indicar má conduta. ${ }^{307}$

A consideração isolada do exame criminológico ou do atestado de conduta, em termos de garantia de condições satisfatórias do encarcerado para obtenção de benefícios, pode não ser o suficiente para a tomada de decisões coerentes e justas.

Caso o juiz não concorde com a conclusão do exame criminológico ou do atestado de conduta exarado pelo diretor da prisão, deve esclarecer quais os motivos que o levaram a desacreditar tal prova, reportando-se ao conjunto probatório constante nos autos.

\footnotetext{
${ }^{306}$ PAUlo Sergio XAVIER DE SOUZA. A vinculação do juiz... cit.,p.281.

${ }^{307}$ Com o objetivo de comprovar empiricamente o aproveitamento ideológico dos laudos criminológicos realizados, ALESSANDRA TEIXEIRA menciona que em pesquisa realizada por ela juntamente com Eliana B.T. Bordini, publicada no artigo "Decisões Judiciais da Vara das Execuções Criminais: Punindo Sempre mais" In: São Paulo em Perspectiva, vol.18, $\mathrm{n}^{\circ}$ 1, jan-mar d e 2004, constatou-se que quando o parecer dos exames criminológicos era desfavorável, em $87 \%$ as decisões o acompanhavam indeferindo o benefício; já quando ocorria o contrário e o resultado era favorável ao preso, apenas $45 \%$ das decisões concediam o beneficio acolhendo o laudo. (Do sujeito... cit., p.104)
} 
O ideal é que o juiz não leve em conta unicamente a conclusão do laudo pericial ou do atestado, mas examine todo histórico do sentenciado no cumprimento da pena, compreendendo a conclusão de laudo dentro de um contexto mais amplo, para ter uma avaliação mais polivalente e mais segura para orientá-lo a melhor decidir.

Ainda que o laudo tenha conclusão favorável, o magistrado pode indeferir o benefício pleiteado, porém como não tem conhecimentos técnicos para contrariar os laudos, o magistrado deverá procurar nos autos motivos que justifiquem seu indeferimento, por exemplo, execução conturbada, registro de várias faltas disciplinares no prontuário do apenado. Em caso de parecer desfavorável, o raciocínio é o mesmo, isto é, o magistrado poderá deferir o benefício se entender recomendável considerando outros dados da execução, tais como se o sentenciado trabalha, se estuda, se retorna das saídas temporárias, etc.

Portanto, o juiz não está vinculado às conclusões dos laudos periciais ou do atestado de conduta, porém, ele também não pode decidir contrariamente a prova dos autos, afinal o livre convencimento não é discricionário. Assim, o juiz pode concordar ou discordar da perícia ou do atestado, desde que motive sua concordância ou discordância.

Enquanto o atestado de conduta é prova documental, o exame criminológico é prova pericial, e tendo em vista que se cuida de manifestação elaborada por especialistas, o dever do magistrado de explicar racionalmente como e por que decidiu pela acolhida ou rejeição do laudo exige uma argumentação mais apurada.

A situação é mais difícil no caso de rejeição do exame criminológico, considerando que o juiz não dispõe de conhecimentos técnicos especializados, pois caso os tivesse e lhe fosse possível chegar às próprias conclusões, a prova pericial seria desnecessária.

Justamente por trazer elementos técnicos importantes de avaliação da conduta, o exame criminológico que só deve ser afastado se circunstâncias concretas demonstrarem condições pessoais do sentenciado em dissonância com as conclusões dos peritos.

Por não haver na execução o contato direto do magistrado com o acusado, que muitas vezes julga sem sequer visualizar, falar com o acusado, em detrimento ao princípio da imediação, os resultados dos exames criminológicos são frios e, por conseguinte muito difíceis de ser analisados pelo magistrado.

Quando o laudo for contraditório ou não fornecer elementos suficientes para formar a convicção judicial, o juiz poderá de ofício ou a requerimento das partes, determinar nova 
perícia. A nova perícia não necessariamente substituirá a anterior, ela poderá ser complementar.

Evidente que, ante o princípio do livre convencimento, o magistrado não é obrigado a determinar a perícia, uma vez que esta não é exigência legal indeclinável, nem tampouco está vinculado às conclusões dos laudos periciais. Contudo, não se pode negar a importante ferramenta que a perícia consiste para aconselhar o julgador a tomar uma decisão mais consciente e segura.

Em endosso, Sidnei Agostinho Beneti leciona que "o exame criminológico não é determinante da decisão, porque esta, no contexto geral das provas e à incidência da livre convicção do Juízo, motivada com dados existentes nos autos, pode orientar-se em sentido diverso. Mas é irrecusável que os exames pesam muito na formação da convicção do julgador.". 308

Embora o magistrado não se vincule ao exame criminológico, deverá expor os motivos pelos quais o rejeitou e apontar as outras provas que lhe pareceram mais convincentes. Sua decisão deve ficar estritamente vinculada à prévia motivação que é sempre necessária, tratando-se de atos decisórios praticados pelo Poder Judiciário. Daí, falar-se em princípio do livre convencimento motivado." ${ }^{309}$.

\section{Valoração do laudo pelo juiz}

No ordenamento jurídico brasileiro, as decisões judiciais são tomadas com base no sistema do livre convencimento motivado, também denominado persuasão racional, no qual, o juiz tem liberdade para valorar as provas que utilizará para formar sua convicção, mas essa valoração deve ser explicada de maneira fundamentada e racional, ficando patente o exame crítico da prova.

Trata-se de uma liberdade pautada por critérios, devendo o juiz tomar como parâmetro as normas constitucionais, as leis, a doutrina, a jurisprudência, os costumes, os princípios gerais do direito, a equidade, as máximas da experiência ${ }^{310}$ e, é claro, o acervo probatório dos autos. Essa liberdade não pode ser confundida com arbitrariedade, uma vez

\footnotetext{
${ }^{308}$ SIDNEI AgOSTINHO BENETI, Execução penal... cit., p.133.

${ }^{309}$ PAUlO SERGIO XAVIER DE SoUZA, A vinculação do juiz... cit.. p. 277.

${ }^{310}$ UADI LAMMÊGO BULOS, O livre convencimento do juiz e as garantias constitucionais do processo penal, Revista da EMERJ v.3.n.12, 2000, p.196.
} 
que toda decisão deve ser pautada por raciocínio empiricamente comprovável e, portanto, passível de impugnação pela parte que da decisão discordar.

O processo de execução da pena deve ser desenvolvido de acordo com os princípios do devido processo legal. Nessa esteira, embora não expressamente referida pela Lei de Execução Penal ${ }^{311}$, a motivação de todas as decisões do juiz da execução é exigência que decorre do texto constitucional (art.93, IX, CF). Do mesmo modo que na sentença condenatória deve o juiz indicar os motivos que levaram à fixação do quantum da pena e de sua forma de cumprimento, as alterações subsequentes adotadas no juízo da execução devem resultar de decisão fundamentada. ${ }^{312}$

Diferente do sistema da prova tarifada, no qual as provas têm valores pré-fixados na lei, no sistema do livre convencimento motivado não há a preponderância de um meio de prova sobre o outro.

O exame criminológico foi idealizado como uma importante ferramenta para o magistrado formar a sua convicção acerca do merecimento do presidiário, e assim garantir maior acerto em sua decisão.

Antes da modificação introduzida pela Lei $n^{\circ} 10.792 / 03$, vislumbrava- se a exigência do exame criminológico para comprovação do requisito subjetivo para fins de progressão como sendo uma prova tarifada. Afinal o julgador estava atrelado aos critérios do legislador, em clara restrição à liberdade do juiz, que não poderia decidir o incidente de execução sem determinar a confecção do exame criminológico.

Atento a esta realidade, Salo de Carvalho expõe criticamente que "os laudos e pareceres criminológicos que ingressavam no processo de execução penal como prova pericial adquiriram, no passar dos anos, tamanha importância que acabaram (re)criando o sistema de prova tarifada, a qual, embora não vinculasse a decisão do juiz por força da adoção do sistema do livre convencimento motivado, instituía armadilha intransponível, mormente nos casos de pareceres desfavoráveis. Outrossim, por força de ser juízo empiricamente indemonstrável ("possibilidade de vir a cometer delito no futuro"), as perícias obstacularizam o direito ao contraditório, maculando o devido processo legal.",313

Eleger o exame criminológico como uma prova essencial de que o sentenciado que, outrora demonstrou inadequação para viver no seio social, não mais reincidirá, pois

\footnotetext{
${ }^{311}$ Há singela disposição sobre a motivação das decisões no art. 59, parágrafo único, da LEP.

312 AdA PEllegrini Grinover, Antonio Magalhães Gomes FilHo e Antonio ScARANCE Fernandes, $A$ exigência... cit., p.4

${ }^{313}$ Salo De Carvalho, $O$ (novo) Papel... cit., p. 166.
} 
assimilou a terapêutica penal, através da demonstração inequívoca do fím de sua periculosidade, para só então promovê-lo à liberdade gradual, representava, na realidade o prestígio destinado à técnica criminológica, introduzindo-se o discurso da 'verdade' no processo de execução, reeditando um sistema de prova tarifada, típico dos sistemas inquisitivos pré-modernos, que incapacita as normas de garantia, visto obstruir contraprova (irrefutabilidade das hipóteses). ${ }^{314}$

No entanto, os exames criminológicos não devem ser encarados como diagnósticos absolutos, pois não atingem o juízo de certeza, mas mero juízo de probabilidade, isto é, “o sujeito cognoscente não está convencido de estar em poder da verdade, mas estima ter se aproximado de um resultado". 315

Para aferir o mérito do sentenciado por meio do exame criminológico, o julgador deve contar com o auxílio de peritos, e levando-se em conta ser o exame criminológico uma perícia complexa, ou seja, que abrange várias áreas do conhecimento que, em sua maioria, escapam ao domínio do juiz, a interação entre o perito e o julgador é de grande relevância para a tomada de uma decisão mais justa, afinal "el Juez o Tribunal debe tener toda la información posible para dictar sentencia, ya que al no ser expertos, lógicamente, en Psiquiatría deben contar con asesores que les instuyan e ilustren sobre esta materia que no tienen obligación de conecer en su plenitude.”316

Com efeito, o exame criminológico dá (ou teria que dar) ao magistrado maior segurança na aferição do requisito subjetivo, contudo, Sérgio de Morais Pitombo já alertava que é preciso não privilegiar em demasia o exame criminológico, pois consiste apenas em perícia, em meio de prova e sua avaliação caberá sempre ao juiz da execução, que é livre ao apreciá-lo. ${ }^{317}$

Para que seja dado o devido valor ao exame criminológico enquanto prova, é necessário que o magistrado entenda o laudo, logo, é de suma importância que o experto explique de maneira acessível ao leigo, no caso o juiz, quais foram os dados que direcionaram sua conclusão.

Dessa forma, fundamental a exposição dos motivos em que se baseou o experto para emitir sua opinião, sob pena de o laudo perder sua força argumentativa e o valor probante, uma vez que dificulta o trabalho do magistrado para compreender a prova.

\footnotetext{
${ }^{314}$ SAlo de CARVAlHo, O papel da... cit., p.149.

${ }^{315}$ Marcos AleXANDre CoElHo ZILli, A iniciativa instrutória ... cit., p. 116.

${ }^{316}$ JUAN-FELIPE HIGUERA GUIMERÁ, La prueba pericial... cit., p.25.

${ }^{317}$ SÉRGIO MARCOS DE MORAES PITOMBO, Os regimes de... cit., p.315.
} 
Compreender a prova é fundamental para a sua valoração. No caso de provas periciais como o exame criminológico essa valoração apresenta maior dificuldade, eis que "via de regra, o magistrado não possuiu elementos técnico-científicos suficientes para contrariar a conclusão dos "experts" que diariamente acompanham o detento em sua trajetória prisional, mediante avaliação técnica capacitada, e que possuem autoridade para concluir pela aptidão do sentenciado e sua responsabilidade em arcar com estágio mais avançado no cumprimento da pena ou, então, quanto à possibilidade de liberdade em razão do livramento condicional." 318

Diante da dificuldade de se entender o laudo pericial, a solução mais frequente é acolhê-lo nos exatos termos em que se apresenta. ${ }^{319}$ Assim, constata-se uma proliferação de decisões judiciais de mera aderência às conclusões do exame criminológico. O que era para ser um parecer para integrar a decisão, transforma-se na própria decisão.

Ocorre que o magistrado sente-se seguro em decidir de acordo com o exame criminológico, pois justamente por ser uma peça técnica, elaborada, em tese, com cientificidade, passa ser encarado como um diagnóstico absoluto e preciso, sem margem de erro, o que dispensaria o confronto com outros dados.

Além de afrontar o dever de motivação das decisões judiciais, o principal problema em se acolher o exame criminológico como uma prova irrestrita, nas palavras de Aury Lopes Junior, é a legitimação do reducionismo sócio biológico. Esclarece o doutrinador que o juiz ao ratificar os laudos criminológicos sem exarar qualquer raciocínio crítico a respeito instaura a ditadura do modelo clínico, no qual o discurso jurídico é substituído pelo discurso da psiquiatria, tornando a decisão impessoal, inverificável e impossível de ser contestada. ${ }^{320}$

Encampando a mesma posição, Miriam Krezinger A. Guindani aclara que uma das principais discrepâncias entre processo de execução e os preceitos constitucionais está na adoção de princípio inquisitivo conferido ao exame criminológico, que legitima o discurso da psiquiatria e o reducionismo sócio biológico de matriz etiológica, destruindo qualquer possibilidade de contraditório e a defesa do pensamento e da prática de ser diferente. ${ }^{321}$

\footnotetext{
318 PAUlo Sergio XAVIER De SoUZA, A vinculação do juiz, ... cit..283.

319 Nesse passo, AURY LOPES JUNIOR: "Não raramente encontramos laudos - acolhidos pelos juízes - que negam o direito pleiteado aduzindo que a "personalidade, possui atenção normovigil e nomotenaz, orientação auto e alopsíquica, afeto normomodulado", e outras pérolas que são absolutamente impossíveis de serem demonstradas e refutadas." (Revisitando o Processo... cit., p. 395).

${ }^{320}$ Idem, p. 395.

${ }^{321}$ MiRIAM KRENZINGER A. GUINDANI, Os (des)caminhos da avaliação criminológica, Revista de Estudos Criminais n.10, v.3, 2003 p.137.
} 
Dessa forma, limitando-se o juiz a acolher os laudos de maneira acrítica, há a perigosa fundição do modelo jurídico com o discurso da psiquiatria. E o perigo está no excesso de subjetivismo, pois o discurso jurídico é refutável, mas o da psiquiatria não. É o que se denomina de ditadura do modelo clínico, na qual a decisão punitiva passa a ser reflexo de um juízo que não é feito pelo juiz, mas pelo psicólogo ou psiquiatra. Existe uma pulverização da responsabilidade de decidir . ${ }^{322}$

Salo de Carvalho compartilha a opinião de que "o juiz da execução penal, desde a instituição dos postulados da criminologia clínico-administrativa, deixou de decidir, passando apenas a homologar laudos técnicos. Seu julgamento passa a ser informado por um conjunto de micro decisões (micro poderes) que sustentarão 'cientificamente' o ato decisório. Assim, perdida no emaranhado burocrático, a decisão torna-se impessoal, sendo inominável o sujeito prolator., 323

De fato, ao julgarem os pedidos de benefícios, na maioria das vezes os juízes utilizam-se da motivação referida, isto é, remetem-se à conclusão do laudo e a chancelam na íntegra, sem sequer citar dados do exame criminológico ou fatos da própria execução que corroboram ou não com o que ficou atestado pelo exame para melhor fundamentar a decisão.

Na reflexão de Andrei Zenkner Schmidt "esta situação revela, na verdade, um dos mais graves vícios da execução penal: a síndrome da abstinência hermenêutica. É muito frequente, nas execuções penais, que se profira decisão desfavorável a um direito do apenado com base num laudo completamente incongruente. Assim, argumentos como "nos termos do laudo de f., opino pelo indeferimento do pedido", ou "com base no laudo de f., indefiro o pedido", são comuns em sede de execução da pena, fazendo com que a carga decisória de todas as pretensões do apenado acabe recaindo, em suma, nas mãos dos peritos. Como uma decisão ou um parecer para contrariar um laudo pericial, terá de ser fundamentada, acaba-se, por preguiça ou comodismo, corroborando-se um argumento que, muitas vezes, sequer foi lido. ".324

Importante demarcar que o perito auxilia o juiz, orientando-o no exercício jurisdicional agregando conhecimento, mas não o substitui, afinal não há delegação da decisão ao experto, permanecendo o juiz como o peritus peritorum. Por tal razão, não é

\footnotetext{
${ }^{322}$ AURY LOPES JÚNIOR. A (im)prestabilidade jurídica... cit., p. 11-13.

${ }^{323}$ SAlo de CARVAlHo, O (novo) Papel... cit., p.164.

${ }^{324}$ ANDREI ZENKNER SCHMIDT, Hermenêutica na execução penal, Revista Brasileira de Ciências Criminais v.9.n.38, abr./jun. 2002, p.111.
} 
porque o juiz não domine determinada área do conhecimento, tendo necessitado de auxílio de peritos, que deva acolher integralmente o parecer pericial.

Utilizar singelamente a conclusão do laudo para embasar a decisão configura-se em um repasse de responsabilidade do juiz para os peritos.

Quando o juiz concede a progressão ao sentenciado e este volta a delinquir é muito comum a mídia tecer críticas contundentes a este magistrado. Com medo de ser alvo de críticas o magistrado acaba optando por pedir a confecção de laudos para balizar a sua decisão e, assim, de certa forma, não se ser o único responsável por uma decisão que possa demonstrar-se precipitada e equivocada. Caso aquele apenado realmente não se demonstre digno da promoção de regime ou da liberdade condicional e desonre as regras, o magistrado compartilhará ou repassará a responsabilidade aos peritos. ${ }^{325}$

A disseminação da responsabilidade de decidir também se aplica aos casos em que os juízes adotam os laudos como fundamento exclusivo das decisões negatórias, na qual a decisão passa a ser reflexo de um juízo que não é feito pelo juiz, mas pelos expertos.

A transferência de responsabilidade é geral, instaurando-se um verdadeiro ciclo, uma vez que os pesquisadores acadêmicos e alguns teóricos do Direito Penal garantista acusam o Poder Judiciário de agir de forma inconstitucional, ao fundamentar suas decisões em uma avaliação inquisitorial. Já o Poder Judiciário acusa o Poder Executivo (sistema penitenciário), quanto à fragilidade técnica e morosidade dos pareceres. Os gestores das unidades acusam os técnicos de incompetentes e descomprometidos. Os presos sentem-se injustiçados pela demora das avaliações e pela forma como são realizadas. Os técnicos sentem-se pressionados por todos os lados e, em sua maioria, vivenciam um drama éticoexistencial com prática da perícia, que incide na decisão sobre a vida de uma pessoa. ${ }^{326}$

A motivação das decisões no curso do processo executivo penal reveste-se de verdadeira garantia constitucional ao apenado, de forma a garantir-lhe o conhecimento dos critérios adotados pelo magistrado para ter decidido daquela maneira, para que, discordando da decisão possa questioná-la, em atenção ao contraditório e a ampla defesa, princípios estabelecidos pela Constituição Federal. Por tal razão, a motivação não se resume na indicação de motivos que possam explicar a decisão, mas consiste na explicação

\footnotetext{
${ }^{325}$ Nesse sentido, GEORGE LOPES LEITE desabafa: "Toda responsabilidade pela saída do cárcere, afinal, recai sobre os ombros do juiz. Ninguém se lembra de que, por trás de uma decisão, há pareceres da Comissão Técnica de Classificação do presídio, psicólogos, assistentes sociais e do próprio Promotor Público. Nada disso importa: só se sabe que o juiz liberou um assassino impiedoso que ceifou a vida de alguém."(O papel do juiz... cit., p.60).

${ }^{326}$ Miriam KrenZinger A. Guindani, A, Os (des)caminhos... cit.,p.137.
} 
de razões que justifiquem a solução encontrada, devendo a argumentação ser capaz de reproduzir o raciocínio decisório, de modo a possibilitar o seu efetivo controle pelas partes, pelos órgãos superiores e pelo público em geral. ${ }^{327}$

Deve-se parar de atribuir a qualidade de julgador ao perito, considerando que não é responsabilidade da perícia julgar, e sim esclarecer o juiz acerca de fatos, cuja elucidação dependa de conhecimento técnico-científico estranho à judicatura.

Evidente que os exames criminológicos devem ser apenas um dos elementos a ser considerado para o deferimento ou não de algum benefício, e não o único. A conclusão do laudo pericial deve ser cotejada com elementos concretos da execução, garantindo-se coerência.

Imagine-se um laudo que diga que o sentenciado não está apto para o retorno ao convívio social, porém em exame ao seu boletim informativo constata-se que o sentenciado nunca praticou falta disciplinar, trabalha, tem dias remidos, estuda, sempre retornou das saídas temporárias que lhe foram concedidas. Ora, evidente que há um descompasso entre a conclusão do laudo e os dados concretos da execução.

Incumbe, portanto, ao magistrado avaliar os dados trazidos pelo exame criminológico, cotejando-os com os demais dados constantes no processo de execução do sentenciado, procurando verificar se os elementos periciais encontram respaldo nas demais provas produzidas nos autos, no caso de execução penal, principalmente na prova documental (relatório de conduta, boletim informativo, folha de antecedentes), a fim de constatar se as conclusões dos expertos são dotadas de raciocínio, lógico, técnico e científico, sem margens de subjetivismo.

No que tange ao risco de a perícia se transmutar em um mero relato de opiniões pessoais, afastando-se de seu verdadeiro escopo que é a apuração de maneira técnica e, portanto, imparcial de fatos, Humberto Theodoro Júnior ressalva que "o laudo cuja conclusão não é fruto da apreciação técnica dos fatos, mas configura mera emissão de parecer subjetivo e gracioso do perito, não tem valor jurídico e deve ser desprezado. Isso porque o juiz não é um mero repetidor da opinião do perito, mas alguém que tem o dever de decidir segundo convencimento formado."328

Ao mesmo tempo que se reconhece que os exames criminológicos contribuem para a proliferação de decisões de mera aderência, a tentativa de eliminá-lo enquanto exigência

\footnotetext{
${ }^{327}$ Antonio Magalhães Gomes Filho, O livre convencimento do juiz no Projeto de Código de Processo Penal: primeiras anotações. Boletim IBCCrim n.200, jul.2009,p.08.

${ }^{328}$ HuMBERTO THEODORO JÚNIOR, Admissibilidade da prova... cit..p.70.
} 
legal para a instrução de benefícios desagradou a muitos, e continua-se a insistir na sua elaboração, considerando-o para garantir uma decisão com a devida motivação. Em princípio, a situação é de total incongruência.

Com a nova sistemática introduzida pela Lei $\mathrm{n}^{\mathrm{o}}$ 10.792/03, retirar o exame criminológico como requisito legal para a prolação de decisão acerca de direito do apenado à liberdade gradual demonstra-se um marco na atividade valorativa do juiz na execução penal.

No sistema anterior, em que vigia a obrigatoriedade do exame para todos os casos, na verdade se "psiquiatriza" a decisão do magistrado, delegando a motivação do ato decisório ao perito, que o realiza a partir de julgamentos morais sobre as opções e condições de vida do condenado, como estabelece um mecanismo de um (auto)reprodução da violência pelo reforço da identidade criminosa. ${ }^{329}$

Já a nova redação da Lei de Execução Penal não retira do juiz da execução a decisão sobre a progressão de regime de cumprimento de pena ou o livramento condicional e lhe atribui maior responsabilidade para analisar e colher elementos nos autos, ou junto à autoridade administrativa, quando entender necessário, para verificar a presença do requisito subjetivo.

Se antes o magistrado poderia fundamentar sua decisão apenas com o exame criminológico, hoje, com o entendimento jurisprudencial sobre a nova redação da Lei de Execução Penal, o exame criminológico só poderá ser requerido mediante decisão fundamentada, forçando o magistrado e demonstrar o processo de racionalização desenvolvido para não aceitar o atestado de conduta emitido pela autoridade administrativa como prova suficiente, para isso, o juiz terá que suscitar os eventos concretos da execução do sentenciado. Somente da análise da motivação é que se pode garantir que as decisões foram tomadas com base nos elementos apresentados nos autos.

Sensível ao problema que circunda a atividade de valoração dos laudos na execução penal, José Renato Nalini, afirma que "faz-se imprescindível enfatizar que nessa jurisdição singularíssima, ao juiz se impõe seja, efetivamente, senhor do laudo. Quanta vez o subjetivismo com que redigidos os pareceres da Comissão Técnica de Classificação não dá margem a que o juiz faça a sua opção aparentemente indistinta entre conceder ou negar o favor legal? O exame dessas peças técnicas há de ser meditado, analisado com serena

${ }^{329}$ SAlo de CARVAlHo, O papel da perícia... cit., p.144. 
acuidade. É todo o processo de regeneração do sentenciado que se encontra imerso na solução a se conferir a seu pleito." 330

Ser ou não ratificador da conclusão de exame criminológico depende do próprio magistrado. É necessário que ele se conscientize de que ele é, na expressão cunhada por Nalini, o senhor do laudo, portanto é ele quem deve avaliar essa prova com liberdade, sem sentir-se atrelado, ou mesmo dominado pelas opiniões dos peritos, que, em algumas vezes, se revelam confusas, ambíguas, ou impalpáveis, e quase nada esclarecem.

O sucesso do exame criminológico enquanto prova hábil para atestar o mérito do sentenciado dependerá, evidentemente, da qualidade desse laudo, que é o suporte material, mas também da formação humanística e critério valorativo do Juiz ${ }^{331}$, que é o suporte intelectual, para balizar uma decisão mais acertada e justa.

\footnotetext{
330 José Renato Nalini. Pode o juiz... cit., p.144.

${ }^{331}$ DJALMA LúCIO GABRIEL BARRETO, Instituição do exame... cit., p.109
} 


\section{CONCLUSÃO}

A crise do sistema penitenciário é uma das questões que mais preocupa a sociedade atual. A forma como a pena é executada é um fator relevante para a tranquilidade e a segurança da sociedade, portanto, o estudo da execução penal é primordial para auxiliar na propositura de soluções para o seu aprimoramento.

Evidente que algumas adequações e atualizações na legislação devem ser feitas a fim de se adaptar a Lei de Execução Penal, feita na década de 80, momento em que ainda não era possível conceber a complexa criminalidade atual e como isso afetou a dinâmica do sistema carcerário contemporâneo. Contudo, deve-se ter cautela com as reformas pontuais, corriqueiras no nosso ordenamento jurídico, sob pena de comprometer toda a coerência do sistema.

A Lei n ${ }^{\circ}$ 10.792/03 ao dar nova redação ao artigo 112, da Lei de Execução Penal, alterou significativamente a sistemática de progressividade da pena. O legislador optou pelo fim do exame criminológico como requisito legal à concessão de benefícios prisionais, sendo suficiente para a comprovação do requisito subjetivo o atestado de bom comportamento carcerário emitido pelo diretor do estabelecimento.

Interessante relacionar que ao mesmo tempo em que a Lei $\mathrm{n}^{\circ} 10.792 / 03$ altera a sistemática da concessão de benefícios legais no âmbito da execução, simplificando-a, também recrudesce a estrutura disciplinar carcerária ao instituir o Regime Disciplinar Diferenciado. Aparentemente as ideias registradas na lei parecem opostas, mas na verdade a Lei $\mathrm{n}^{\circ}$ 10.792/03 deve ser compreendida como uma parte de uma nova política criminal que se visava instaurar. Com a alteração legislativa, o administrador voltou a concentrar grande poder com relação à dinâmica prisional.

Embora a determinação pela realização do exame criminológico tenha diminuído após o advento da Lei $\mathrm{n}^{\circ} 10.792 / 03$, o fato é que o exame nunca deixou de fato de ser requisitado pelos magistrados. A insistência em demandar por esta prova pericial levou a jurisprudência pátria a se manifestar, consolidando o entendimento pela facultatividade de sua realização a critério do magistrado.

O afã pela produção de provas técnicas-científicas como garantia de precisão na busca da verdade implica, na execução penal, aceitar-se qualquer parecer elaborado por assistente social, psicólogo e psiquiatra como sendo exame criminológico. 
É lamentável que exame criminológico, exame de personalidade e parecer da Comissão Técnica de Classificação sejam, na prática, tratados como se sinônimos fossem e sintetizados na mesma avaliação, pois a interação entre eles é de enorme importância para o aprimoramento da individualização da execução orientada por critérios científicos e técnicos

A diferença fundamental entre os exames é que o exame criminológico é perícia, e os demais não. $\mathrm{O}$ exame criminológico auxilia o magistrado na tomada de decisão jurídica procurando fornecer-lhe elementos esclarecedores sobre determinado fato juridicamente relevante, enquanto as demais avaliações tornam mais claras quais são as possibilidades e as estratégicas de recuperação do preso.

A iniciativa de determinar o exame criminológico está voltada à busca e ao recolhimento de elementos úteis para o melhor acertamento fático no que tange ao mérito do sentenciado. O problema não é a determinação em si da realização do exame criminológico, mas sim a expectativa gerada, quando não exigida, de que o exame forneça a certeza de que o comportamento criminoso irá ou não se repetir.

Atribuir tamanha importância ao exame criminológico para embasar a decisão judicial, elegendo-o como instrumento introdutor do discurso da 'verdade' no processo de execução compromete a avaliação da prova.

Não se nega o fato de que o exame criminológico pode constituir um importante elemento técnico para auxiliar o magistrado na formação de sua convicção acerca do merecimento do presidiário, e assim garantir maior acerto na escolha das medidas a serem aplicadas no desenvolvimento do cumprimento da pena, porém não se pode perder de vista que ele consiste apenas em meio de prova e sua avaliação caberá sempre ao juiz da execução, que é livre ao apreciá-lo.

A exigência do exame criminológico para fundamentar a decisão judicial na verdade é uma via de mão dupla, pois, ao mesmo tempo em que se alega que os exames criminológicos são relevantes para garantir uma decisão com a devida motivação, percebese que eles fomentam as chamadas "decisão de aderência", nas quais o juiz acata integralmente o trabalho do perito, sem sequer citar dados do exame ou fatos da execução que corroboram ou não com o que ficou atestado para melhor sustentar a decisão, consubstanciando-se a solução da causa na prova pericial.

É sabido que a valoração das provas técnicas revela-se atividade mais complexa e árdua que a valoração das outras provas. O desafio repousa no fato de como valorar 
racionalmente o resultado de provas oriundas de conhecimentos que não se detém, já que a realização de uma prova técnica se dá justamente em razão da ausência de determinado conhecimento pelo juiz, necessário para o deslinde do feito.

Infelizmente tornou-se comum em sede de execução da pena que a carga decisória das pretensões do apenado recaia, em suma, nas mãos dos peritos.

Não é incomum constatar que o juiz acolhe acriticamente o laudo pericial, por considerar o que lá está como verdade absoluta, pois não o compreende, o que revela a existência de uma subordinação ao parecer do perito. De outro lado, também se enfrenta situações em que o perito em vez de prestar apenas esclarecimentos teóricos ou gerais que permitirão ao juiz avaliar os fatos, acaba por emitir juízos de valor, que escapam a sua função.

É o que podemos denominar como o fenômeno do "perito julgador", no qual o perito passa a proferir juízos de valores, de difícil refutação pelo magistrado, desconhecedor do método utilizado, tão comum nos perícias criminológicas.

Essa postura deve ser totalmente repudiada, pois o perito deve limitar-se a examinar e avalizar o plano fático, sendo vedado ao experto formular conclusão de ordem jurídica, que é privativa do juiz.

A conclusão do exame criminológico não vincula o juiz, pois é apenas um dos elementos que o juiz valora para atingir o resultado da prova. Trata-se de uma prova relativa e não definitiva, portanto, deve ser cotejada com os demais elementos do acervo probatório.

Ser ou não ratificador da conclusão de exame criminológico depende do próprio magistrado. É necessário que o juiz assuma, na expressão cunhada por José Renato Nalini, a posição de senhor do laudo, avaliando a prova com liberdade, sem sentir-se atrelado, ou intimidado pelas opiniões dos peritos, que, em algumas vezes se revelam confusas, ambíguas, ou impalpáveis.

Ainda que seja prova dotada de cientificidade, o exame criminológico é incapaz de conduzir a uma certeza plena dos fatos, mas apenas a uma aproximação maior ou menor da certeza dos fatos.

Com esta constatação não se visa tirar a credibilidade do exame criminológico ou desencorajar sua elaboração, afinal a procura pela certeza é o que impulsiona a atividade probatória, nesse sentido, deve-se estimular a busca por elementos úteis para confirmar os fatos considerados incertos para auxiliar na formação do convencimento do juiz. No 
entanto, é preciso ter em mente que a verdade que se atingirá com o exame criminológico será necessariamente relativa, uma vez que a verdade judicial será aquela encontrada no conjunto probatório como um todo.

Dadas às conhecidas carências do sistema penitenciário quanto a recursos materiais e humanos, o exame criminológico transformou-se em laudos morosos, lacônicos, superficiais e muitas vezes de conteúdo repetitivo e genérico. Da forma como vem sendo confeccionado o exame criminológico não tem se revelado um meio hábil e imprescindível para fornecer subsídios técnicos para o julgador formar um juízo sobre a conveniência de transferir o sentenciado a um regime menos gravoso e tomar a decisão mais acertada, de maneira a assegurar a efetividade da execução penal e ao mesmo tempo compatibilizar o interesse de reconquista da liberdade pelo condenado com a necessidade de se garantir a segurança social.

O mesmo se aplica ao atestado de boa conduta carcerário tido como substitutivo do exame criminológico na aferição de requisito subjetivo para o alcance de benefícios prisionais.

$\mathrm{O}$ atestado de boa conduta emitido pela diretoria do presídio ainda que seja um critério mais objetivo, não soluciona a questão da apuração do mérito. A semelhança do que acontecia com os exames criminológicos, os atestados de boa conduta são lacônicos, produzidos em escala industrial. Não há fundamentação na manifestação do diretor do presídio que opina genericamente em relação à situação do preso, o que torna os atestados de conduta imprestáveis para a finalidade a qual estão destinados.

Além disso, o atestado de conduta tem sua eficácia probatória contestada, na medida em que não se sabe se a boa conduta aponta um homem regenerado, com condições de ressocialização, ou se revela uma boa adaptação, no sentido pejorativo, à vida carcerária, tratando-se de um homem afetado pela prisionalização.

Apesar de notórias as falhas para a aferição do requisito subjetivo, sustentar a decisão judicial em exames criminológicos e atestados de conduta tornou-se mais cômodo, além de possibilitar a transferência ou compartilhamento de responsabilidade entre juízes e técnicos sobre o condenado reintegrado à sociedade. Caso haja desacerto na decisão que concedeu a promoção, e volte o sentenciado a delinquir, foram os técnicos que erraram e não o juiz, e vice-versa. 
O ideal para a efetiva aferição de que o sentenciado reúne condições adequadas para o retorno da convivência social, seria o juiz dar um olhar mais atento a todo o processo de execução de cada sentenciado sob sua jurisdição. Aproveitando-se, por exemplo, das impressões colhidas durante as idas aos estabelecimentos prisionais, considerando que a exigência legal de visita constante, além da função de fiscalização, implica a participação direta do juiz no cumprimento de pena. E na hipótese de ter requerido o exame criminológico, mediante decisão fundamentada, o magistrado deve avaliar as informações trazidas pelo exame criminológico cotejando-o com os demais dados constantes no processo de execução do sentenciado, procurando verificar se os elementos periciais encontram respaldo nas demais provas produzidas nos autos, principalmente na prova documental (relatório de conduta, boletim informativo, folha de antecedentes), a fim de constatar se as conclusões dos expertos são dotadas de raciocínio, lógico, técnico e científico, sem margens de subjetivismo. 


\section{BIBLIOGRAFIA}

ALBERGARIA, Jason. O juiz de execução penal. Revista do Conselho Nacional de Política Criminal e Penitenciária, Brasília, v.1, n.3, p.41-57, jan./jun. 1994.

BADARÓ, Gustavo Henrique Righi Ivahy. Direito Processual Penal. Rio de Janeiro: Elsevier, 2008.t.I.

Ônus da prova no processo penal. São Paulo: RT, 2003.

BARBIERI, Louri Geraldo. Execução penal: sistema progressivo e mérito do reeducando. Cadernos Jurídicos. Escola Paulista da Magistratura, São Paulo, v.7, n.26, p.98-99 jan./abr. 2006.

BARRETO, Djalma Lúcio Gabriel. Instituição do exame criminológico e suas implicações processuais. Dissertação de mestrado. Faculdade de Direito da USP, São Paulo, 1976.

BARROS, Carmen Silvia de Moraes. A individualização da pena na execução penal. São Paulo:RT, 2001.

As modificações introduzidas no arts. $6^{\circ}$ e 112 da LEP pela lei 10.792/2003 e a jurisdicionalização e a individualização da pena na execução penal. Revista Brasileira de Ciências Criminais, São Paulo, v. 12, n. 48, p. 179-193, mai./jun. 2004.

BENETI, Sidnei Agostinho. Execução penal. São Paulo: Saraiva, 1996.

BESSA, Noeli Kühl Svoboda. Os instrumentos técnicos previstos pela Lei de Execução Penal Brasileira para formalizar a classificação dos condenados e avaliar o requisito subjetivo por ocasião da progressão de regime ou livramento condicional. Direito $e$ Sociedade, Paraná, n.1,v.1, p.207-217, 2000.

BITTENCOURT, Cezar Roberto. Regimes penais e exame criminológico. Revista dos Tribunais, São Paulo, v. 77, n.638, p. 260-269, dez. 1998.

BONFIM, Edilson Mougenot. Curso de processo penal. 5ed, São Paulo:Saraiva, 2010.

CÂMARA, Alexandre Freitas. O escopo da prova pericial e critérios para a escolha do perito. Revista da Associação Brasileira da propriedade intelectual, $\mathrm{n}^{\circ}$ 89, p.13-26, jul/ago 2007.

CAPEZ, Fernando, Curso de Processo Penal, 18ª ed., São Paulo: Saraiva, 2011.

CARVALHO, Salo de. Da necessidade da efetivação do sistema acusatório no processo de execução penal. In: Carvalho, Salo de (org.). Crítica à execução penal. Rio de Janeiro: Lumen Juris, 2007.

O papel da perícia psicológica na execução penal. Psicologia Jurídica no Brasil. 2.ed. Rio de Janeiro: Nau, 2005. 
O (novo) Papel dos "Criminologos" na Execução Penal: As alterações estabelecidas pela Lei 10.792/03. In: Carvalho, Salo de (org.). Crítica à execução penal. Rio de Janeiro: Lumen Juris, 2007.

Práticas Inquisitivas na Execução Penal (Estudo do Vínculo do Juiz aos Laudos Criminológicos a partir da Jurisprudência Garantista do Tribunal de Justiça do RS). In: Carvalho, Salo de (org.). Crítica à execução penal. Rio de Janeiro: Lumen Juris, 2002.

; FREIRE, Christiane Russomano. O Regime Disciplinar Diferenciado: Notas Críticas à Reforma do Sistema Punitivo Brasileiro. In Carvalho, Salo de (org.). Crítica à execução penal. Rio de Janeiro: Lumen Juris, 2007.

CAVALCANTI, Eduardo M.. O ministério público na execução penal. In Carvalho, Salo de (org.). Crítica à execução penal. Rio de Janeiro: Lumen Juris, 2007.

CINTRA, Antonio Carlos de Araújo; GRINOVER, Ada Pellegrini; DINAMARCO Cândido Rangel. Teoria geral do processo, $21^{\text {a }}$ edição, São Paulo: Malheiros, 2004.

CINTRA JUNIOR, Dyrceu Aguiar Dias. A jurisdicionalização do processo de execução penal. Revista Brasileira de Ciências Criminais, São Paulo, v.3, n.9, p.115-132, jan./mar. 1995.

DINAMARCO Cândido Rangel; CINTRA, Antonio Carlos de Araújo; GRINOVER, Ada Pellegrini. Teoria geral do processo, 21 a edição, São Paulo: Malheiros, 2004.

DOTTI, René Ariel. A crise da execução penal e o papel do Ministério Público, Justitia, 47 (129): 34-54, abr/jun.1985.

A lei de execução penal: perspectivas fundamentais. Revista de Política Criminal e Penitenciária, Brasília, v.1, p.239-249, jan./jun.1988.

Processo Penal Executório. Revista dos Tribunais, São Paulo. v.72. n. 576, p.309-322, out. 1983.

EISELE, Andreas. A prova pericial no processo penal e o sistema do livre convencimento motivado. Revista Dialética de Direito Processual, São Paulo, n.1, p.7-22, abr.2003.

FARIAS, Vilson. O exame criminológico na aplicação da pena. Revista Brasileira de Ciências Criminais, São Paulo, v.4, n. 15, p. 269-98, jul./set. 1996.

FERNANDES, Antonio Scarance. Execução penal: aspectos jurídicos. Revista CEJ, Brasília, v. 3, n.7, p.68-83, abr. 1999.

O ministério público na execução penal. In Grinover, Ada Pellegrini; Busana, Dante (coord.). Execução Penal, São Paulo: Max Limonad, 1987. 
Reflexos relevantes de um processo de execução penal jurisdicionalizado. Revista Brasileira de Ciências Criminais, São Paulo, v.1, n.3, p.83-99, jul./set., 1993.

; GRINOVER, Ada Pellegrini; GOMES FILHO, Antonio Magalhães. A exigência de jurisdicionalização da execução. Fascículos de Ciências Penais, Porto Alegre, v.4, n.3, p. 3-21, jul./set. 1991.

FRASSETO, Flávio Américo; NETTO, Alexandre Orsi. Um engodo chamado exame criminológico. Boletim do Instituto Brasileiro de Ciências Criminais, São Paulo, ano 17, n. 209, p. 07-08, abr. 2010.

FREIRE, Christiane Russomano; CARVALHO, Salo de. O Regime Disciplinar Diferenciado: Notas Críticas à Reforma do Sistema Punitivo Brasileiro. In Carvalho, Salo de (org.). Crítica à execução penal. Rio de Janeiro: Lumen Juris, 2007.

FULLER, Paulo Henrique Aranda; JUNQUEIRA, Gustavo Octaviano Diniz. Legislação Penal Especial, 6.ed. São Paulo:Saraiva, 2010.v.1.

GIL, Jorge Raul. Análisis de la figura del juez de ejecución penal. Revista del Colégio de Abogados de la Plata, La Plata, v.44, n.65, p.165-172, dic 2004.

GOMES FILHO, Antonio Magalhães. A defesa do condenado na execução penal. In Grinover, Ada Pellegrini; Busana, Dante (coord.). Execução Penal, São Paulo: Max Limonad, 1987.

O livre convencimento do juiz no Projeto de Código de Processo Penal: primeiras anotações. Boletim do Instituto Brasileiro de Ciências Criminais, n.200,p.08-09, jul. 2009.

Provas - Lei 11.690, de 09.06.2008, in MOURA, Maria Thereza Rocha de Assis (Coord.). As Reformas no Processo Penal. As novas Leis de 2008 e os Projetos de Reforma. São Paulo; RT, 2008.

; GRINOVER, Ada Pellegrini; FERNANDES, Antonio Scarance. A exigência de jurisdicionalização da execução. Fascículos de Ciências Penais, Porto Alegre, v.4, n.3, p. 3-21, jul./set. 1991.

GRINOVER, Ada Pellegrini. Anotações sobre os aspectos processuais da Lei de Execução Penal, in Execução Penal. In Grinover, Ada Pellegrini; Busana, Dante (coord.). Execução Penal, São Paulo: Max Limonad, 1987.

- Natureza Jurídica da execução penal. In Grinover, Ada Pellegrini; Busana, Dante (coord.). Execução Penal, São Paulo: Max Limonad, 1987.

O conteúdo da garantia do contraditório. In Novas tendências do Direito Processual, Rio de Janeiro: Forense Universitária, 1990, p. 17-44.

Prova pericial: conhecimento técnico especializado e perícia complexa. Revista da Associação Brasileira da propriedade intelectual, $\mathrm{n}^{\circ}$ 89, jul/ago 2007, p.3-12. 
; GOMES FILHO, Antonio Magalhães; FERNANDES, Antonio Scarance. A exigência de jurisdicionalização da execução. Fascículos de Ciências Penais, Porto Alegre, v.4, n.3, p. 3-21, jul./set. 1991.

; CINTRA, Antonio Carlos de Araújo Cintra e DINAMARCO Cândido Rangel. Teoria geral do processo, 21 a edição, São Paulo, Revista dos Tribunais, 2004.

GUINDANI, Miriam Krenzinger A. Os (des)caminhos da avaliação criminológica. Revista de Estudos Criminais, Porto Alegre, n.10, v.3, p. 137-146, 2003.

HIGUERA GUIMERÁ, Juan-Felipe. La prueba pericial psiquiátrica em los procedimentos judiciales penales y la medicina forense em España: uma respetuosa llamada urgente de atención. La Ley Penal: revista de derecho penal, procesal y penitenciário, Madrid, n.24.v.3, p.14-36, 2006.

HOENISCH, Julio César Diniz. A Psicologia entre Nuvens e Granito: Problematizando as Perícias Criminais. In Carvalho, Salo de (org.). Crítica à execução penal. Rio de Janeiro: Lumen Juris, 2007.

IENNACO, Rodrigo. A supressão do exame criminológico como (mais um) obstáculo à efetividade da execução penal: revisitando o paradigma behaviorista. Revista dos Tribunais, São Paulo, v.94, n. 838, p. 446-55, ago. 2005.

JARDIM, Afrânio Silva, O ônus da prova na ação penal condenatória. Revista de Processo, São Paulo, n. 47, p. 259-272, jul./set. 1987.

JUNQUEIRA, Gustavo Octaviano Diniz; FULLER, Paulo Henrique Aranda. Legislação Penal Especial, 6.ed. São Paulo:Saraiva, 2010.v.1.

LAGOS, Daniel Ribeiro; MIGUEL, Alexandre. A execução penal: instrumentalização e competência. Revista dos Tribunais, São Paulo, v.82. n..690, p.398-402, abr. 1993.

LAMMÊGO BULOS, Uadi. O livre convencimento do juiz e as garantias constitucionais do processo penal. Revista da EMERJ, Rio de Janeiro, v.3, n.12, p.184-198, 2000.

LEAL, César Barros. A execução penal na América latina e no Caribe: realidade e desafios. Revista Brasileiro de Ciências Criminais, São Paulo, v.12, n.50, p.119-147, set./out. 2004.

LEITE, George Lopes. O papel do juiz na execução penal (mesa redonda IV). Revista CEJ, Brasília, v.5, n.15, p.5-7, dez 2001.

LOPES JUNIOR, Aury. A (im)prestabilidade jurídica dos laudos técnicos na execução penal. Boletim do Instituto Brasileiro de Ciências Criminais, São Paulo, ano 11, n.123, p. 11-13, fev. 2003.

Revisitando o Processo de Execução Penal a partir da Instrumentalidade Garantista. In Carvalho, Salo de (org.). Crítica à execução penal. Rio de Janeiro: Lumen Juris, 2007. 
; FREIRE, Christiane Russomano. O Regime Disciplinar Diferenciado: Notas Críticas à Reforma do Sistema Punitivo Brasileiro. In Carvalho, Salo de (org.). Crítica à execução penal. Rio de Janeiro: Lumen Juris, 2007.

LORENZI, Ricardo. A motivação judicial no âmbito da execução penal. Revista IOB de Direito Penal e Processual Penal, Porto Alegre, v.7, n.42, p.69-9, fev./mar. 2007.

MANZANO, Luís Fernando de Moraes. Prova pericial: admissibilidade e assunção da prova científica e técnica no processo brasileiro. Dissertação de Mestrado. Faculdade de Direito da USP, São Paulo, 2010.

MARCÃO, Renato Flávio. Curso de execução penal, 8.ed. São Paulo: Saraiva, 2010.

. O exame criminológico e a equivocada resolução n009/2010 do Conselho Federal de Psicologia. Revista Magister de Direito Penal e Processual Penal, n.37, v.7, p. 35-38, 2010.

MARQUES, Jader. Exame de classificação e de observação criminológica na execução penal. Ensaios penais em homenagem ao Professor Alberto Rufino Rodrigues de Sousa. Porto Alegre: Ricardo Lenz, p. 375-388, 2003.

MARTINS, Sérgio Mazina. A construção da execução penal em face da doutrina dos direitos humanos: uma conversação histórica. Dissertação de mestrado. Faculdade de Direito da USP, 2002.

MIGUEL, Alexandre; LAGOS, Daniel Ribeiro. A execução penal: instrumentalização e competência. Revista dos Tribunais, São Paulo, v.82. n..690, p.398-402, abr. 1993.

MIRABETE, Julio Fabbrini. Execução penal. 11.ed. São Paulo: Atlas, 2008.

MONTES GIRALDO, Mario. Juez de ejecución de penas en el Estado Constitucional y princípios de favorabilidad, dignidad humana, libertad, igualdad, legalidad, debido proceso y presunción de inocência. Derecho Penal y Criminologia, Bogotá,v.22,n.72, mayo/ago. 2001.

MOURA, Maria Thereza Rocha de Assis, Execução penal e falência do sistema carcerário. Boletim do Instituto Brasileiro de Ciências Criminais, São Paulo, ano 7, n. 83, p.10, out. 1999.

NALINI, José Renato. Pode o juiz melhorar a execução penal?. In Lagrasta Neto, Caetano; Nalini, José Renato; Dip, Ricardo Henry Marques (coord.). Execução penal - visão do TACRIM-SP. São Paulo: Oliveira Mendes, 1998.

NETTO, Alexandre Orsi. A falácia do in dúbio pro societate como princípio no processo de execução criminal. Boletim do Instituto Brasileiro de Ciências Criminais, São Paulo, ano 17, n. 204, p. 14-15, nov., 2009.

NETTO, Alexandre Orsi; FRASSETO, Flávio Américo. Um engodo chamado exame criminológico. Boletim do Instituto Brasileiro de Ciências Criminais, São Paulo, ano 17, n. 209, p. 07-08, abr. 2010. 
NIESS, Pedro Henrique Távora, O ônus da prova no processo civil e no processo penal, Justitia, v.118, p. 192-206 set./out. de 1982.

NUCCI, Guilherme de Souza. Leis Penais e Processuais Penais Comentadas. 2.ed. São Paulo: RT, 2007.

. Manual de Processo Penal e Execução Penal, 3.ed. São Paulo: RT, 2007.

Provas no processo penal, $2^{\mathrm{a}}$ edição, São Paulo:RT, 2011.

PASSOS, Josue Modesto; WEINTRAUB, Arthur Bragança de Vasconcellos. O direito de execução penal brasileiro: uma análise a luz do pensamento criminológico. Revista Brasileira de Ciências Criminais, São Paulo, v.6, n.23, p.155-170, jul./set.1999.

PIMENTEL, Manoel Pedro. Sistemas penitenciários, Revista dos Tribunais. São Paulo. v.78. n.. 639, p.265-274, jan. 1988.

PITOMBO, Sérgio Marcos de Moraes. Execução Penal. Revista de Política Criminal e Penitenciária, Brasília, v.1, n.1, p.215-25, jan/jun. 1988.

Os regimes de cumprimento de penas e o exame criminológico. Revista dos Tribunais. v.73, n.583, p. 312-315, maio 1984.

PRADO, Fabiana Lemes Zamalloa. Execução penal e garantismo: as alterações introduzidas na lei de execuções penais sobre o exame criminológico. Boletim do Instituto Brasileiro de Ciências Criminais, São Paulo, n.146, p.06-08, jan. 2005.

RODRIGUES, Rubens. A Execução penal como instrumento de formulação de políticas preventivas criminais. A Força Policial, São Paulo, n.27, p.5-19, jul./set. 2000.

SÁ, Alvino Augusto de. Criminologia Clínica e Psicologia Criminal. São Paulo: RT, 2007.

Equipe criminológica: convergências e divergências. Revista Brasileira de Ciências Criminais, São Paulo, n.2, p. 41-45, 1993.

O exame criminológico e seus elementos essenciais, Boletim do Instituto Brasileiro de Ciências Criminais. São Paulo, ano18, n. 214, p. 04-05, set., 2010.

Os três instrumentos de avaliação dos apenados na legislação penal brasileira. Justiça e Democracia, Cotia, n.3, p.163-169, 1997.

SANTOS, Eduardo Pereira. Execução Criminal. Revista Brasileira de Ciências Criminais, São Paul, v.9, n.38, p.107-119, abr/jun, 2002.

SCAPINI, Marco Antônio Bandeira. Execução penal - Controle da legalidade. Revista CEJ, Brasília,v.5, n.15, p.51-63, dez. 2001. 
SCHMIDT, Andrei Zenkner, Hermenêutica na execução penal. Revista Brasileira de Ciências Criminais, São Paulo, v.9, n.38, p.84-121, abr/jun, 2002.

- Crônica acerca da extinção do exame criminológico. Boletim do Instituto Brasileiro de Ciências Criminais, São Paulo, n.134, p.02-03, jan.2004.

SILVA, Haroldo Caetano da. O exame criminológico e a oportuna resolução no009/2010 do Conselho Federal de Psicologia. Revista Magister de Direito Penal e Processual Penal, n.37, v.7, p.39-41, 2010.

SILVA, Marco Antonio Marques da. A Vinculação do Juiz no Processo de Penal. São Paulo: Saraiva, 1993.

SOUZA, Paulo Sergio Xavier de. A vinculação do juiz ao exame criminológico. Justiça e Sociedade, Revista Jurídica da FCJAC-UNOESTE, Presidente Prudente, v. 1, n.2, p. 27085, dez., 1999.

SWENSSON, Walter. A competência do juízo da execução. In Lagrasta Neto, Caetano; Nalini, José Renato; Dip, Ricardo Henry Marques (coord.). Execução penal - visão do TACRIM-SP. São Paulo: Oliveira Mendes, 1998

TARUFFO, Michele.Conoscenza scientifica e decisione giudiziaria: profili generali, em Queaderni Della Rivista trimestrale di Diritto e procedura civile. Decisione giudiziaria e verità scientifica, Guiffrè, Milano, n.8, pp. 03-23, 2005.

TEIXEIRA, Alessandra. Do sujeito de direito ao Estado de Exceção: o percurso contemporâneo do sistema penitenciário brasileiro. Dissertação de mestrado. Faculdade de Filosofia, Letra e Ciências Humanas da USP, 2006.

THEODORO JÚNIOR, Humberto. Admissibilidade da prova pericial complexa. Direito à prova e garantias processuais constitucionais. Revista da Associação Brasileira da propriedade intelectual, n. 89, p.63-71, jul/ago 2007.

WEINTRAUB, Arthur Bragança de Vasconcellos; PASSOS, Josue Modesto. O direito de execução penal brasileiro: uma análise a luz do pensamento criminológico. Revista Brasileira de Ciências Criminais, São Paulo, v.6, n.23, p.155-170, jul./set.1999.

ZILLI, Marcos Alexandre Coelho. A iniciativa instrutória do Juiz no processo Penal. São Paulo:RT, 2003. 